\title{
Pre-Clinical and Clinical Applications of Small Interfering RNAs (siRNA) and Co-Delivery Systems for Pancreatic Cancer Therapy
}

\author{
Sepideh Mirzaei ${ }^{1,+}$, Mohammad Hossein Gholami ${ }^{2,+}$, Hui Li Ang ${ }^{3,+}$, Farid Hashemi ${ }^{4}$, Ali Zarrabi ${ }^{5}$, \\ Amirhossein Zabolian ${ }^{6}$, Kiavash Hushmandi ${ }^{7}$, Masoud Delfi ${ }^{8}$, Haroon Khan ${ }^{9}$, Milad Ashrafizadeh ${ }^{10,11, *}$, \\ Gautam Sethi ${ }^{12,13, *}$ and Alan Prem Kumar $3,12,13, *$ (D)
}

check for updates

Citation: Mirzaei, S.; Gholami, M.H.; Ang, H.L.; Hashemi, F.; Zarrabi, A.; Zabolian, A.; Hushmandi, K.; Delfi, M.; Khan, H.; Ashrafizadeh, M.; et al. Pre-Clinical and Clinical Applications of Small Interfering RNAs (siRNA) and Co-Delivery Systems for Pancreatic Cancer Therapy. Cells 2021, 10, 3348. http://doi.org/10.3390/ cells10123348

Academic Editor: Paola Cappello

Received: 8 November 2021

Accepted: 17 November 2021

Published: 29 November 2021

Publisher's Note: MDPI stays neutral with regard to jurisdictional claims in published maps and institutional affiliations.

Copyright: (C) 2021 by the authors. Licensee MDPI, Basel, Switzerland. This article is an open access article distributed under the terms and conditions of the Creative Commons Attribution (CC BY) license (https:/ / creativecommons.org/licenses/by/ $4.0 /)$.
1 Department of Biology, Faculty of Science, Islamic Azad University, Science and Research Branch, Tehran 1477893855, Iran; sepidehmirzaei.smv@gmail.com

2 Faculty of Veterinary Medicine, Kazerun Branch, Islamic Azad University, Kazerun 7319866451, Iran; hoseingholami2020@yahoo.com

3 Cancer Science Institute of Singapore and Department of Pharmacology, Yong Loo Lin School of Medicine, National University of Singapore, Singapore 117599, Singapore; e0336095@u.nus.edu

4 Department of Comparative Biosciences, Faculty of Veterinary Medicine, University of Tehran, Tehran 1419963114, Iran; faridhashemi172@gmail.com

5 Department of Biomedical Engineering, Faculty of Engineering and Natural Sciences, Istinye University, Sariyer, Istanbul 34396, Turkey; alizarrabi@sabanciuniv.edu

6 Resident of Orthopedics, Department of Orthopedics, School of Medicine, 5th Azar Hospital, Golestan University of Medical Sciences, Golestan 4934174515, Iran; ah_zabolian@student.iautmu.ac.ir

7 Department of Food Hygiene and Quality Control, Division of Epidemiology, Faculty of Veterinary Medicine, University of Tehran, Tehran 1419963114, Iran; houshmandi.kia7@ut.ac.ir

8 Department of Chemical Sciences, Complesso Universitario Monte S. Angelo, University of Naples "Federico II", 80126 Naples, Italy; masouddelfi51@gmail.com

9 Department of Pharmacy, Abdul Wali Khan University, Mardan 23200, Pakistan; haroonkhan@awkum.edu.pk

10 Faculty of Engineering and Natural Sciences, Sabanci University, Orta Mahalle, Üniversite Caddesi No. 27, Orhanl1, Tuzla, Istanbul 34956, Turkey

11 Sabanci University Nanotechnology Research and Application Center (SUNUM), Tuzla, Istanbul 34956, Turkey

12 Department of Pharmacology, Yong Loo Lin School of Medicine, National University of Singapore, Singapore 117600, Singapore

13 NUS Centre for Cancer Research (N2CR), Yong Loo Lin School of Medicine, National University of Singapore, Singapore 119228, Singapore

* Correspondence: milad.ashrafizadeh@sabanciuniv.edu (M.A.); phcgs@nus.edu.sg (G.S.); apkumar@nus.edu.sg (A.P.K.)

+ These authors have participated equally in manuscript.

Abstract: Pancreatic cancer (PC) is one of the leading causes of death and is the fourth most malignant tumor in men. The epigenetic and genetic alterations appear to be responsible for development of PC. Small interfering RNA (siRNA) is a powerful genetic tool that can bind to its target and reduce expression level of a specific gene. The various critical genes involved in PC progression can be effectively targeted using diverse siRNAs. Moreover, siRNAs can enhance efficacy of chemotherapy and radiotherapy in inhibiting PC progression. However, siRNAs suffer from different off target effects and their degradation by enzymes in serum can diminish their potential in gene silencing. Loading siRNAs on nanoparticles can effectively protect them against degradation and can inhibit off target actions by facilitating targeted delivery. This can lead to enhanced efficacy of siRNAs in PC therapy. Moreover, different kinds of nanoparticles such as polymeric nanoparticles, lipid nanoparticles and metal nanostructures have been applied for optimal delivery of siRNAs that are discussed in this article. This review also reveals that how naked siRNAs and their delivery systems can be exploited in treatment of PC and as siRNAs are currently being applied in clinical trials, significant progress can be made by translating the current findings into the clinical settings. 
Keywords: pancreatic cancer; small interfering RNA (siRNA); drug resistance; co-delivery; nanoparticles

\section{Introduction}

Despite advances in various treatment modalities, pancreatic cancer (PC) still remains an incurable disease. The incidence rate of PC has shown an increase and prognosis of patients is not favorable [1,2]. Based on new estimates, PC is the fourth most leading cause of cancer related death [3]. PC patients lack typical early symptoms and they are mainly diagnosed in advanced stages. In fact, there are no specific markers and symptoms for diagnosis of PC patients in early stages and that is why these patients are diagnosed in advanced stages, when cancer cells are not completely responsive to therapy. Although surgery is a potential strategy in PC therapy, as patients are generally diagnosed during local progression or distant metastasis, it is impossible to eradicate PC by surgery [4]. The 5year survival rate for PC is less than 9\%, therefore showing fatality of this cancer [5]. Despite many efforts in providing a novel and effective therapeutic for PC, survival rate of PC patients in last 40 years have not undergone significant improvement [6]. These statements demonstrate that scientists have not been successful in developing an efficient therapeutic against PC. One of the reasons for this failure is that there are a variety of signaling networks participating in cancer progression along with a few other oncogenic pathways that have not been identified yet [7-13]. Furthermore, currently applied therapies are not successful in eradicating cancer. For instance, anti-tumor compounds, often suffer from poor bioavailability $[14,15]$. This restricts their ability in suppressing cancer proliferation and metastasis. Moreover, genetic tools such as CRISPR/Cas9 and small interfering RNA (siRNA), despite their ability to facilitate gene silencing and inhibit cancer progression are unable to completely kill cancer cells [16-19]. This is due to presence of some limitations including their off-targeting feature, their degradation in blood circulation and other impediments such as blood-brain barrier (BBB) and blood-tumor barrier (BTB) [20-24]. Based on these facts, scientists should direct their efforts toward cancer therapeutics that are effective under both in vitro and in vivo conditions and then, such results can be translated into clinical settings for the treatment of cancer patients. To overcome aforementioned problems, there have been efforts in using methods for improving efficacy of drugs and genetic tools for cancer suppression. One of the most beneficial and wellknown ways is using nanocarriers for cancer therapy [25]. In field of gene therapy, gene editing tools such as siRNA and CRISPR/Cas9 systems can be loaded on nanostructures to enhance their intracellular accumulation and prevent off-targeting feature and serum degradation [26-30]. Different nanoarchitectures can be applied for this purpose including carbon quantum dots [31], polymeric nanoparticles [32], lipid nanoparticles [33] and metal nanoparticles [34].

The present review focuses on the potential applications of siRNAs in treatment of PC based on pre-clinical studies. In vitro studies confirm the possible role of naked siRNA in suppressing PC progression via down-regulating tumor-promoting genes such as NUF2, Survivin, RAP80, HIF-1 $\alpha$ and $h T E R T$. However, efficacy of siRNA decreases markedly in vivo, but it is still capable of reducing gene expression of key genes. Based on the experiments, siRNAs can decrease growth and metastasis of PC cells and promote their sensitivity to therapy. Noteworthy, various kinds of nanostructures including micelles, liposomes, carbon-based nanomaterials and dendrimers among others have been used for delivery of siRNAs and in promoting their potential for gene down-regulation in PC treatment. These topics are discussed in the current review article. Furthermore, our review also emphasizes on the different molecular pathways that have been not extensively discussed in previous articles. Moreover, outline of our article is novel and is different from other reviews in this field [35-41]. 


\section{SiRNAs: From Basic to Application in Cancer Therapy}

siRNA as a key strategy of RNA interference (RNAi) is of importance in field of cancer therapy due to its potential in down-regulating expression of oncogenes [42]. siRNA molecules are double-stranded oligonucleotides with length of 20-25 base pairs capable of stimulating messenger RNA (mRNA) degradation and reducing gene expression [43]. The process of mRNA degradation is a little complex [44]. Although a variety of RNA degradation pathways have been identified, the basics of RNA degradation in bacteria, archaea and eukeryotic cells are similar [45]. Overall, there are three categories of enzymes capable of mediating RNA degradation including A) endonucelases with capacity of RNA degradation internally, $5^{\prime}$ exonucleases that can cut RNA from $5^{\prime}$ end to $3^{\prime}$ exonucleases that can cut RNA from $3^{\prime}$ end [46,47]. For the purpose of RNA degradation, siRNA is embedded to RNA-induced silencing complex (RISC) that also contains Argonaute protein (Ago-2) with ability of cleaving and eliminating passenger strand of siRNA duplex. RISC complex in accompany with single stranded guide RNA can recognize targeted mRNA via complementary base pairing [48,49]. Then, Ago-2 degrades mRNA complementary to antisense strand to provide nucleolytic cleavage to $5^{\prime}$ end of antisense siRNA strand (Figure 1) [50-54].
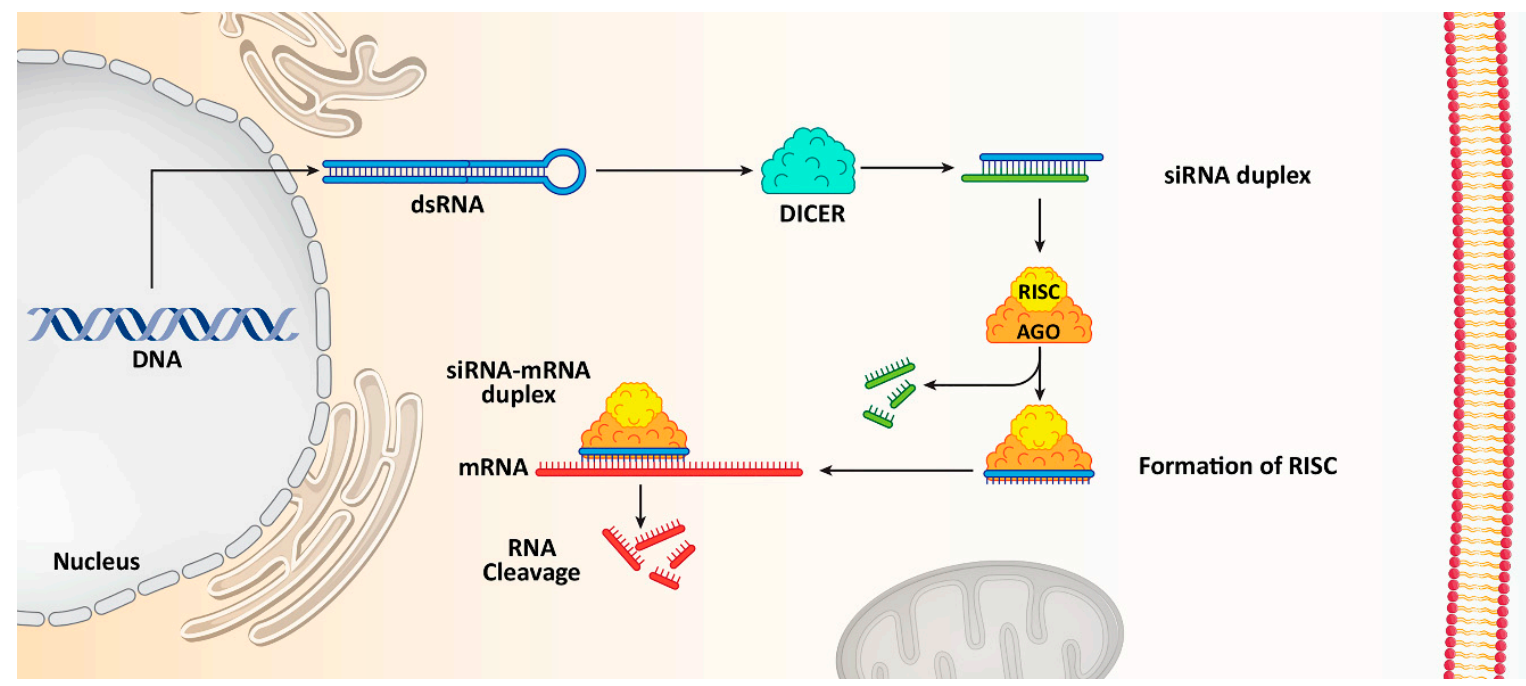

Figure 1. The functions of siRNA in reducing gene expression and causing mRNA cleavage.

Currently, siRNAs can serve as powerful tool that scientists use in cancer therapy. Following identification of signaling networks responsible for cancer malignancy, siRNAs can be developed for targeting them. To date, a variety of studies have evaluated potentiality of siRNAs in gene silencing both in vitro and in vivo. For instance, Bcl-2 is an anti-apoptotic factor that its up-regulation is in favor of glioblastoma growth and viability. Using siRNA significantly diminishes Bcl-2 expression to induce apoptosis in glioblastoma cells, and promote their sensitivity to taxol chemotherapy [55]. Noteworthy, co-application of siRNA with anti-tumor compounds can exhibit synergistic anti-cancer effects. The CD73-siRNA is able to impair proliferation and progression of tumor cells that are of importance for enhancing doxorubicin sensitivity [56]. The Bcl-2-siRNA induces apoptotic cell death and reverses doxorubicin resistance in hepatocellular carcinoma [57]. The same strategy has been used for cisplatin sensitivity, such that using GPX4-siRNA and ABCC3-siRNA can induce drug sensitivity in glioblastoma and lung tumors, respectively [58,59]. Tumor-promoting factors such as poly (ADP-ribose) polymerase (PARP) and endothelial cell-specific molecule-1 (ESM-1) can be down-regulated by siRNA in suppressing proliferation and migration of cancer cells, respectively $[60,61]$.

Low toxicity and high efficiency are potential benefits of siRNA [62,63]. However, siRNAs are associated with several limitations that should be addressed. Despite promis- 
ing results in vitro [64], it has been found that siRNAs are not quite successful in causing gene silencing in vivo. More investigations have revealed that siRNAs could be degraded by RNase enzymes present in the serum [65]. They cannot sufficiently penetrate cell membrane, requiring nanocarriers for its delivery. Finally, their off-targeting feature can be overcome by using nanostructures and providing targeted delivery. Application of nanocarriers created a significant progress in gene silencing and cancer therapy, as intracellular accumulation of siRNA is improved, it is protected against degradation and its off-targeting effects are removed [66-71]. That is why experiments have been directed towards using nanoparticles for delivery of siRNAs in cancer therapy [72-75]. Polymeric nanoparticles [76], micelles [77], dendrimer [78], liposome [78], exosome [79], silicon-lipid nanoparticles [80] and cationic nanoemulsions [81] have been applied for delivery and controlled release of siRNA in cancer therapy. A recent experiment has used selenium nanostructures for delivery of Derlin1-siRNA in cervical cancer treatment. For enhancing selectivity of selenium nanoparticles toward tumor cells, its functionalization with RGDfC peptide has been performed. The RGDfC-modified selenium nanoparticles penetrate into cervical cancer cells via clathrin-mediated endocytosis and release siRNA in a sustained manner. These siRNA-loaded nanoparticles can suppress cervical cancer progression via inducing apoptosis and impairing mitochondrial function [82]. The arginine-modified calcium phosphate nanoparticles have been used for siRNA delivery and reducing expressin levels of survivin and cyclin B1 that is of importnace in sensitizing lung cancer cells to apoptosis [83]. Redox-responsive nanoparticles as smart nanocarriers have been developed for EGFR- and BRD4-siRNA delivery. Redox-sensitive nanoparticles have been modified with peptides to promote their internalization in cells and effectively suppress breast cancer progression [84]. The encapsulation efficiency of nanoparticles seems to be up to $95 \%$ [85] and they can mediate chemosensitivity via co-delivery of siRNA (KRAS) and anti-tumor drugs (gemcitabine) [86]. In the following sections, a mechanistic and in-depth discussion of using various siRNAs in PC therapy is provided. Table 1 summarizes some of the clinical trials for applications of siRNAs in cancer therapy.

Table 1. Clinical trials using siRNAs in the treatment of cancer patients.

\begin{tabular}{|c|c|c|c|c|}
\hline siRNA & Cnacer Type & Phase & Aim & Trial Number \\
\hline Atu027 & $\begin{array}{l}\text { Advanced solid } \\
\text { tumors }\end{array}$ & Phase I & $\begin{array}{l}34 \text { participants that receive eight } \\
\text { treatments within } 4 \text { weeks } \\
\text { The aim is to determine best and } \\
\text { optimal dose in cancer treatment }\end{array}$ & NCT00938574 \\
\hline EphA2 & $\begin{array}{l}\text { Advanced or } \\
\text { recurrent solid } \\
\text { tumors }\end{array}$ & Phase I & $\begin{array}{l}\text { The EphA2 leads to cancer } \\
\text { growth and progression } \\
\text { siRNA targeting EphA2 paves } \\
\text { way in cancer treatment } \\
\text { Determing dose and side effects }\end{array}$ & NCT01591356 \\
\hline CALAA-01 & Solid tumors & Phase I & $\begin{array}{l}\text { Determing pharmacokinetics } \\
\text { and safety profile }\end{array}$ & NCT00689065 \\
\hline PLK1 & Liver cancer & Phase I & $\begin{array}{l}\text { Testing a new drug, known as } \\
\text { TKM-080301 that is a liposomal } \\
\text { nanoformulation containing } \\
\text { siRNA-PLK1 in cancer treatment }\end{array}$ & NCT01437007 \\
\hline $\begin{array}{l}\text { siRNA taregting im- } \\
\text { munoproteasome }\end{array}$ & Melanoma & Phase I & $\begin{array}{l}\text { The aim is to improve anti-tumor } \\
\text { immunity and prevent immune } \\
\text { evasion of cancer cells }\end{array}$ & NCT00672542 \\
\hline MYC & $\begin{array}{l}\text { Solid tumors } \\
\text { Lymphoma } \\
\text { Multiple myeloma }\end{array}$ & Phase I & $\begin{array}{c}\text { Encapsulation of siRNA-MYC by } \\
\text { lipid nanoparticlesin cancer } \\
\text { therapy }\end{array}$ & NCT02110563 \\
\hline PD-L1/PD-L2 & $\begin{array}{l}\text { Heamtological } \\
\text { malignancies }\end{array}$ & $\begin{array}{l}\text { Phase I } \\
\text { Phase II }\end{array}$ & $\begin{array}{l}\text { Developing a new vaccine and } \\
\text { mediating immunotherapy }\end{array}$ & NCT02528682 \\
\hline
\end{tabular}




\section{SiRNA and Pancreatic Cancer Therapy}

\subsection{Proliferation and Growth}

The uncontrolled growth of PC cells makes it difficult to manage this life-threatening disease. Several different factors and pathways are responsible for rapid proliferation of PC cells. A number of recent studies have focused on various oncogenic signaling networks involved in the progression of PC cells. For instance, pancreatic stellate cells are able to secrete exosomes containing miRNA-5703 to induce PI3K/Akt signaling and promote PC growth rate [87]. For example, $\beta$-catenin is another pathway whose up-regulation by Mind Bomb 1 leads to PC growth [88]. On the other hand, tumor-suppressor factors such as miRNA-573 suppress PC growth via TSPAN1 down-regulation [89]. Hence, the process of PC growth seems to be complicated and each gene can target various downstream targets to modulate PC progression [90]. The aim of current section is to show that how siRNAs can be applied in targeting pathways related to the aberrant growth of PC cells.

Precursor of nerve growth factor (proNGF) is a new and potential therapeutic target in cancer therapy. ProNGF expression undergoes up-regulation in PC and mediates metastasis of tumor cells. The lncRNA OIP5-AS1 enhances ProNGF expression via down-regulating miRNA-186-5p expression to increase PC invasion [91]. On the other hand, anoikis is a kind of apoptotic response stimulated by loss of adhesion to substrate. Reversing anoikis resistance is of importance in PC therapy [92]. Furthermore, proNGF can induce anoikis resistance $[93,94]$. In another study, it was found that proNGF-siRNA promotes anoikis induction in PC cells, and significantly reduces their proliferation. Following proNGF down-regulation by siRNA, autophagy inducers including autophagy-related gene 5 (ATG5) and Beclin-1 can undergo inhibition, thereby showing that apoptosis induction and autophagy inhibition can occur by proNGF-siRNA [95]. This study provides new insight about siRNA capacity in affecting interaction among programmed cell death (PCD) pathways. The apoptosis and autophagy interaction can be considered a determining factor in cancer. Inhibiting pro-survival autophagy can sensitize tumor cells to apoptosis [96-98]. The previous study clearly revealed that proNGF-siRNA could be beneficial in apoptosis induction via preventing autophagy [95].

NUF2 (NUF2 Component of NDC80 Kinetochore Complex) is a linker between kinetochore attachment site and tubulin subunits [99]. It has been reported that NUF2 downregulation by RNAi leads to an impairment in attachment of kinetochore to spindle microtubules and can effectively suppress cell proliferation at prometaphase [100]. In vitro and in vivo experiments have shown that NUF2 down-regulation by siRNA leads to decreased PC cell growth. Colony formation was stopped and cell cycle arrest at G0/G1 phase occurs due to down-regulation of cyclin B1, Cdc2 and Cdc25A [101].

Receptor-associated protein 80 (RAP80) shows overexpression in PC and can mediate its progression as well as proliferation [102]. RAP80 is involved in DNA repair process via binding to BRCA1 and recruiting it to DNA damage sites [103-108]. Therefore, RAP80siRNA can be of significant importance in reducing PC proliferation. In this case, RAP80 down-regulation by siRNA can lead to apoptosis induction via Bax up-regulation and Bcl-2 down-regulation. Caspase-8 as an executor of apoptosis was stimulated, while no changes were observed in survivin levels [109]. One of the features of cancer cells is their hypoxic microenvironment that facilitates their progression and malignancy. Hypoxia inducible factor- $1 \alpha$ (HIF-1 $\alpha$ ) up-regulation is responsible for immunosuppression [110], radio-resistance [110], chemoresistance (gemcitabine) [111] and proliferation (Warburg effect) [112] in PC. HIF-1 $\alpha$-siRNA leads to a decrease in mRNA and protein levels of HIF$1 \alpha$ that can remarkably diminish the proliferation and induce apoptosis in PC cells [113]. Therefore, using siRNA can act as a potential strategy in suppressing PC proliferation [114]. Cell cycle arrest and apoptosis induction are major outcomes of targeting tumor-promoting factors by siRNA in PC therapy [115].

SnoN gene is a key member of Skt family with tumor-promoting role. This gene was first recognized due to its similarity in sequence with v-Ski and further investigation revealed that SnoN could induce growth of chicken and quail embryo fibroblasts [116,117]. 
The overexpression of SnoN occurs in human cancers that may result from gene amplification, transcriptional activation and enhanced protein stability [118-120]. In respect to the involvement of SnoN in cancer survival, its down-regulation can be considered to be a promising strategy in PC therapy. Therefore, siRNA has been introduced into PC cells for down-regulating $S n o N$ gene expression. Upon SnoN down-regulation, PC cells undergo apoptosis, and their proliferation was interrupted [121]. It appears that anti-apoptotic proteins can be directly affected for triggering apoptosis in PC cells, instead of targeting molecular pathways that can promote PC progression. For instance, in mitochondrial pathway of apoptosis, the expression of Bcl-2 as an anti-apoptotic factor decreases. Overexpression of Bcl-2 protects cancer cells against cell death. By introducing Bcl-2-siRNA into PC cells, apoptosis can be induced [122]. The interesting point is that a variety of molecular pathways can result in increased proliferation and survival of PC cells. Nek2 is a serine-threonine kinase with potential role in both splitting centrosome and spindle formation in mammalian cells [123]. Nek2 up-regulation provides chromosome instability and aneuploidy in cancers [124]. The Nek2 inhibition appears to be advantageous in decreasing expression level of PD-L1 to enhance lymphocyte infiltration and promote anti-tumor immunity in PC suppression [125]. Hence, targeting Nek2 is of importance in suppressing cancer progression. For this reason, Nek2-siRNA has been applied for PC suppression in vitro and in vivo. Moreover, in mouse model of PC, siRNA has been introduced via a catheter. The Nek2-siRNA can impair the proliferation of PC cells and it promotes survival of xenograft mouse model. Furthermore, Nek2-siRNA can prevent liver metastasis of PC cells [126].

In addition, it has been reported that RPL1, as a ribosomal protein can be targeted in PC therapy. Moreover, down-regulation of RPL1 by siRNA leads to apoptosis and cell cycle arrest at G1 phase, and suppress DNA replication [127]. These studies advocated the fact that first step in PC therapy is identifcation of the various tumor-promoting factors. Thus, siRNAs can be designed for specific targeting of tumor cells to suppress PC proliferation and induce apoptosis [128].

Mammalian histone deacetylases (HDAC) are grouped into four different categories (I-IV) $[129,130]$. They participate in regulating biological processes including chromatin remodeling, gene repression, regulating cell cycle, and differentiation [129,131-133]. HDAC dysregulation is associated with transcription repression and inhibiting expression of tumor-suppressor genes [134,135]. HDAC1 plays a significant role in PC progression. It has been shown that HDAC1 down-regulation can lead to cancer proliferation suppression [136]. HDAC1 and HIF- $1 \alpha$ can produce a complex in binding to hypoxia response elements (HRE) on the miR-548an promoter, down-regulating its expression and enhancing carcinogenesis in PC [137]. HDAC1 recruitment can lead to PC metastasis via reducing E-cadherin levels [138]. It has been established that HDAC1 undergoes up-regulation in PC tissues compared to normal ones. The expression of HDAC1 in PC tissues was $56.4 \%$, while this expression was reduced significantly to $6.7 \%$ in the normal tissues. HDAC1-siRNA leads to down-regulation of this tumor-promoting factor, therefore paving the way for up-regulation of p21 and Bax in apoptosis induction in PC [139].

These studies highlighted the fact that most effective strategy for reducing proliferation rate and viability of PC cells is to affect PCD pathway, especially apoptosis activation that was discussed previously. Furthermore, autophagy is another important form of PCD that can exhibit both pro-survival and pro-death functions in cancers and inhibiting prosurvival autophagy can boost apoptosis induction in PC cells. The siRNAs have been used for down-regulating expression levels of proNGF, NUF2, RAP80, HIF- $1 \alpha$ and SnoN to effectively impair the growth of PC cells and induce apoptosis. There are several other oncogenic pathways involved in PC progression including Wnt/ $\beta$-catenin, STAT3 and NF- $\mathrm{kB}$ that can be focus of future studies. 


\subsection{Metastasis and Angiogenesis}

The previous section clearly demonstrated that growth rate of PC cells is high and related molecular pathways can be targeted by siRNAs to effectively impair PC proliferation. Based on these previously reported studies, there are also several potential mechanisms involved in enhancing metastasis of PC cells that their targeted modulation can be advantageous in tumor treatment. The stimulation of MAPK/ERK axis by A-Raf was found to be vital in elevating migration of PC cells [140]. Furthermore, interactions occurring in tumor microenvironment can lead to PC metastasis. The recruitment of macrophages and their M2 polarization can secrete IL-6 that subsequently can induce STAT3 signaling for promoting PC migration and invasion via EMT induction [141]. STAT3 signaling can stimulate the growth and proliferation of cancer cells [142-144]. Both Akt and ERK1/2 molecular pathways can participate in PC metastasis and their stimulation occurs by FGF19 [145]. The metformin administration, as anti-tumor agent, substantially can reduce HNF4G expression via AMPK up-regulation to impair metastasis of PC cells [146]. Hence, PC migration is an increasing challenge and can significantly promotes aggressiveness of PC cells [147]. This section has been allocated to discuss application of siRNAs in disrupting PC invasion.

Cyclooxygenase-2 (COX-2) is an enzyme involved in the metabolic process of arachidonic acid that can actively participate in carcinogenesis [148-150]. COX-2 induces angiogenesis in PC through up-regulating epidermal growth factor receptor (EGFR) [151]. COX-2 overexpression demonstrates poor prognosis in PC patients [152]. COX-2 inhibitors have been applied in PC therapy due to their efficacy in angiogenesis inhibition via vascular endothelial growth factor (VEGF) down-regulation and suppressing growth $[153,154]$. COX-2-siRNA can trigger apoptosis and cell cycle arrest in PC cells. In tumor xenografts, COX-2-siRNA can significantly attenuate volume and weight of tumors, thus showing the efficiency of gene silencing in vivo [155].

One of the potential therapeutic targets in cancer therapy is c-Src, an important nonreceptor protein tyrosine kinase. Increasing evidence demonstrates tumor-promoting role of c-Src in cancer [156-158]. It can promote carcinogenesis via glycolysis induction [159]. Cell adhesion molecule 1 (CADM1) as a tumor-suppressor, can down-regulate expression of c-Src in suppressing colon tumorigenesis [160]. The self-renewal capacity of breast cancer cells is also regulated by c-Src [161]. These studies highlight the role of c-Src, as a tumor-promoting factor. It seems that c-Src down-regulation by siRNA impairs progression of PC cells via inhibiting angiogenesis. The activation of angiogenesis can occur by EGFR up-regulation, a process involved in cancer metastasis and migration to the distant sites [162-164]. The transfection efficiency of siRNA in PC cells was more than $90 \%$ and expression of c-Src was reduced by $86.1 \%$. Following c-Src down-regulation by siRNA, the expression of VEGF was inhibited, thus suppressing angiogenesis and cancer progression [165].

Although there have been efforts in using siRNA for reducing migration of PC cells and various factors such as COX-2 and c-Src have been affected, there is still a long way before naked siRNAs can be applied for regulating PC progression. There are several other factors such as EMT and matrix metalloproteinases (MMPs) that can also lead to metastasis of PC cells. However, there are no studies reported about using siRNAs for modulating their upstream regulators such as ZEB1/2, TGF- $\beta$ and Snail, among others.

\subsection{Immune Regulation}

Transforming growth factor- $\beta$ (TGF- $\beta$ ) is considered as a novel target in cancer therapy $[166,167]$. Under physiological conditions, TGF- $\beta$ regulates proliferation, differentiation, survival and cell adhesion to preserve tissue homeostasis. In cancer cells, TGF- $\beta$ acts as a positive factor for metastasis via EMT induction [168-170]. On the other hand, retinoic acid-inducible gene I (RIG-I) is affected in cancer immunotherapy by enhancing the levels of interferon and apoptosis induction [171-173]. A bifunctional siRNA for down-regulating TGF- $\beta$ and enhancing RIG-I expression has also been designed. This improvement in function can be obtained by introducing triphosphate group at the $5^{\prime}$ 
end of siRNA. Following TGF- $\beta$ down-regulation, an increase occurs in survival time of xenograft models and metastasis and invasion of PC cells undergo down-regulation. Due to RIG-I activation, immune system can be activated that can promote the levels of interferon and RIG-I and induce apoptosis [174]. In addition, TGF- $\beta$ down-regulation and RIG-I up-regulation increase potential of cancer immunotherapy [175]. However, an experiment has only investigated role of siRNA in cancer immunotherapy and as immune evasion is a common phenomenon in PC [176], more studies are required to show how such genetic tools can be employed in PC treatment and activating anti-tumor immunity. Although only TGF- $\beta$ signaling has been targeted in improving anti-tumor immunity in PC, there is another well-known molecular pathway, known as PD-L1/PD-1 axis that is involved in triggering immune evasion [177]. Hence, further experiments can focus on using siRNA for down-regulating PD-1 expression and promoting anti-tumor immunity against PC cells.

\subsection{Therapy Response and Synergistic Therapy}

Another potential of siRNAs lies in improving potential of chemotherapeutic agents in suppressing tumor progression $[178,179]$. Therefore, combination cancer therapy with siRNA-anticancer drug could be designed. For instance, L-ascorbate is not capable of preventing PC migration. Co-application of siRNA-HIF- $1 \alpha$ and L-ascorbate resulted in ansynergistic effect in suppressing PC invasion [180]. This study demonstrated that siRNA could serve as a potential adjuvant for promoting anti-tumor activity of compounds in PC therapy. Surgery is not considered a successful option in PC therapy due to diagnosis of PC at advanced stages. Therefore, chemotherapy has been primarily used for the treatment of PC patients. However, drug resistance emerges in PC and different molecular pathways including long non-coding RNAs [181], SRPX2 [182] and USP7 [183], among others can participate in the resistance of PC cells to chemotherapy. Furthermore, drug resistanttumor cells, especially PC cells, demonstrate high growth and invasion rates and based on previous discussions, siRNAs can be potentially beneficial in impairing tumor proliferation as well as metastasis and causing subsequent increase in chemosensitivity of PC cells.

Ribonucleotide reductase (RR) is a rate-limiting enzyme vital for DNA synthesis and replication [184]. Celastrol can suppress progression of PC cells via down-regulating RRM2 expression, showing tumor-promoting function of this pathway [185]. Exposing PC cells to RRM2-siRNA leads to an increase in apoptosis and cell growth inhibition. Noteworthy, co-administration of RRM2-siRNA and doxorubicin (DOX) can lead to synergistic effect and a four-fold increase in anti-tumor activity [186]. Gemcitabine (GEM) is another chemotherapeutic agent that its potential in PC treatment has been reduced due to emergence of drug resistance [187]. The hTERT-siRNA can increase the number of PC cells undergoing apoptosis. The hTERT down-regulation induces cell cycle arrest at G0/G1 phase and enhances number of PC cells in S and G2/M phases [188]. Following hTERT down-regulation by siRNA, expressions of Bcl-2 and COX-2, as tumor-promoting factors undergo inhibition that is of importance for inducing apoptosis in PC cells [189], and enhancing their sensitivity to chemotherapy.

Now, it is obvious that when cancer cells demonstrate malignant behavior in terms of proliferation and migration, they can obtain chemoresistance [190-196]. Therefore, in order to provide effective cancer chemotherapy, it is vital to suppress the various pathways that lead to cancer migration and growth [193,197]. It appears that an overexpression of heterogeneous nuclear ribonucleoprotein A2/B1 (hnRNP A2/B1) is in favor of PC growth [102]. As RNA-binding proteins, hnRNP A2/B1 participates in mRNA processing and telomere biogenesis [198]. Clinical study evaluating 42 patients with PC has shown role of hnRNP A2/B1 in PC and its association with E-cadherin, an important epithelial marker [199]. The exposure of PC cells to hnRNP A2/B1 can lead to apoptosis induction. A combination of hnRNP A2/B1 and chemotherapeutic agents such as 5-fluorouracil (5-FU), oxaliplatin and GEM can stimulate synergistic effect against PC cells. In fact, by suppressing PC growth, hnRNA A2/B1-siRNA enhances sensitivity of PC cells to chemotherapy. This com- 
bination leads to Bcl-2 down-regulation and Bax up-regulation, providing apoptotic cell death. Moreover, expression of P-glycoprotein, as a drug transporter that induces chemoresistance [200], decreases following this combination that is of importance in enhancing chemosensitivity [201].

Increasing evidence demonstrates that RR and thymidylate synthase (TS) can induce chemoresistance in cancer cells [202,203]. It has been reported that RRM2-siRNA, as a subunit of RR can promote GEM sensitivity, in vitro and in vivo [203,204]. A combination of GEM and RR- and TS-siRNA can stimulate apoptosis in PC cells and reduces their proliferation. This combination inhibits NF- $\mathrm{kB}$ activation following GEM administration and enhances TNF-related apoptosis-inducing ligand (TRAIL)-mediated cell death in PC cells [205]. In the previous section, it was mentioned that HIF-1 $\alpha$ is a desirable factor for progression of PC cells. Moreover, HIF- $1 \alpha$ down-regulation by siRNA leads to an increase in chemosensitivity of PC cells [206]. A set of tumor-promoting factors such as HIF- $1 \alpha$, ARNT, PFKFB4, and RBKS can be down-regulated by siRNA in inducing apoptosis and enhancing their sensitivity to chemotherapeutic agents including DOX and GEM (Figures 2 and 3) [207]. The interesting point of this section is that prior studies have considered role of both molecular pathways and drug transporters in triggering drug resistance in PC and these molecular pathways and mechanisms can be markedly suppressed using siRNAs as an effective tool. Table 2 summarizes application of siRNAs in down-regulating tumor-promoting factors in PC therapy.

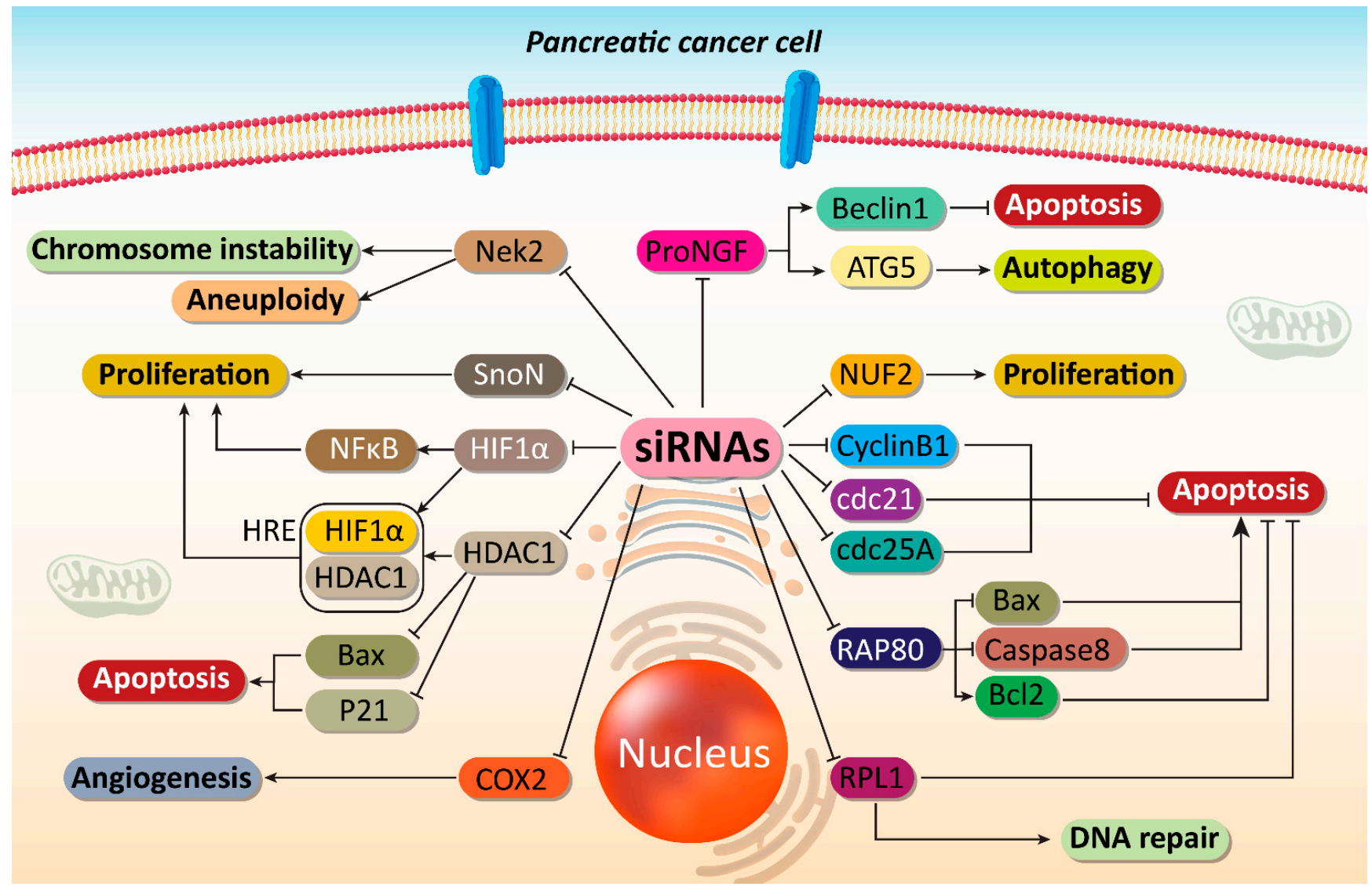

Figure 2. Impairing proliferation and angiogenesis of PC cells. Major molecular pathways can be targeted by siRNAs to induce apoptosis and DNA damage in PC cells. Moreover, angiogenesis responsible for PC progression can be suppressed by siRNAs in PC therapy. ProNGF, precursor of nerve growth factor; ATG, autophagy-related gene; COX2, cyclooxygenase-2; HDAC1, histone deacetylase 1 ; HIF- $1 \alpha$, hypoxia inducible factor- $1 \alpha$; NF- $\mathrm{B}$, nuclear factor-kappaB; siRNA, small interfering RNA; PC, prostate cancer.

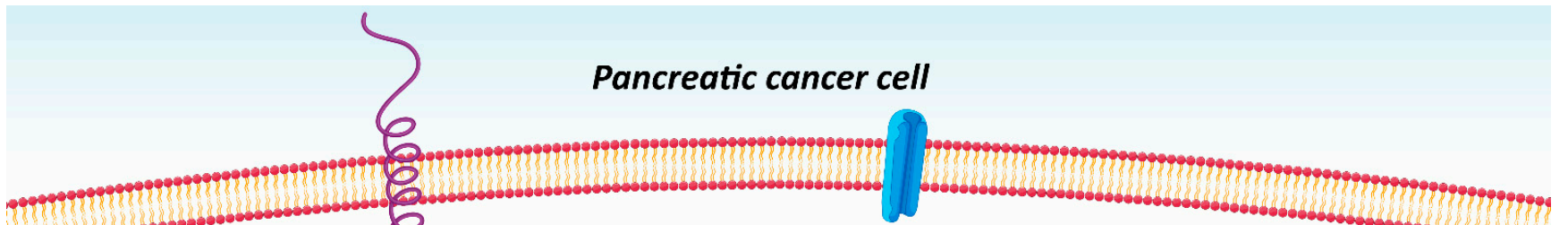


Table 2. Interference with PC progression via application of siRNAs.

\begin{tabular}{|c|c|c|c|c|}
\hline In Vitro/In Vivo & Cell Line/Animal Model & SiRNA & Outcomes & Refs \\
\hline $\begin{array}{l}\text { In vitro } \\
\text { In vivo }\end{array}$ & $\begin{array}{l}\text { PANC-1 and Sw1990 cell } \\
\text { lines Xenograft nude mice }\end{array}$ & NUF2 & $\begin{array}{l}\text { Cell cycle arrest at G0/G1 phase } \\
\text { Down-regulation of Cdc2, Cyclin B1 and Cdc25A }\end{array}$ & [101] \\
\hline In vitro & $\begin{array}{l}\text { AsPC- } 1 \text {, SUIT- } 2 \text {, and } \\
\text { Panc- } 1 \text { cells }\end{array}$ & Survivin & $\begin{array}{c}\text { Suppressing carcinogenesis } \\
\text { Reducing promoter activity and mRNA expression } \\
\text { of survivin } \\
\text { Inducing caspase-3 expression and DNA } \\
\text { fragmentation } \\
\text { Enhancing radiosensitivity }\end{array}$ & [208] \\
\hline In vitro & SW1990 and Capan-2 cells & RAP80 & $\begin{array}{c}\text { Down-regulating Bcl-2 and up-regulating Bax } \\
\text { Inducing apoptotic cell death } \\
\text { Increasing TRAIL-mediated apoptosis } \\
\text { Promoting GEM sensitivity }\end{array}$ & [109] \\
\hline In vitro & Panc- 1 and BxPC 3 cells & Survivin & $\begin{array}{c}\text { Decreasing mRNA and protein levels of survivin } \\
\text { Suppressing cell proliferation } \\
\text { Triggering cell cycle arrest at G0/G1 phase } \\
\text { Reducing gene expression by } 17 \%\end{array}$ & [209] \\
\hline In vitro & BxPC3 cells & S100A4 & $\begin{array}{l}\text { Down-regulating MMP-2 } \\
\text { Enhancing levels of E-cadherin and TSP-1 } \\
\text { Suppressing cancer invasion and metastasis }\end{array}$ & [210] \\
\hline In vitro & $\begin{array}{l}\text { PANC-1, MIA-PaCa-2 and } \\
\text { ASPC-1 cells }\end{array}$ & TrKA & $\begin{array}{l}\text { TrKA down-regulation is associated with GEM } \\
\text { sensitivity } \\
\text { Inducing apoptotic cell death } \\
\text { Inhibiting PI3K/Akt signaling pathway }\end{array}$ & [211] \\
\hline
\end{tabular}

Table 2. Cont.

\begin{tabular}{|c|c|c|c|c|}
\hline In Vitro/In Vivo & Cell Line/Animal Model & SiRNA & Outcomes & Refs \\
\hline In vitro & BxPC 3 cells & hTERT & $\begin{array}{c}\text { Apoptosis stimulation } \\
\text { Cell cycle arrest at G0/G1 phase } \\
\text { Enhancing GEM sensitivity }\end{array}$ & [188] \\
\hline In vitro & MiaPaCa2 cells & HIF- $1 \alpha$ & $\begin{array}{l}\text { Interfering with cancer proliferation } \\
\text { Apoptosis induction } \\
\text { Disrupting cancer growth under hypoxic conditions }\end{array}$ & [113] \\
\hline In vitro & PaTu8988 cells & DNMT1 & $\begin{array}{l}\text { Apoptosis induction and inhibiting tumor growth } \\
\text { by cell cycle arrest (S phase) } \\
\text { DNMT1 down-regulation and subsequent } \\
\text { activation of hMLH1 as a tumor-suppressor factor }\end{array}$ & [115] \\
\hline In vitro & PANC-1 cells & RRM2 & $\begin{array}{l}\text { Exerting synergistic effect with doxorubicin and } \\
\text { enhancing cytotoxicity against cancer cells by } 4 \text {-fold }\end{array}$ & [186] \\
\hline In vitro & MiaPaCa-2 cells & K-Ras & $\begin{array}{c}\text { Down-regulating K-Ras expression } \\
\text { Triggering apoptosis }\end{array}$ & [212] \\
\hline In vitro & SW1990 cells & SnoN & $\begin{array}{l}\text { Down-regulating SnoN expression and reducing } \\
\text { cancer cell proliferation } \\
\text { Apoptosis induction }\end{array}$ & [121] \\
\hline In vitro & SW1990 and BxPC-3 cells & hnRNP A2/B1 & $\begin{array}{c}\text { Stimulating apoptosis via Bcl-2 down-regulation } \\
\text { and Bax up-regulation } \\
\text { Mediating TRAIL-induced apoptosis } \\
\text { P-glycoprotein down-regulation } \\
\text { Suppressing cancer metastasis via enhancing } \\
\text { E-cadherin levels }\end{array}$ & [201] \\
\hline $\begin{array}{l}\text { In vitro } \\
\text { In vivo }\end{array}$ & $\begin{array}{l}\text { Capan- } 2 \text { cells } \\
\text { Nude mice }\end{array}$ & COX-2 & $\begin{array}{l}\text { Cell cycle arrestApoptosis induction } \\
\text { Decreasing cancer cell proliferation } \\
\text { Disrupting cancer growth and survival }\end{array}$ & [155] \\
\hline In vitro & PaTu8988 cells & HDAC-1 & $\begin{array}{l}\text { Inducing cell cycle arrest ( } \mathrm{S} \text { phase) and apoptosis } \\
\text { Enhancing Bax and p21 expressions }\end{array}$ & [139] \\
\hline $\begin{array}{l}\text { In vitro } \\
\text { In vivo }\end{array}$ & PANC-1 and BxPC-3 cells & RPL21 & $\begin{array}{l}\text { Cell cycle arrest at G1 phase } \\
\text { Apoptosis induction via mitochondrial pathway } \\
\text { Caspase- } 8 \text { activation }\end{array}$ & [127] \\
\hline
\end{tabular}




\section{Chemical Modification of siRNAs}

In addition to nanoscale delivery systems, stability and potential of siRNA in gene silencing can be improved by chemical modification. The RNAi activity of siRNA mainly depends on the length and structure of siRNA. The $5^{\prime}-\mathrm{OH}$ of siRNA possesses a phosphate group that seems to be essential for loading into RISC complex and mediating its optimal functions $[213,214]$. Moreover, double-stranded siRNA should have A-type duplex to provide RNAi activity [213-215]. The guide strand RNA-Ago2 complex has two regions including seed region and central region. The seed region has 2-8 nucleotides and is responsible for forming duplex with mRNA, while central region has 10-11 nucleotides and cleaving site of mRNA is complementary to the central region. These regions are vital for identification of target mRNA and helping RISC complex enzymes in RNA separation [216]. However, as was mentioned previously, application of siRNA as a drug has problems and chemical modification of siRNA should be performed in improving its binding affinity with mRNA, preventing enzyme degradation, providing site-specific delivery and decreasing off-targeting [217]. The sugar ring, phosphate backbones and nucleobase sites are ideal candidates for chemical modification of siRNA and improving its potential in gene expression regulation [218]. The $2^{\prime}$ sugar modifications of siRNA including $2^{\prime}$-O-methyl, $2^{\prime}$-fluoro (2'-F) and 2'-O-(2-methoxyethyl) (2'-MOE) are beneficial in improving biocompatibility of siRNA, decreasing its immunogenicity and providing resistance to enzyme degradation $[219,220]$. Furthermore, siRNA uptake by cells can be improved via conjugation of siRNAs to lipophilic agents such as $\mathrm{N}$-acetylglactosamine and cholesterol [221]. A new study has synthesized 2'-caged siRNA for targeting GFP gene in HEK293T cells. These $2^{\prime}$-caged-tethered-siRNAs were light-responsive and their activity was low in dark conditions, whereas exposing these siRNAs to light significantly elevated their RNAi activity and their potential in gene regulation [222].

It is worth mentioning that chemical modifications may negatively affect potential of siRNA in gene silencing. A recent experiment showed that KL4 peptide is optimal for increasing cellular uptake of siRNAs. Then, KL4 peptide was modified, so that hydrophobic leucine was replaced by alanine or valine. The modified peptide has cationic charge that was proper for interacting with negatively charged siRNA. However, this modification changed structure of KL4 peptide from $\alpha$-helix to $\beta$-sheet that reduced potential of this peptide in enhancing siRNA efficacy [223]. Therefore, siRNA modification or changes in its conjugations should be appropriately performed to prevent unsuccessful results. For instance, conjugation of ODAGal4 to siRNA can significantly elevate the stability of siRNA and protect it against degradation by serum enzymes [224]. Another experiment highlighted the impact of chemical modification on siRNA efficacy. This study modified guide strand of siRNA by $3^{\prime}$ terminal modifications (2'-O-methyl versus $2^{\prime}$-fluoro). For siRNAs with guide strand with 20 nucleotides, such modification reduced its activity, while this is not true for guide strands with 19 or 21 nucleotides, modulating length of siRNAs can serve as determining factor and facilitate their chemical modifications. To improve efficacy of siRNAs by altering $3^{\prime}$ terminal $2^{\prime}$-O-methyl modification, another study introduced an extra $2^{\prime}$-fluoro modification in the seed region at guide strand position 5, but not 7 [225]. One of the primary positions that can be modified for improving potential of siRNAs to regulate gene expression is $5^{\prime}$ nucleobase that is responsible for the interaction between siRNA and Ago2. For instance, another study has used an adenine-derived analog, known as 6-mCEPh-pourine to modify $5^{\prime}$ end of siRNA that significantly improved potential of siRNA in reducing gene expression in vitro and in vivo [226]. Another experiment also revealed that $5^{\prime}$ end modification of siRNA by 6-mCEPh-pourine can be advantageous in promoting the generation of mature RICS by enhancing RISC stability and fixing loading orientation of siRNA duplexes [227]. Therefore, targeted chemical modifications of siRNA can be beneficial in improving its efficacy in gene silencing [228]. However, there are no prior studies reported about chemical modifications of siRNA and their possible applications in pancreatic cancer therapy. Therefore, future experiments can focus on how 
chemical modifications of siRNA can improve its efficacy in pancreatic cancer suppression via affecting and modulating genes as well as molecular pathways.

\section{Co-Delivery Systems}

\subsection{Lipid-Based Nanoparticles}

Although previous sections have obviously demonstrated the potential application of siRNA in PC therapy, and its efficiency in suppressing cancer proliferation and invasion, it seems that more progress can be made in effective PC therapy by loading siRNA on nanoparticles to promote its intracellular accumulation and protect against degradation [229-235]. In this section, different kinds of nanostructures applied for siRNA delivery in PC are discussed.

Liposomes are one of the well-known carriers for drug and gene delivery due to their great properties including long blood circulation, high stability, high drug loading and controlled release [236-239]. To enhance targeted delivery of liposomes, they can be functionalized by ligands that target overexpressed receptors on surface of cancer cells that EGFR is among them with up-regulation in PC cells [240,241]. Anti-EGFR antibodies are extensively applied in nanocarrier modification due to their low size, biocompatibility, low immunogenicity and easy conjugation on surface of nanoparticles. GE11 is a peptide that has been applied for targeting EGFR on the surface of cancer cells [242,243]. Recently, GE11 peptide antibody-targeted liposomes have been applied for co-delivery of GEM and HIF- $1 \alpha-$ siRNA. HIF- $1 \alpha$ up-regulation occurs in hypoxic conditions. The overexpression of HIF- $1 \alpha$ is in favor of PC progression [244] and can mediate drug resistance [245]. Co-delivery of HIF$1 \alpha$ siRNA and GEM leads to a four-fold decrease in tumor growth. Apoptosis induction, DNA fragmentation and chromatin condensation can occur following administration of liposomes. It seems that using siRNA can effectively promote anti-tumor activity by twofold [246]. This study demonstrated that how liposomes can enhance anti-tumor activity, and how siRNA can promote apoptosis induction in cancer cells by down-regulating tumor-promoting signaling pathways. Interestingly, liposomes can provide a platform for co-delivery of siRNA with other anti-tumor agents. Recently, GEM and myeloid cell leukemia 1 (Mcl-1)-siRNA have been loaded on liposomes for PC therapy (Figure 3). Liposomes demonstrated high cellular uptake, resulting in Mcl-1 down-regulation as a tumor-promoting factor for PC cells. Thus, sensitivity of PC cells toward GEM increased and an increase occurred in the number of PC cells undergoing apoptosis [247].

Overall, two major categories of nanocarriers have been applied for siRNA delivery including liposomes and polymeric nanoparticles [248-251]. The liposomes used for siRNA delivery are cationic in nature. Positively charged lipids can encapsulate a high amount of siRNA via electrostatic interaction. However, toxicity, immunostimulatory and activating inflammation are drawbacks of cationic liposomes $[249,252]$. Similarly, polymers applied for siRNA delivery possess positive charge and severe toxicity is still a major challenge for these kinds of nanostructures. To promote efficiency of polymeric nanoparticles in siRNA delivery, they are designed with high charge densities that can be modulated based on their toxicities.

It has also been reported that lipid-polymer hybrid nanoparticles are potential carriers in siRNA delivery. The structure of lipid-polymer hybrid nanoparticles includes a polymeric core surrounded by a single layer or bilayer lipid shell, combining benefits of both liposomes and polymeric nanoparticles. The cationic core is responsible for encapsulation of siRNA, and can provide protection, biocompatibility as well as in vivo stability $[253,254]$. Lipid-polymer hybrid nanoparticles have been designed for co-delivery of GEM and HIF$1 \alpha$-siRNA in PC therapy. The negatively charged HIF- $1 \alpha$-siRNA is encapsulated on the surface, while GEM is embedded into hydrophilic core. Then, they are encapsulated by PEGylated lipid bilayer that can prevent siRNA degradation and aggregation as well as GEM leakage. These nanocarriers can enhance lifetime in bloodstream and increase tyhe drug release via penetrating into tumor vasculature. In vivo and in vitro experiments 
demonstrated down-regulation of HIF- $1 \alpha$ and effective delivery of GEM in suppressing PC progression [255].

The different kinds of nanocarriers applied for siRNA delivery not only prevent siRNA degradation, but also inhibit renal clearance following systemic administration [42] Moreover, nanostructures possess a size lower than $100 \mathrm{~nm}$ that is of importance in accumulating in tumor site via defective neovasculature surrounding tumor, known as enhanced permeability and retention (EPR) effect [256,257]. PEG-based block catiomers can spontaneously assemble siRNA into micelles, providing a biocompatible PEG shell for siRNA delivery [258]. Chemical cross-linking and hydrophobic interactions derived from hydrophobic moieties can enhance stability of micelles [42,259]. Furthermore, targeted delivery of micelles can be improved via using ligands specifically targeting overexpressed receptors on surface of cancer cells [260]. For this reason, Min and colleagues have designed antibody fragment (Fab')-installed polyion complex (PIC) micelles for enhancing siRNA delivery in PC cells. The prepared micelles demonstrated diameter as low as $40 \mathrm{~nm}$. PIC micelles demonstrated high affinity to PC cells overexpressing tissue factor (TF). This led to high internalization and penetration into PC cells. Subsequently, highest decrease occurred in expression of polo-like kinase $1 \mathrm{mRNA}$, after using PIC micelles containing siRNA [261].

\subsection{Polymeric Nanoparticles}

Polymeric nanoparticles are considered to be ideal candidates in siRNA delivery because of their biodegradability $[238,239,262]$. Biodegradable charged polyester-based vectors (BCPVs) can be degraded under the physiological conditions and have been successfully applied for siRNA delivery [263]. On the other hand, K-Ras family proteins are guanine nucleotide binding proteins capable of regulating activity of pancreatic cells and are involved in modulating proliferation, apoptosis and migration [264-266]. Following $\mathrm{K}$-Ras mutation, several downstream signaling networks were activated that imparted cancer malignancy [267].

The role of K-Ras in PC growth was confirmed when the cancer cells were exposed to K-Ras-siRNA and the number of PC cells undergoing apoptosis demonstrated an increase [212]. K-Ras-siRNA-loaded BCPVs have been designed for PC therapy. After $72 \mathrm{~h}$, BCVPs demonstrate good accumulation in cancer cells and they can diminish mRNA and protein expression up to $50 \%$. These siRNA-loaded nanostructures effectively penetrate into PC cells to induce apoptosis, and growth inhibition [268]. Efficacy of polymeric nanocarriers in siRNA delivery can be boosted via their surface modifications. The internalizing RGD peptide (iRGD) functions by binding to integrins overexpressed on tumor vasculature [269]. Using iRGD also significantly elevated tumor-penetrating capability $[270,271]$. Surface modification by iRGD is associated with an increase in siRNA delivery to cancer cells, and subsequent enhance in gene silencing and reducing tumor growth [272]. In fact, RGD can bind to $\alpha \mathrm{v} \beta 3 / 5$ integrins on surface of cancer cells, leading to an increased transfection efficiency [273]. One of the achievements of using polymeric nanoparticles for siRNA in PC therapy is EPR effect. However, in PC cells, due to hypovascularity and dense desmoplastic stroma, intravenous administration (IV) can decrease efficiency of nanostructures in siRNA delivery and cancer elimination, Hence, intraperitoneal administration has been suggested [274].

It has been established that hypoxia is in favor of cancer growth by activation of HIF- $1 \alpha$ signaling and its downstream targets [275]. Interestingly, it was reported that endothelial PAS domain protein 1 (EPAS1) is also activated under hypoxic conditions. EPAS1 overexpression is an obvious finding in cancer and can enhance cancer metastasis via EMT induction $[276,277]$. The polyethylenimine-poly(lactide-coglycolide) (PLGA)/poloxamer nanoparticles loaded with EPAS1 siRNA have been applied for PC therapy. In vitro and in vivo experiments demonstrated that EPAS1 down-regulation in PC cells due to targeted delivery, resulted in a reduction in cancer proliferation and the number of microvessels [278]. G protein-coupled receptor (GPCR) 87 located on chromosome 3q24 is involved in encoding protein that has an extracellular $\mathrm{N}$ terminus, seven helices, three intracellular 
loops, three extracellular loops and an intracellular C terminus [279,280]. GPCRs are located on the surface of cells and their overexpression can lead to the cancer survival [281,282].

The up-regulation of GRP78 occurs in PC that can mediate chemoresistance via inducing activity of ATP-binding cassette (ABC) drug transporters [283]. GRP78 can induce Yes-associated protein (YAP) in providing radio-resistance [284]. Recently, PLGA nanoparticles containing GRP78-siRNA have been prepared for PC therapy. To prevent polydispersity and large size of nanoparticles, mild agitation was used for encapsulating siRNA in PLGA nanoparticles. The synthesized PLGA nanoparticles demonstrate low size of $92 \mathrm{~nm}$. The expression of GRP8 decreased up to $83.9 \%$ that showed high cytotoxicity of these nanocarriers against PC cells [285]. The advantages of using nanoparticles is that the capability of siRNAs in gene silencing increases due to enhanced intracellular accumulation. That is why experiments have focused on using nanostructures for siRNA delivery in cancer therapy [286]. Local drug EluteR (LODER) is a biodegradable polymeric matrix applied for siRNA in PC therapy. It can protect siRNA against degradation and has high biocompatibility, appropriate for siRNA delivery [287]. Moreover, polymeric nanoparticles can provide endosomal escape of siRNA that is of importance in enhancing its efficacy in gene silencing and suppressing PC progression [288]. An experiment has revealed that using polymeric nanoparticles can provide transfection efficiency as much as $90 \%$ [289]. It appears that these two factors are important in designing smart siRNA polymeric carriers including low pKa amines and hydrophobic moieties inside chain [290].

\subsection{Carbon-Based Nanoparticles}

Two-dimensional (2D) nanomaterials are extensively applied in the field of medicine due to their great electronic, optical and chemical characteristics [291,292]. Graphene is a well-known 2D nanomaterial capable of gene delivery in cancer [293]. To improve biocompatibility of graphene nanomaterials, their surface can be functionalized by compatible polymers such as polyethylene glycol (PEG) [294]. The PEGylated graphene oxide nanosheets have been designed for delivery of siRNA in PC therapy. These biocompatible nanomaterials can successfully down-regulate HDAC1 and K-Ras in suppressing proliferation and triggering apoptosis and cell cycle arrest. In vivo experiment demonstrated an inhibition of cancer growth as much as $80 \%$ following delivery of siRNA by graphene nanosheets [295].

\subsection{Dendrimers}

As it was mentioned, naked siRNAs can poorly penetrate into the cells due to their high molecular weights and high density of negative charge [248]. Moreover, nucleases can easily degrade siRNA in plasma, thus remarkably reducing its efficiency in gene silencing [278]. Dendrimers are a class of materials applied for gene and drug delivery due to their highly branched and precise molecular structures [296,297]. Dendrimers can provide endosomal release and intracellular uptake of siRNA in cancer cells [298]. Furthermore, dendrimers can be applied for co-delivery of chemotherapeutic agents and siRNA in effective cancer chemotherapy by down-regulating the tumor-promoting molecular pathways and enhancing cytotoxicity of anti-tumor agents [299]. On the other hand, targeted delivery of dendrimers can be improved using plectin- 1 targeted peptide (PTP), as a biomarker of PC. PTP peptide modified dendrimers have been designed for co-delivery of paclitaxel (PTX) and TR3-siRNA in PC therapy. These smart nanostructures are redox-responsive and can induce endosomal escape and provide siRNA against degradation. Enhanced intracellular accumulation of TR3-siRNA and PTX resulted in an increase in their cytotoxicity against PC (in vitro and in vivo) [300].

\subsection{Metal-Based Nanoparticles}

Superparamagnetic iron oxide nanoparticles (SPIONs) are a novel kind of nanocarriers being used in field of cancer therapy. They have been used for gene and drug delivery in cancer eradication. SPIONs can enhance intracellular accumulation of DOX in breast 
cancer cells to promote apoptosis induction [301]. They can also be considered to be acting as radiosensitizer in cancer therapy [302]. SPIONs are biocompatible with low size. They can carry siRNA in down-regulating oncogene signaling pathways (HIF- $1 \alpha / \mathrm{CD} 73)$ in disrupting cancer progression [303]. On the other hand, polo-like kinase 1 (PLK1) is a tumor-promoting factor and its overexpression is correlated with an increase in PC growth and induction of chemoresistance [304,305]. Tumor-suppressor factors such as miRNA23a diminish PLK1 expression in inhibiting PC proliferation and invasion [306]. In an experiment, SPION have been designed for delivery of PLK1-siRNA in PC therapy. To promote specificity of SPIONs in targeting PC cells, their surface has been modified with a tumor-selective peptide (EPPT1). Remarkable accumulation of SPIONs carrying siRNA occurs in cancer cells, thus causing PLK1 down-regulation. This can induce apoptosis and suppress proliferation and growth of PC cells. The interesting point is that in vivo and in vitro experiments have confirmed the potential role of siRNA-loaded SPIONs in PC therapy [307]. Clinical studies will shed more light on efficacy of SPIONs in gene delivery for cancer therapy.

Gold nanostructures are promising candidates for nucleic acid delivery due to their adjustable size, multiple functional capabilities and surface properties [308-313]. Gold nanoparticles can be applied for nucleic acid delivery with minimum toxicity and offtargeting [314-316]. On the other hand, nerve growth factor (NGF) is considered to be an inducer of cancer proliferation and its inhibition can be correlated with apoptosis induction [317]. NGF can promote proliferation of PC cells via inducing phosphoinositide 3-kinase (PI3K) / protein kinase B (Akt) axis [318]. Gold nanoclusters have been designed for delivery of NGF-siRNA in PC therapy. Moreover, using gold nanoparticles for delivery both stability and intracellular accumulation of siRNAs can be increased effectively. NGFsiRNA-loaded gold nanoparticles can markedly suppress cancer growth by causing NGF down-regulation without exhibiting any major side effects [319].

Mesoporous silica nanoparticles (MSNPs) are considered to be efficient drug delivery platforms due to their characteristics including that of large surface area and ordered porous channels [320,321]. In addition, MSNPs have been found to be safe, biocompatible and biodegradable [322,323]. Recently, much attention has been directed towards using MSNPs for siRNA delivery in cancer therapy. MSPNs can be administered through intravenous route in mouse models of breast cancer, while their potential in siRNA delivery is maintained [324]. MSNPs can provide a platform for co-delivery of siRNA with anti-tumor agents [325]. Their efficacy in siRNA delivery can be improved via surface modification by chloroquine [326]. An experiment has designed MSNP for siRNA delivery in PC therapy. To enhance intracellular uptake of MSNPs, their surface has been coated with polyethyleneimine (PEI). In addition to increasing cell internalization, PEI can provide a cationic charge that is in favor of encapsulating negatively charged siRNA. The drawback of PEI is negatively affecting biocompatibility profile of MSNPs, but these effects have been found to be only partial. Moreover, to reduce the cytotoxicity against normal cells, $10 \mathrm{kD}$ PEI can be used instead of $25 \mathrm{kD}$ PEI. They can effectively deliver siRNA and PTX to PC cells, as was shown by fluorescence technique (70\% transfection efficiency) [327].

\subsection{Viral Vectors}

Although previous sections were allocated to application of nanomaterials as nonviral vectors for siRNA delivery in cancer therapy, it seems that viral vectors are also capable of effective delivery of siRNA to PC cells that has been discussed in this section. Increasing evidence demonstrates potential of viral vectors for siRNA delivery in cancer therapy [328-330]. Retroviral vectors are applied for siRNA generation induced by either U6- or H1-RNA promoter to provide stable knock-down of targeted gene [328,329]. However, retroviral vectors have a narrower spectrum of cell types compared to adenovirus due to integrating into genome [331,332]. Recombinant adenoviruses are considered to be ideal candidates for cancer gene therapy. For generating recombinant adenoviruses, a simple approach known as AdEssay has been used [333]. Recombinant adenoviruses can be 
applied for inducing persistent loss of functional phenotypes. In PC therapy, K-Ras-siRNA can be delivered by adenoviruses in silencing its expression and suppressing PC progression [334]. Another study has used adenovirus vector for delivery of Mcl-1 in PC therapy. Mcl-1 can regulate mitochondrial activation and undergoes up-regulation in several cancers [335-337]. Following introduction of Mcl-1-siRNA-loding adenovirus, a significant decrease occurs in PC cells that can induce apoptosis via caspase-3 up-regulation. It seems that Mcl-1-down-regulation by adenovirus is in favor of promoting radiosensitivity of PC cells [338]. These studies demonstrated efficiency of adenoviruses in down-regulating tumor-promoting factors such as Gli1 in inhibiting PC proliferation and viability [339]. Figure 4 and Table 3 describe the role of different co-delivery systems for application of siRNAs in PC therapy. Figure 5 illustrates the potential of siRNA-loaded nanoparticles in affecting different molecular pathways in PC therapy. 


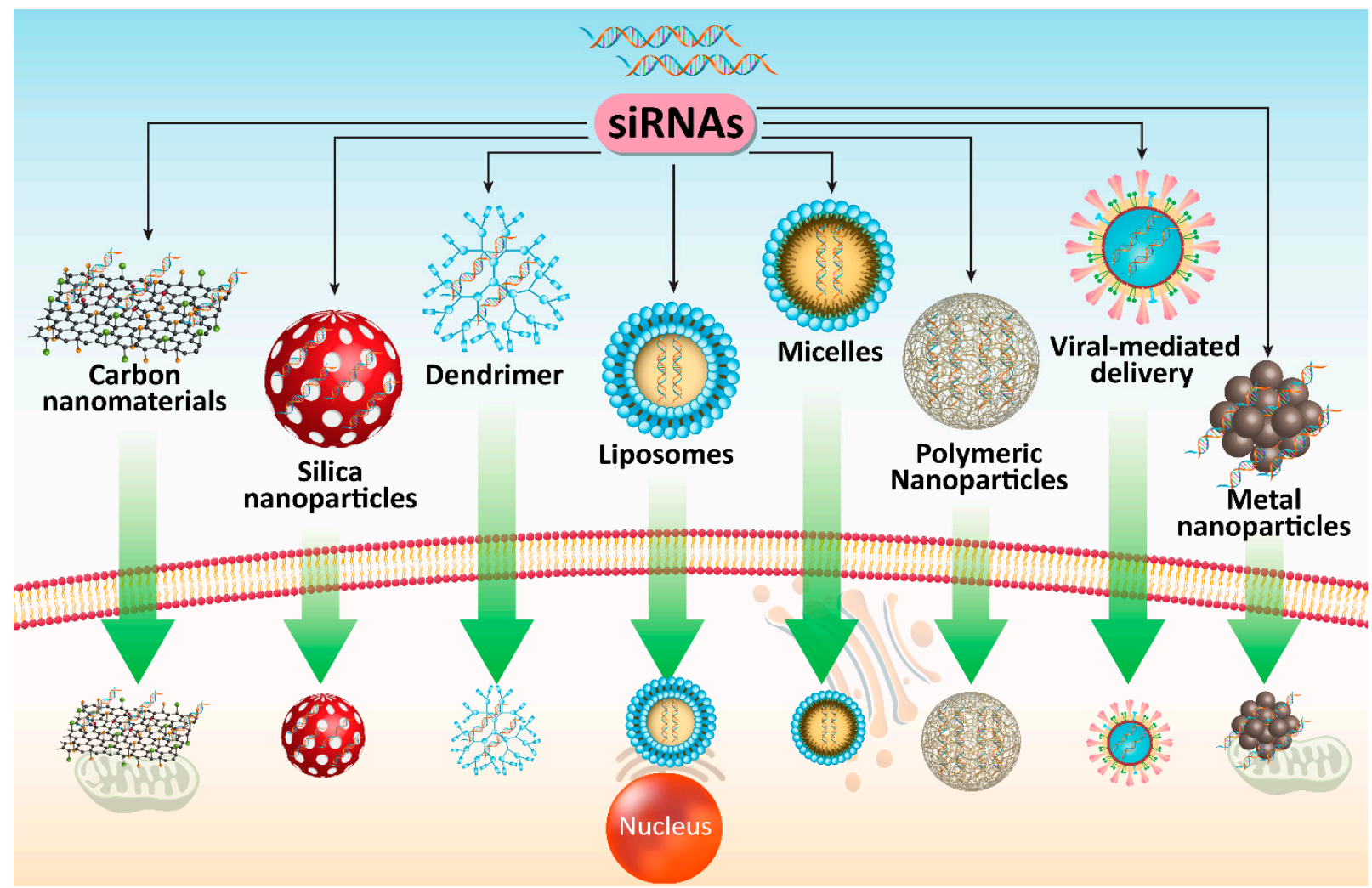

Figure 4. Different co-delivery systems for siRNA in PC therapy. Enhancing intracellular accumulation, protecting against degradation and increasing efficacy for gene silencing can be obtained using viral and non-viral vectors. SiRNA, small interfering RNA; PC, prostate cancer.

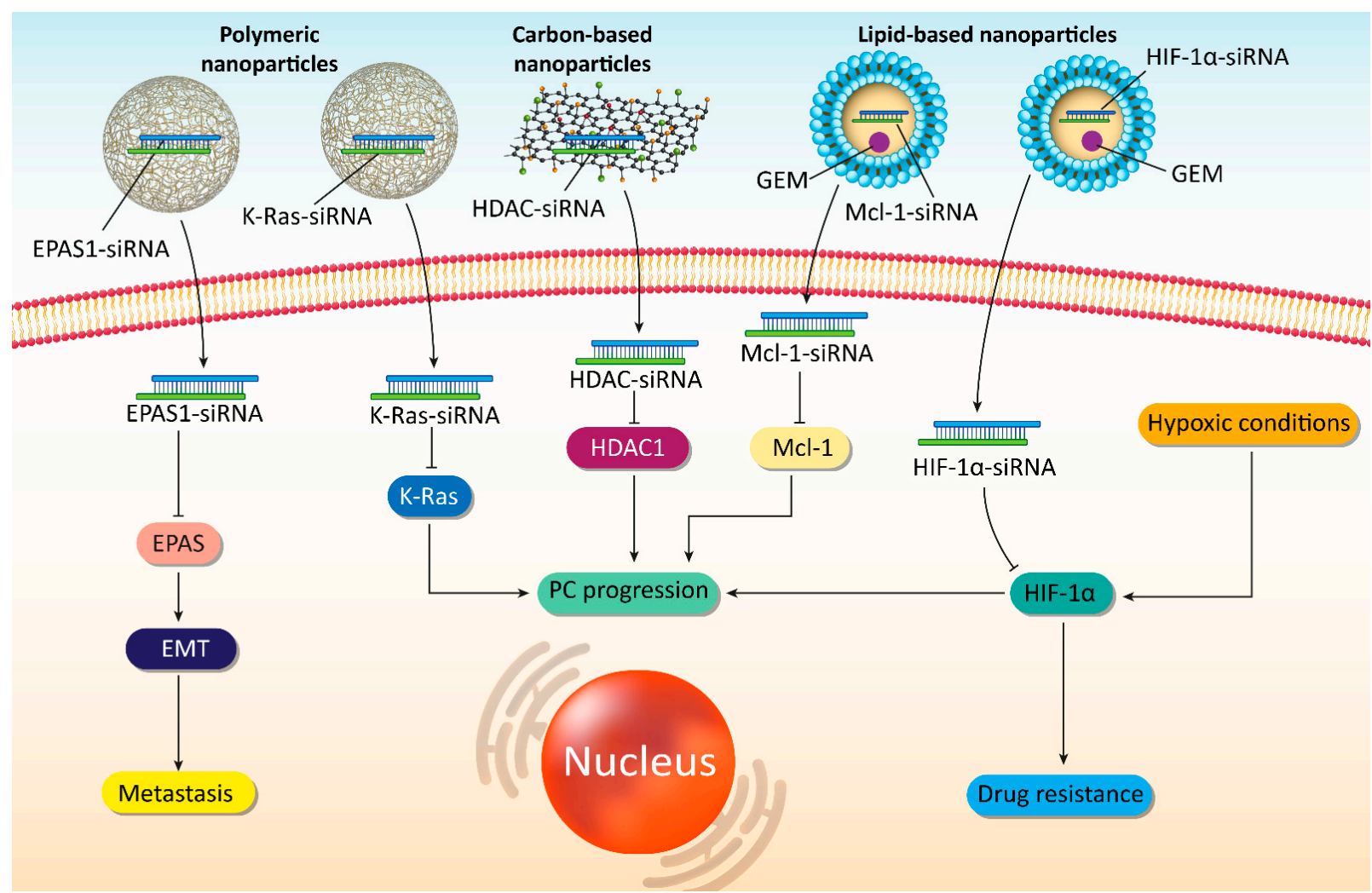

Figure 5. The potential of siRNA-loaded nanoparticles in affecting molecular pathways in PC therapy. 
Table 3. Co-delivery systems for siRNA in PC therapy.

\begin{tabular}{|c|c|c|c|c|c|c|c|}
\hline Vehicle & SiRNA & In Vitro/In Vivo & Cell Line & $\begin{array}{c}\text { Surface } \\
\text { Modification }\end{array}$ & $\begin{array}{c}\text { Particle Size }(\mathrm{nm}) \\
\text { Zeta Potential (mV) } \\
\text { Encapsulation } \\
\text { Efficiency }(\%)\end{array}$ & Remarks & Refs \\
\hline $\begin{array}{c}\text { Polymeric } \\
\text { nanoparticles }\end{array}$ & K-Ras & $\begin{array}{l}\text { In vitro } \\
\text { In vivo }\end{array}$ & $\begin{array}{l}\text { KPC-derived cell } \\
\text { lines and MIA } \\
\text { PaCa- } 2 \text { cells }\end{array}$ & RGD & Not reported & $\begin{array}{c}\text { Gene down-regulation efficiency more } \\
\text { than } 95 \% \\
\text { High cellular uptake } \\
\text { Great internalization } \\
\text { Suppressing PC progression }\end{array}$ & [272] \\
\hline $\begin{array}{c}\text { Lipid-polymer } \\
\text { hybrid nanoparticles }\end{array}$ & HIF- $1 \alpha$ & $\begin{array}{l}\text { In vitro } \\
\text { In vivo }\end{array}$ & PANC-1 cells & $\mathrm{N} / \mathrm{A}$ & $\begin{array}{c}120-140 \mathrm{~nm} \\
-34 \mathrm{mV}\end{array}$ & $\begin{array}{l}\text { Co-delivery of GEM and siRNA in } \\
\text { exerting synergistic effect } \\
\text { Prolonged lifetime in bloodstream and } \\
\text { improved drug release via the enhanced } \\
\text { tumor vasculature effect in tumor } \\
\text { tissues } \\
\text { Suppressing tumor growth and } \\
\text { metastasis } \\
\text { Down-regulating HIF-1 } \alpha \\
\text { Enhancing GEM sensitivity }\end{array}$ & [255] \\
\hline $\begin{array}{c}\text { Polymeric } \\
\text { nanoparticles }\end{array}$ & KRAS & In vivo & KPC8060 cells & $\mathrm{N} / \mathrm{A}$ & Not reported & $\begin{array}{c}\text { Intraperitoneal injection enhances } \\
\text { intracellular accumulation of } \\
\text { nanoparticles to intravenous } \\
\text { administration (15-fold higher) } \\
\text { Enhancing infiltration of T cytotoxic } \\
\text { cells } \\
\text { Inducing delay in tumor growth } \\
\text { Suppressing metastasis } \\
\text { Increasing survival }\end{array}$ & [274] \\
\hline
\end{tabular}


Table 3. Cont.

\begin{tabular}{|c|c|c|c|c|c|c|c|}
\hline Vehicle & SiRNA & In Vitro/In Vivo & Cell Line & $\begin{array}{c}\text { Surface } \\
\text { Modification }\end{array}$ & $\begin{array}{l}\text { Particle Size }(\mathrm{nm}) \\
\text { Zeta Potential }(\mathrm{mV}) \\
\text { Encapsulation } \\
\text { Efficiency }(\%)\end{array}$ & Remarks & Refs \\
\hline $\begin{array}{c}\text { Polymeric } \\
\text { nanoparticles }\end{array}$ & GPR87 & In vitro & HEK293T cells & $\mathrm{N} / \mathrm{A}$ & $\begin{array}{l}\text { Average size of } \\
100-200 \mathrm{~nm} \\
\text { Up to }-15 \mathrm{mV} \\
\text { Up to } 31.14 \%\end{array}$ & $\begin{array}{l}\text { Reducing gene expression up to } 87 \% \\
\text { High efficiency and cytotoxicity against } \\
\text { cancer growth }\end{array}$ & [285] \\
\hline $\begin{array}{c}\text { Polymeric } \\
\text { nanoparticles }\end{array}$ & K-Ras & In vivo & MiaPaCa-2 cells & $\mathrm{N} / \mathrm{A}$ & $\begin{array}{l}97.99 \mathrm{~nm} \\
39.71 \mathrm{mV}\end{array}$ & $\begin{array}{c}\text { High biocompatibility } \\
\text { Potentiality in siRNA delivery and gene } \\
\text { silencing in suppressing cancer } \\
\text { progression }\end{array}$ & [268] \\
\hline $\begin{array}{c}\text { Polymeric } \\
\text { nanoparticles }\end{array}$ & K-Ras & $\begin{array}{l}\text { In vitro } \\
\text { In vivo }\end{array}$ & $\begin{array}{l}\text { PANC-1 and BxPC3 } \\
\text { cells }\end{array}$ & $\mathrm{N} / \mathrm{A}$ & Not reported & $\begin{array}{l}\text { Apoptosis stimulationCell cycle arrest } \\
\text { at G0/G1 phase } \\
\text { Enhanced efficiency in gene silencing }\end{array}$ & [286] \\
\hline Gold nanocluster & NGF & $\begin{array}{l}\text { In vitro } \\
\text { In vivo }\end{array}$ & $\begin{array}{l}\text { Panc- } 1 \text { cells } \\
\text { Tumor models }\end{array}$ & $\mathrm{N} / \mathrm{A}$ & Not reported & $\begin{array}{l}\text { High cellular uptake and intracellular } \\
\text { accumulation } \\
\text { NGF down-regulation } \\
\text { Inhibiting PC proliferation and viability }\end{array}$ & [319] \\
\hline Liposome & HIF- $1 \alpha$ & $\begin{array}{l}\text { In vitro } \\
\text { In vivo }\end{array}$ & Panc- 1 cells & GE11 & $\begin{array}{l}166.4 \mathrm{~nm} \\
22.5 \mathrm{mV}\end{array}$ & $\begin{array}{l}\text { Enhancing GEM sensitivity of cancer } \\
\text { cells via HIF- } 1 \alpha \text { down-regulation }\end{array}$ & [246] \\
\hline Liposome & Mcl-1 & In vitro & $\begin{array}{l}\text { PANC-1 and BxPC3 } \\
\text { cells }\end{array}$ & $\mathrm{N} / \mathrm{A}$ & $\mathrm{N} / \mathrm{A}$ & $\begin{array}{c}\text { Increased efficiency in down-regulating } \\
\text { Mcl-1 } \\
\text { Suppressing GEM resistance }\end{array}$ & [247] \\
\hline Peptide nanoparticles & KRAS & $\begin{array}{l}\text { In vitro } \\
\text { In vivo }\end{array}$ & $\begin{array}{l}\text { KPC-1 murine PDAC } \\
\text { cells }\end{array}$ & $\mathrm{N} / \mathrm{A}$ & Not reported & $\begin{array}{l}\text { Precision delivery to tumor site } \\
\text { High cellular uptake } \\
\text { Potentiality in gene silencing }\end{array}$ & [229] \\
\hline
\end{tabular}


Table 3. Cont

\begin{tabular}{|c|c|c|c|c|c|c|c|}
\hline Vehicle & SiRNA & In Vitro/In Vivo & Cell Line & $\begin{array}{c}\text { Surface } \\
\text { Modification }\end{array}$ & $\begin{array}{c}\text { Particle Size (nm) } \\
\text { Zeta Potential (mV) } \\
\text { Encapsulation } \\
\text { Efficiency (\%) }\end{array}$ & Remarks & Refs \\
\hline
\end{tabular}




\section{SiRNA and Pancreatic Cancer: Clinical Applications}

With respect to the various challenges associated with PC treatment in clinical courses, introducing novel therapeutics is of great importance. Based on the previous sections, siRNAs have shown high potential in PC treatment by targeting tumor-promoting molecular pathways and sensitizing these malignant cells to death. A search on clinicaltrials.gov demonstrates that clinical studies are currently ongoing about potential applications of siRNAs in PC therapy. The mutation in KrasG12D is responsible for PC progression and spread into various regions of the body. A phase I clinical trial by MD Anderson Cancer Center is going on to evaluate role of exosomes derived from mesenchymal stem cells for delivery of KrasG12D-siRNA in PC treatment. This clinical experiment aims at determining the optimal dose and adverse effects of exosomes containing KrasdG12D-siRNA in PC treatment (NCT03608631). When PC cells undergo metastasis and spread in body, it is impossible to treat PC with surgery or tumor resection. Therefore, use of novel strategies has been recommended and siRNAs can also be among them. Immune evasion is a common phenomenon in PC and there are several factors found in immune cells that can hamper their capacity in PC cell eradication. A clinical experiment performed by Wake Forest University Health Sciences aims to develop siRNA-transfected peripheral blood mononuclear cells APN401 in treatment of PC patients (NCT02166255). The major aim of these clinical trials is to show safety profile and toleration of siRNA in PC patients (NCT01188785). One of the limitations of these clinical trials is the limited number of participants. For instance, there clinical trials have been performed for using siRNA and the numbers of participants are 44 (NCT03819387), 29 (NCT01808638) and 24 (NCT00689065). Noteworthy, a phase II clinical trial has been recruited and is going to evaluate siRNA-G12D LODER in combination with gemcitabine and nab-paclitaxel in treatment of PC patients. This clinical trial has 80 participants that is slightly better as compared to the previous ones (NCT01676259). However, patient population is still limited and additional clinical studies are needed with greater number of PC patients. Furthermore, there are no clinical trials reported that have used siRNA-loaded nanoparticles for treatment of PC patients and these can also be the focus of future studies.

\section{Conclusions and Remarks}

In the current review, different aspects of using siRNAs and their delivery systems in PC therapy were discussed. Activation of tumor-promoting factors has been found to responsible for increase in proliferation and metastasis of PC cells. To suppress PC growth and viability, siRNAs have been developed for down-regulating the various tumorpromoting factors including proNGF, RAP80, NUF2, SnoN, HIF- $1 \alpha$, COX-2 and Nek2. Following down-regulation of aforementioned factors, a significant decrease occurs in PC progression, thus showing potential benefits of application of siRNAs in PC therapy. Noteworthy, a variety of factors are also involved in PC migration and invasion. Thus, siRNAs have been designed for inhibiting tumor-promoting factors including TGF- $\beta, c-S r c$, and HIF- $1 \alpha$ to disrupt PC progression and metastasis. The interesting point is that when an increase in the proliferation and migration of PC occurs, they can also obtain resistance to chemotherapy and radiotherapy, which can also be targeted using specific siRNAs.

Despite achieving promising results following siRNA application, it appears that more advancement can be made in suppressing PC progression using optimal delivery systems to prevent siRNA degradation, inhibit off-targeting and enhance targeted delivery. To date, a wide variety of nanocarriers including carbon nanomaterials, micelles, liposomes, polymeric nanoparticles, metal nanoparticles, dendrimers and silica nanoparticles have been developed for enhancing delivery of siRNAs for PC therapy. Using these nanoarchitectures can significantly enhance efficacy of siRNA in gene silencing and promote their intracellular accumulation. It is worth mentioning that viral vectors have also been developed for siRNA delivery in PC therapy. Overall, the studies conducted so far have revealed that siRNAs along with their associated delivery systems can serve as powerful 
tools in PC therapy. Hence, future studies can focus on developing novel carriers for targeting the various tumor-promoting factors in PC therapy.

Author Contributions: A.P.K. and G.S. participated in study design, supervision and English editing. Figures and tables were prepared by M.D. and A.Z. (Ali Zarrabi), S.M., M.A., F.H., A.Z. (Amirhossein Zabolian), S.M., M.H.G., H.L.A., F.H., A.Z. (Ali Zarrabi), A.Z. (Amirhossein Zabolian), K.H., M.D., H.K., contributed to literature search, writing and preparing of manuscript. All authors have read and agreed to the published version of the manuscript.

Funding: This work was supported by grants from Singapore Ministry of Education [MOE-T2EP301200016], the National Research Foundation Singapore and the Singapore Ministry of Education under its Research Centre's of Excellence initiative to Cancer Science Institute of Singapore, National University of Singapore to A.P.K. This was also supported by Singapore Ministry of Education [R-184-000-301-114] Tier 1 grant to GS.

Conflicts of Interest: The authors declare no conflict of interest.

$\begin{array}{ll}\text { Abbreviations } \\ \text { PC } & \text { Pancreatic cancer } \\ \text { siRNA } & \text { Small interfering RNA } \\ \text { BBB } & \text { Blood-brain barrier } \\ \text { BTB } & \text { Blood-tumor barrier } \\ \text { RNAi } & \text { RNA interference } \\ \text { mRNA } & \text { Messenger RNA } \\ \text { RISC } & \text { RNA-induced silencing } \\ \text { Ago } & \text { Argonaute } \\ \text { HSP27 } & \text { Heat shock protein 27 } \\ \text { PARP } & \text { Poly (ADP-ribose) polymerase } \\ \text { ESM-1 } & \text { Endothelial cell-specific molecule-1 } \\ \text { proNGF } & \text { Precursor of nerve growth factor } \\ \text { ATG5 } & \text { Autophagy-related gene 5 } \\ \text { RAP80 } & \text { Receptor-associated protein } 80 \\ \text { HIF-1 } \alpha & \text { Hypoxia inducible factor-1 } \alpha \\ \text { NF-kB } & \text { Nuclear factor-kappaB } \\ \text { COX-2 } & \text { Cyclooxygenase-2 } \\ \text { EGFR } & \text { Epidermal growth factor receptor } \\ \text { VEGF } & \text { Vascular endothelial growth factor } \\ \text { HDAC } & \text { Histone deacetylase } \\ \text { HRE } & \text { Hypoxia response element } \\ \text { HPA } & \text { Heparinase } \\ \text { FGF2 } & \text { Fibroblast growth factor 2 } \\ \text { SDC1 } & \text { Syndecan-1 } \\ \text { EMT } & \text { Epithelial-to-mesenchymal transition } \\ \text { NELFE } & \text { Negative elongation factor E } \\ \text { NDRG2 } & \text { N-Myc downstream-regulated gene 2 } \\ \text { lncRNA } & \text { long non-coding RNA } \\ \text { miRNA } & \text { microRNA } \\ \text { MMP } & \text { Matrix metalloproteinase } \\ \text { TGF- } \beta & \text { Transforming growth factor-beta } \\ \text { RIG-I } & \text { Retinoic acid-inducible gene I } \\ \text { CADM1 } & \text { Cell adhesion molecule 1 } \\ \text { RR } & \text { Ribonucleotide reductase } \\ \text { DOX } & \text { Doxorubicin } \\ \text { GEM } & \text { Gemcitabine } \\ & \end{array}$




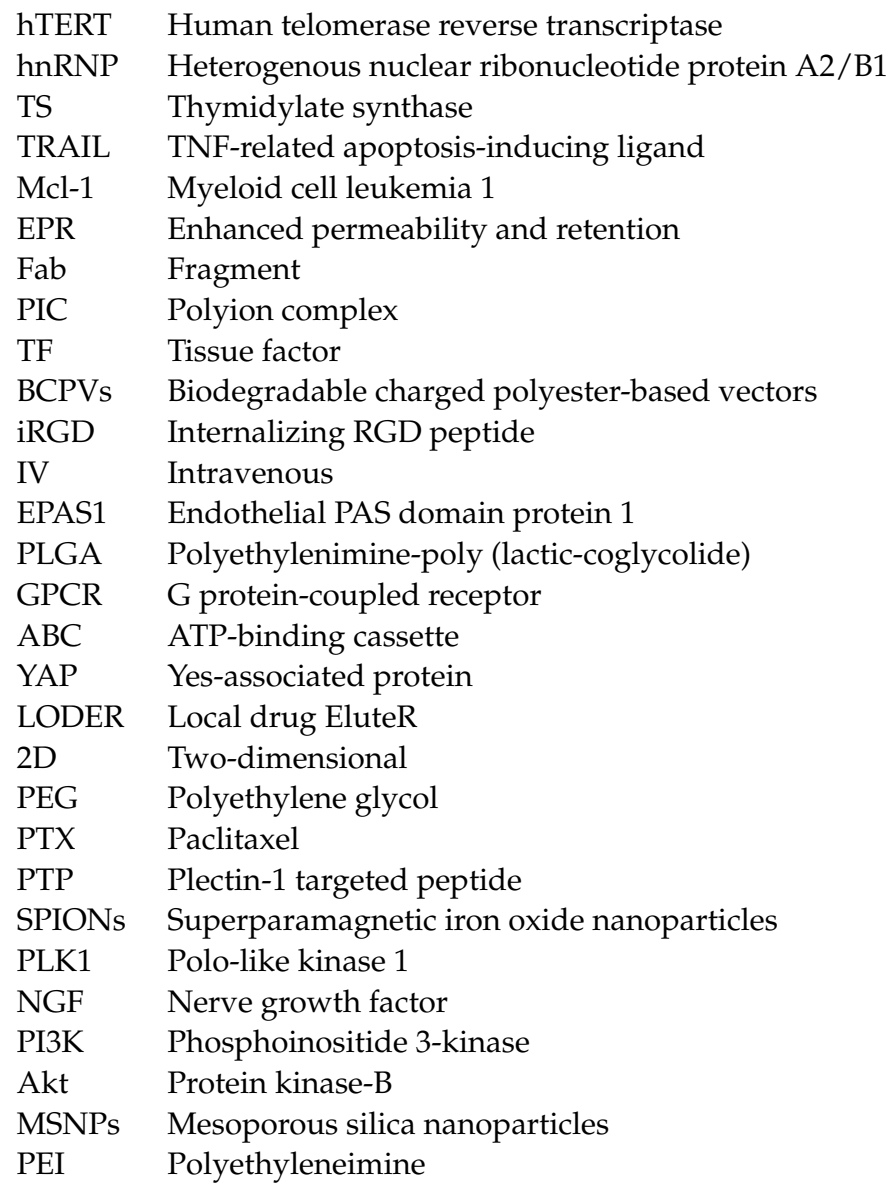

\section{References}

1. Paternoster, S.; Falasca, M. The Intricate Relationship between Diabetes, Obesity and Pancreatic Cancer. Biochim. Biophys. Acta Rev. Cancer 2020, 1873, 188326. [CrossRef]

2. Daoud, A.Z.; Mulholland, E.J.; Cole, G.; McCarthy, H.O. MicroRNAs in pancreatic cancer: Biomarkers, prognostic, and therapeutic modulators. BMC Cancer 2019, 19, 1130. [CrossRef]

3. Siegel, R.L.; Miller, K.D.; Fuchs, H.E.; Jemal, A. Cancer Statistics, 2021. CA Cancer J. Clin. 2021, 71, 7-33. [CrossRef] [PubMed]

4. Ashrafizadeh, M.; Bakhoda, M.R.; Bahmanpour, Z.; Ilkhani, K.; Zarrabi, A.; Makvandi, P.; Khan, H.; Mazaheri, S.; Darvish, M.; Mirzaei, H. Apigenin as Tumor Suppressor in Cancers: Biotherapeutic Activity, Nanodelivery, and Mechanisms with Emphasis on Pancreatic Cancer. Front. Chem. 2020, 8, 829. [CrossRef]

5. Siegel, R.L.; Miller, K.D.; Jemal, A. Cancer Statistics, 2019. CA Cancer J. Clin. 2019, 69, 7-34. [CrossRef] [PubMed]

6. Ilic, M.; Ilic, I. Epidemiology of Pancreatic Cancer. World J. Gastroenterol. 2016, 22, 9694-9705. [CrossRef] [PubMed]

7. Yang, D.; Hu, Z.; Xu, J.; Tang, Y.; Wang, Y.; Cai, Q.; Zhu, Z. MiR-760 Enhances Sensitivity of Pancreatic Cancer Cells to Gemcitabine through Modulating INTEGRIN $\beta 1$. Biosci. Rep. 2019, 39, BSR20192358. [CrossRef] [PubMed]

8. Liu, Y.; Guo, C.; Li, F.; Wu, L. LncRNA LOXL1-AS1/miR-28-5p/SEMA7A Axis Facilitates Pancreatic Cancer Progression. Cell Biochem. Funct. 2020, 38, 58-65. [CrossRef] [PubMed]

9. Gong, Y.; Dai, H.S.; Shu, J.J.; Liu, W.; Bie, P.; Zhang, L.D. LNC00673 Suppresses Proliferation and Metastasis of Pancreatic Cancer via Target miR-504/ HNF1A. J. Cancer 2020, 11, 940-948. [CrossRef] [PubMed]

10. Ercan, G.; Karlitepe, A.; Ozpolat, B. Pancreatic Cancer Stem Cells and Therapeutic Approaches. Anticancer Res. 2017, 37, 2761-2775. [CrossRef]

11. Chiorean, E.G.; Coveler, A.L. Pancreatic Cancer: Optimizing Treatment Options, New, and Emerging Targeted Therapies. Drug Des. Devel. Ther. 2015, 9, 3529-3545. [CrossRef] [PubMed]

12. Jung, Y.Y.; Ko, J.H.; Um, J.Y.; Chinnathambi, A.; Alharbi, S.A.; Sethi, G.; Ahn, K.S. LDL Cholesterol Promotes the Proliferation of Prostate and Pancreatic Cancer Cells by Activating the STAT3 Pathway. J. Cell Physiol. 2021, 236, 5253-5264. [CrossRef] [PubMed]

13. Pandya, G.; Kirtonia, A.; Sethi, G.; Pandey, A.K.; Garg, M. The Implication of Long Non-Coding RNAs in the Diagnosis, Pathogenesis and Drug Resistance of Pancreatic Ductal Adenocarcinoma and Their Possible Therapeutic Potential. Biochim. Biophys. Acta Rev. Cancer 2020, 1874, 188423. [CrossRef]

14. Ashrafizadeh, M.; Ahmadi, Z.; Mohamadi, N.; Zarrabi, A.; Abasi, S.; Dehghannoudeh, G.; Tamaddondoust, R.N.; Khanbabaei, H.; Mohammadinejad, R.; Thakur, V.K. Chitosan-Based Advanced Materials for Docetaxel and Paclitaxel Delivery: Recent Advances and Future Directions in Cancer Theranostics. Int. J. Biol. Macromol. 2020, 145, 282-300. [CrossRef] [PubMed] 
15. Ashrafizadeh, M.; Zarrabi, A.; Hashemi, F.; Zabolian, A.; Saleki, H.; Bagherian, M.; Azami, N.; Bejandi, A.K.; Hushmandi, K.; Ang, H.L. Polychemotherapy with Curcumin and Doxorubicin via Biological Nanoplatforms: Enhancing Antitumor Activity. Pharmaceutics 2020, 12, 1084. [CrossRef]

16. Yao, Y.; Wang, T.; Liu, Y.; Zhang, N. Co-Delivery of Sorafenib and VEGF-siRNA via pH-Sensitive Liposomes for the Synergistic Treatment of Hepatocellular Carcinoma. Artif. Cells Nanomed. Biotechnol. 2019, 47, 1374-1383. [CrossRef]

17. He, Y.; Guo, S.; Wu, L.; Chen, P.; Wang, L.; Liu, Y.; Ju, H. Near-Infrared Boosted ROS Responsive siRNA Delivery and Cancer Therapy with Sequentially Peeled Upconversion Nano-Onions. Biomaterials 2019, 225, 119501. [CrossRef]

18. Wang, D.; Zhang, F.; Gao, G. CRISPR-Based Therapeutic Genome Editing: STRATEGIES and in Vivo Delivery by aav Vectors. Cell 2020, 181, 136-150. [CrossRef] [PubMed]

19. Zhen, S.; Li, X. Liposomal Delivery of CRISPR/Cas9. Cancer Gene Ther. 2020, 27, 515-527. [CrossRef]

20. Mirzaei, S.; Abbaspour, A.; Fallahzadeh, P.; Noori, M.; Hashemi, F.; Hushmandi, K.; Daneshi, S.; Kumar, A.P. Small Interfering RNA (siRNA) to Target Genes and Molecular Pathways in Glioblastoma Therapy: Current Status with an Emphasis on Delivery Systems. Life Sci. 2021, 275, 119368. [CrossRef]

21. Ashrafizade, M.; Delfi, M.; Hashemi, F.; Zabolian, A.; Saleki, H.; Bagherian, M.; Azami, N.; Farahani, M.V.; omid Sharifzadeh, S.; Hamzehlou, S. Biomedical Application of Chitosan-Based Nanoscale Delivery Systems: Potential Usefulness in siRNA Delivery for Cancer Therapy. Carbohydr. Polym. 2021, 260, 117809. [CrossRef]

22. Mirzaei, S.; Gholami, M.H.; Hashemi, F.; Zabolian, A.; Hushmandi, K.; Rahmanian, V.; Entezari, M.; Girish, Y.R.; Kumar, K.S.S.; Aref, A.R. Employing siRNA Tool and Its Delivery Platforms in Suppressing Cisplatin Resistance: Approaching to a New Era of Cancer Chemotherapy. Life Sci. 2021, 277, 119430. [CrossRef]

23. Ashrafizadeh, M.; Zarrabi, A.; Hushmandi, K.; Hashemi, F.; Rahmani Moghadam, E.; Raei, M.; Kalantari, M.; Tavakol, S.; Mohammadinejad, R.; Najafi, M. Progress in Natural Compounds/siRNA Co-Delivery Employing Nanovehicles for Cancer Therapy. ACS Comb. Sci. 2020, 22, 669-700. [CrossRef]

24. Ashrafizadeh, M.; Hushmandi, K.; Rahmani Moghadam, E.; Zarrin, V.; Hosseinzadeh Kashani, S.; Bokaie, S.; Najafi, M.; Tavakol, S.; Mohammadinejad, R.; Nabavi, N. Progress in Delivery of siRNA-Based Therapeutics Employing Nano-Vehicles for Treatment of Prostate Cancer. Bioengineering 2020, 7, 91. [CrossRef]

25. Peer, D.; Karp, J.M.; Hong, S.; Farokhzad, O.C.; Margalit, R.; Langer, R. Nanocarriers as an Emerging Platform for Cancer Therapy. Nat. Nanotechnol. 2007, 2, 751-760. [CrossRef]

26. Rui, Y.; Wilson, D.R.; Choi, J.; Varanasi, M.; Sanders, K.; Karlsson, J.; Lim, M.; Green, J.J. Carboxylated Branched Poly ( $\beta$-Amino ester) Nanoparticles Enable Robust Cytosolic Protein Delivery and CRISPR-Cas9 Gene Editing. Sci. Adv. 2019, 5, eaay3255. [CrossRef] [PubMed]

27. Jubair, L.; Fallaha, S.; McMillan, N.A.J. Systemic Delivery of CRISPR/Cas9 Targeting HPV Oncogenes is Effective at Eliminating Established Tumors. Mol. Ther. 2019, 27, 2091-2099. [CrossRef] [PubMed]

28. Wei, T.; Cheng, Q.; Farbiak, L.; Anderson, D.G.; Langer, R.; Siegwart, D.J. Delivery of Tissue-Targeted Scalpels: Opportunities and Challenges for in Vivo CRISPR/Cas-Based Genome Editing. ACS Nano 2020, 14, 9243-9262. [CrossRef]

29. Yu, Q.; Zhang, B.; Zhou, Y.; Ge, Q.; Chang, J.; Chen, Y.; Zhang, K.; Peng, D.; Chen, W. Co-Delivery of Gambogenic Acid and VEGF-siRNA with Anionic Liposome and Polyethylenimine Complexes to HepG2 Cells. J. Liposome Res. 2019, $29,322-331$. [CrossRef]

30. Vocelle, D.; Chan, C.; Walton, S.P. Endocytosis Controls siRNA Efficiency: Implications for siRNA Delivery Vehicle Design and Cell-Specific Targeting. Nucleic Acid Ther. 2020, 30, 22-32. [CrossRef]

31. Li, S.; Liu, Z.; Ji, F.; Xiao, Z.; Wang, M.; Peng, Y.; Zhang, Y.; Liu, L.; Liang, Z.; Li, F. Delivery of Quantum Dot-siRNA Nanoplexes in SK-N-SH Cells for BACE1 Gene Silencing and Intracellular Imaging. Mol. Ther. Nucleic Acids 2012, 1, 22-32. [CrossRef] [PubMed]

32. Kozielski, K.L.; Ruiz-Valls, A.; Tzeng, S.Y.; Guerrero-Cázares, H.; Rui, Y.; Li, Y.; Vaughan, H.J.; Gionet-Gonzales, M.; Vantucci, C.; Kim, J.; et al. Cancer-Selective Nanoparticles for Combinatorial siRNA Delivery to Primary Human GBM in Vitro and in Vivo. Biomaterials 2019, 209, 79-87. [CrossRef]

33. Kulkarni, J.A.; Darjuan, M.M.; Mercer, J.E.; Chen, S.; van der Meel, R.; Thewalt, J.L.; Tam, Y.Y.C.; Cullis, P.R. On the Formation and morphology of lipid nanoparticles containing ionizable cationic lipids and siRNA. ACS Nano 2018, 12, 4787-4795. [CrossRef]

34. Shaat, H.; Mostafa, A.; Moustafa, M.; Gamal-Eldeen, A.; Emam, A.; El-Hussieny, E.; Elhefnawi, M. Modified gold nanoparticles for Intracellular Delivery of Anti-Liver Cancer siRNA. Int. J. Pharm. 2016, 504, 125-133. [CrossRef]

35. Yamakawa, K.; Nakano-Narusawa, Y.; Hashimoto, N.; Yokohira, M.; Matsuda, Y. Development and Clinical Trials of Nucleic Acid Medicines for Pancreatic Cancer Treatment. Int. J. Mol. Sci. 2019, 20, 4224. [CrossRef] [PubMed]

36. Kurtanich, T.; Roos, N.; Wang, G.; Yang, J.; Wang, A.; Chung, E.J. Pancreatic Cancer Gene Therapy Delivered by Nanoparticles. SLAS Technol. 2019, 24, 151-160. [CrossRef] [PubMed]

37. Takakura, K.; Kawamura, A.; Torisu, Y.; Koido, S.; Yahagi, N.; Saruta, M. The Clinical Potential of Oligonucleotide Therapeutics against Pancreatic Cancer. Int. J. Mol. Sci. 2019, 20, 3331. [CrossRef]

38. Kokkinos, J.; Ignacio, R.M.C.; Sharbeen, G.; Boyer, C.; Gonzales-Aloy, E.; Goldstein, D.; Australian Pancreatic Cancer Genome Initiative, A.; McCarroll, J.A.; Phillips, P.A. Targeting the Undruggable in Pancreatic Cancer Using Nano-Based Gene Silencing Drugs. Biomaterials 2020, 240, 119742. [CrossRef] [PubMed]

39. Sato-Dahlman, M.; Wirth, K.; Yamamoto, M. Role of Gene Therapy in Pancreatic Cancer-A Review. Cancers 2018, 10, 103. [CrossRef] 
40. Liu, Y.; Wu, W.; Wang, Y.; Han, S.; Yuan, Y.; Huang, J.; Shuai, X.; Peng, Z. Recent Development of Gene Therapy for Pancreatic Cancer Using Non-Viral Nanovectors. Biomater. Sci. 2021, 9, 6673-6690. [CrossRef] [PubMed]

41. Galanopoulos, M.; Doukatas, A.; Gkeros, F.; Viazis, N.; Liatsos, C. Room for Improvement in the Treatment of Pancreatic Cancer: Novel Opportunities from Gene Targeted Therapy. World J. Gastroenterol. 2021, 27, 3568-3580. [CrossRef] [PubMed]

42. Kim, H.J.; Kim, A.; Miyata, K.; Kataoka, K. Recent Progress in Development of siRNA Delivery Vehicles for Cancer Therapy. Adv. Drug Deliv. Rev. 2016, 104, 61-77. [CrossRef] [PubMed]

43. Kim, D.H.; Rossi, J.J. Strategies for Silencing Human Disease Using RNA Interference. Nat. Rev. Genet. 2007, 8, 173-184. [CrossRef]

44. Singh, A.; Trivedi, P.; Jain, N.K. Advances in siRNA Delivery in Cancer Therapy. Artif. Cells Nanomed. Biotechnol. 2018, 46, 274-283. [CrossRef]

45. Houseley, J.; Tollervey, D. The Many Pathways of RNA Degradation. Cell 2009, 136, 763-776. [CrossRef]

46. De La Sierra-Gallay, I.; Zig, L.; Jamalli, A.; Putzer, H. Structural Insights into the Dual Activity of RNase. J. Nat. Struct. Mol. Biol. 2008, 15, 206-212. [CrossRef]

47. Mathy, N.; Bénard, L.; Pellegrini, O.; Daou, R.; Wen, T.; Condon, C. 5'-to-3' Exoribonuclease Activity in Bacteria: Role of RNase J1 in rRNA Maturation and 5' Stability of mRNA. Cell 2007, 129, 681-692. [CrossRef]

48. Matranga, C.; Tomari, Y.; Shin, C.; Bartel, D.P.; Zamore, P.D. Passenger-Strand Cleavage Facilitates Assembly of siRNA into Ago2-Containing RNAi Enzyme Complexes. Cell 2005, 123, 607-620. [CrossRef]

49. Tolia, N.H.; Joshua-Tor, L. Slicer and the Argonautes. Nat. Chem. Biol. 2007, 3, 36-43. [CrossRef]

50. Ameres, S.L.; Martinez, J.; Schroeder, R. Molecular Basis for Target RNA Recognition and Cleavage by Human RISC. Cell 2007, 130, 101-112. [CrossRef]

51. Rand, T.A.; Petersen, S.; Du, F.; Wang, X. Argonaute2 Cleaves the Anti-Guide Strand of siRNA during RISC Activation. Cell 2005, 123, 621-629. [CrossRef]

52. Dykxhoorn, D.M.; Lieberman, J. Knocking down Disease with siRNAs. Cell 2006, 126, 231-235. [CrossRef]

53. Novina, C.D.; Sharp, P.A. The RNAi Revolution. Nature 2004, 430, 161-164. [CrossRef] [PubMed]

54. Lingel, A.; Sattler, M. Novel Modes of Protein-RNA Recognition in the RNAi Pathway. Curr. Opin. Struct. Biol. 2005, 15, 107-115. [CrossRef] [PubMed]

55. George, J.; Banik, N.L.; Ray, S.K. Bcl-2 siRNA Augments Taxol Mediated Apoptotic Death in Human Glioblastoma U138MG and U251MG Cells. Neurochem. Res. 2009, 34, 66-78. [CrossRef] [PubMed]

56. Salehi Khesht, A.M.; Karpisheh, V.; Sahami Gilan, P.; Melnikova, L.A.; Olegovna Zekiy, A.; Mohammadi, M.; Hojjat-Farsangi, M.; Majidi Zolbanin, N.; Mahmoodpoor, A.; Hassannia, H.; et al. Blockade of CD73 Using siRNA Loaded Chitosan Lactate Nanoparticles Functionalized with TAT-Hyaluronate Enhances Doxorubicin Mediated Cytotoxicity in Cancer Cells Both In Vitro and In Vivo. Int. J. Biol. Macromol. 2021, 186, 849-863. [CrossRef]

57. Li, Y.; Tan, X.; Liu, X.; Liu, L.; Fang, Y.; Rao, R.; Ren, Y.; Yang, X.; Liu, W. Enhanced Anticancer Effect of Doxorubicin by TPGS-Coated Liposomes with Bcl-2 siRNA-Corona for Dual Suppression of Drug Resistance. Asian J. Pharm. Sci. 2020, 15, 646-660. [CrossRef]

58. Zhang, Y.; Fu, X.; Jia, J.; Wikerholmen, T.; Xi, K.; Kong, Y.; Wang, J.; Chen, H.; Ma, Y.; Li, Z.; et al. Glioblastoma Therapy Using Codelivery of Cisplatin and Glutathione Peroxidase Targeting siRNA from Iron Oxide Nanoparticles. ACS Appl. Mater. Interfaces 2020, 12, 43408-43421. [CrossRef]

59. Patel, V.; Lalani, R.; Vhora, I.; Bardoliwala, D.; Patel, A.; Ghosh, S.; Misra, A. Co-Delivery of Cisplatin and siRNA through Hybrid Nanocarrier Platform for Masking Resistance to Chemotherapy in Lung Cancer. Drug Deliv. Transl. Res. 2020, 11, $2052-2071$. [CrossRef]

60. Lai, Y.; Kong, Z.; Zeng, T.; Xu, S.; Duan, X.; Li, S.; Cai, C.; Zhao, Z.; Wu, W. PARP1-siRNA Suppresses Human Prostate Cancer Cell Growth and Progression. Oncol. Rep. 2018, 39, 1901-1909. [CrossRef]

61. Rebollo, J.; Geliebter, J.; Reyes, N. ESM-1 siRNA Knockdown Decreased Migration and Expression of CXCL3 in Prostate Cancer Cells. Int. J. Biomed. Sci. 2017, 13, 35-42. [PubMed]

62. Birmingham, A.; Anderson, E.M.; Reynolds, A.; Ilsley-Tyree, D.; Leake, D.; Fedorov, Y.; Baskerville, S.; Maksimova, E.; Robinson, K.; Karpilow, J. 3' UTR Seed Matches, But Not Overall Identity, Are Associated with RNAi off-Targets. Nat. Methods. 2006, 3, 199-204. [CrossRef]

63. Ozcan, G.; Ozpolat, B.; Coleman, R.L.; Sood, A.K.; Lopez-Berestein, G. Preclinical and Clinical Development of siRNA-Based Therapeutics. Adv. Drug Deliv. Rev. 2015, 87, 108-119. [CrossRef] [PubMed]

64. Yang, Q.; Humphreys, S.C.; Lade, J.M.; Li, A.P. Prolonged Cultured Human Hepatocytes as an in Vitro Experimental System for the Evaluation of Potency and Duration of Activity of RNA Therapeutics: Demonstration of Prolonged Duration of Gene Silencing Effects of a GalNAc-Conjugated Human Hypoxanthine Phosphoribosyl Transferase (HPRT1) siRNA. Biochem. Pharmacol. 2021, 189, 114374. [CrossRef] [PubMed]

65. Anselmo, A.C.; Mitragotri, S. Nanoparticles in the Clinic. Bioeng. Transl. Med. 2016, 1, 10-29. [CrossRef] [PubMed]

66. Shi, M.; Zhang, J.; Huang, Z.; Chen, Y.; Pan, S.; Hu, H.; Qiao, M.; Chen, D.; Zhao, X. Stimuli-Responsive Release and Efficient siRNA Delivery in Non-Small Cell Lung Cancer by a Poly(l-Histidine)-Based Multifunctional Nanoplatform. J. Mater. Chem. B 2020, 8, 1616-1628. [CrossRef]

67. Li, S.; Saw, P.E.; Lin, C.; Nie, Y.; Tao, W.; Farokhzad, O.C.; Zhang, L.; Xu, X. Redox-Responsive Polyprodrug Nanoparticles for Targeted siRNA Delivery and Synergistic Liver Cancer Therapy. Biomaterials 2020, 234, 119760. [CrossRef] 
68. Lan, B.; Wu, J.; Li, N.; Pan, C.; Yan, L.; Yang, C.; Zhang, L.; Yang, L.; Ren, M. Hyperbranched Cationic Polysaccharide Derivatives for Efficient siRNA Delivery and Diabetic Wound Healing Enhancement. Int. J Biol. Macromol. 2020, 154, 855-865. [CrossRef] [PubMed]

69. Di Silvio, D.; Martínez-Moro, M.; Salvador, C.; de Los Angeles Ramirez, M.; Caceres-Velez, P.R.; Ortore, M.G.; Dupin, D.; Andreozzi, P.; Moya, S.E. Self-Assembly of Poly(Allylamine)/siRNA Nanoparticles, Their Intracellular Fate and siRNA Delivery. J. Colloid Interface Sci. 2019, 557, 757-766. [CrossRef]

70. Karlsson, J.; Rui, Y.; Kozielski, K.L.; Placone, A.L.; Choi, O.; Tzeng, S.Y.; Kim, J.; Keyes, J.J.; Bogorad, M.I.; Gabrielson, K.; et al Engineered Nanoparticles for Systemic siRNA Delivery to Malignant Brain Tumours. Nanoscale 2019, 11, 20045-20057. [CrossRef] [PubMed]

71. Chen, M.; Chen, M.; He, J. Cancer Cell Membrane Cloaking Nanoparticles for Targeted Co-Delivery of Doxorubicin and PD-L1 siRNA. Artif. Cells Nanomed. Biotechnol. 2019, 47, 1635-1641. [CrossRef]

72. Hanurry, E.Y.; Hsu, W.H.; Darge, H.F.; Birhan, Y.S.; Mekonnen, T.W.; Andrgie, A.T.; Chou, H.Y.; Cheng, C.C.; Lai, J.Y.; Tsai, H.C. In vitro siRNA delivery via diethylenetriamine- and tetraethylenepentamine-modified carboxyl group-terminated Poly(amido)amine generation 4.5 dendrimers. Mater. Sci. Eng. C Mater. Biol. Appl. 2020, 106, 110245. [CrossRef]

73. Zou, Y.; Sun, X.; Wang, Y.; Yan, C.; Liu, Y.; Li, J.; Zhang, D.; Zheng, M.; Chung, R.S.; Shi, B. Single siRNA Nanocapsules for Effective siRNA Brain Delivery and Glioblastoma Treatment. Adv. Mater. 2020, 32, e2000416. [CrossRef]

74. Ghaffari, M.; Dehghan, G.; Baradaran, B.; Zarebkohan, A.; Mansoori, B.; Soleymani, J.; Ezzati Nazhad Dolatabadi, J.; Hamblin, M.R. Co-Delivery of Curcumin and Bcl-2 siRNA by PAMAM Dendrimers for Enhancement of the Therapeutic Efficacy in HeLa Cancer Cells. Colloids Surf. B Biointerfaces 2020, 188, 110762. [CrossRef]

75. Mainini, F.; Eccles, M.R. Lipid and Polymer-Based Nanoparticle siRNA Delivery Systems for Cancer Therapy. Molecules 2020, 25, 2692. [CrossRef] [PubMed]

76. Erdene-Ochir, T.; Ganbold, T.; Zandan, J.; Han, S.; Borjihan, G.; Baigude, H. Alkylation Enhances Biocompatibility and siRNA Delivery Efficiency of Cationic Curdlan Nanoparticles. Int. J. Biol. Macromol. 2020, 143, 118-125. [CrossRef]

77. Choi, M.; Jeong, H.; Kim, S.; Kim, M.; Lee, M.; Rhim, T. Targeted Delivery of Chil3/Chil4 siRNA to Alveolar Macrophages Using ternary Complexes Composed of HMG and Oligoarginine Micelles. Nanoscale 2020, 12, 933-943. [CrossRef] [PubMed]

78. Bulbake, U.; Kommineni, N.; Ionov, M.; Bryszewska, M.; Khan, W. Comparison of Cationic Liposome and PAMAM Dendrimer for Delivery of Anti-Plk1 siRNA in Breast Cancer Treatment. Pharm. Dev. Technol. 2020, 25, 9-19. [CrossRef]

79. Zhao, L.; Gu, C.; Gan, Y.; Shao, L.; Chen, H.; Zhu, H. Exosome-Mediated siRNA Delivery to Suppress Postoperative Breast Cancer Metastasis. J. Control. Release 2020, 318, 1-15. [CrossRef] [PubMed]

80. Baran-Rachwalska, P.; Torabi-Pour, N.; Sutera, F.M.; Ahmed, M.; Thomas, K.; Nesbit, M.A.; Welsh, M.; Moore, C.B.T.; Saffie-Siebert, S.R. Topical siRNA Delivery to the Cornea and Anterior Eye by Hybrid Silicon-Lipid Nanoparticles. J. Control. Release 2020, 326, 192-202. [CrossRef]

81. Azambuja, J.H.; Schuh, R.S.; Michels, L.R.; Gelsleichter, N.E.; Beckenkamp, L.R.; Iser, I.C.; Lenz, G.S.; de Oliveira, F.H.; Venturin, G.; Greggio, S.; et al. Nasal Administration of Cationic Nanoemulsions as CD73-siRNA Delivery System for Glioblastoma Treatment: A New Therapeutical Approach. Mol. Neurobiol. 2020, 57, 635-649. [CrossRef]

82. Xia, Y.; Tang, G.; Wang, C.; Zhong, J.; Chen, Y.; Hua, L.; Li, Y.; Liu, H.; Zhu, B. Functionalized Selenium Nanoparticles for Targeted siRNA Delivery Silence Derlin1 and Promote Antitumor Efficacy against Cervical Cancer. Drug Deliv. 2020, 27, 15-25. [CrossRef]

83. Kara, G.; Parlar, A.; Cakmak, M.C.; Cokol, M.; Denkbas, E.B.; Bakan, F. Silencing of Survivin and Cyclin B1 through siRNA-Loaded Arginine Modified Calcium Phosphate Nanoparticles for Non-Small-Cell Lung Cancer Therapy. Colloids Surf. B. Biointerfaces 2020, 196, 111340. [CrossRef]

84. Zhang, C.; Yuan, W.; Wu, Y.; Wan, X.; Gong, Y. Co-Delivery of EGFR and BRD4 siRNA by Cell-Penetrating Peptides-Modified Redox-Responsive Complex in Triple Negative Breast Cancer Cells. Life Sci. 2021, 266, 118886. [CrossRef]

85. Khodaei, M.; Rostamizadeh, K.; Taromchi, A.H.; Monirinasab, H.; Fathi, M. DDAB Cationic Lipid-mPEG, PCL Copolymer Hybrid Nano-Carrier Synthesis and Application for Delivery of siRNA Targeting IGF-1R into Breast Cancer Cells. Clin. Transl. Oncol. 2021, 23, 1167-1178. [CrossRef]

86. Wang, F.; Zhang, Z. Nanoformulation of Apolipoprotein E3-Tagged Liposomal Nanoparticles for the Co-Delivery of KRAS-siRNA and Gemcitabine for Pancreatic Cancer Treatment. Pharm. Res. 2020, 37, 247. [CrossRef] [PubMed]

87. Li, M.; Guo, H.; Wang, Q.; Chen, K.; Marko, K.; Tian, X.; Yang, Y. Pancreatic Stellate Cells Derived Exosomal miR-5703 Promotes Pancreatic Cancer by Downregulating CMTM4 and Activating PI3K/Akt Pathway. Cancer Lett. 2020, 490, 20-30. [CrossRef] [PubMed]

88. Fu, X.; Tang, N.; Xie, W.; Mao, L.; Qiu, Y. Mind Bomb 1 Promotes Pancreatic Cancer Proliferation by Activating $\beta$-Catenin Signaling. J. Nanosci. Nanotechnol. 2020, 20, 7276-7282. [CrossRef] [PubMed]

89. Wang, L.; Gao, P.; Yuan, P.; Zhou, P.; Fan, H.; Lin, X.; Yuan, X.; Zhu, M.; Fan, X.; Lu, Y.; et al. miR-573 Suppresses Pancreatic Cancer Cell Proliferation, Migration, and Invasion through Targeting TSPAN1. Strahlenther. Onkol. 2021, 197, 438-448. [CrossRef]

90. Swami, P.; Thiyagarajan, S.; Vidger, A.; Indurthi, V.S.K.; Vetter, S.W.; Leclerc, E. RAGE up-Regulation Differently Affects Cell Proliferation and Migration in Pancreatic Cancer Cells. Int. J. Mol. Sci. 2020, 21, 7723. [CrossRef]

91. Li, A.; Feng, L.; Niu, X.; Zeng, Q.; Li, B.; You, Z. Downregulation of OIP5-AS1 Affects proNGF-Induced Pancreatic Cancer Metastasis by Inhibiting p75NTR Levels. Aging (Albany NY) 2021, 13, 10688-10702. [CrossRef] [PubMed] 
92. Fofaria, N.M.; Srivastava, S.K. STAT3 Induces Anoikis Resistance, Promotes Cell Invasion and Metastatic Potential in Pancreatic Cancer Cells. Carcinogenesis 2015, 36, 142-150. [CrossRef]

93. Lagadec, C.; Romon, R.; Tastet, C.; Meignan, S.; Com, E.; Page, A.; Bidaux, G.; Hondermarck, H.; Le Bourhis, X. Ku86 Is Important for TrkA Overexpression-Induced Breast Cancer Cell Invasion. Proteomics. Clin. Appl. 2010, 4, 580-590. [CrossRef]

94. Bao, X.; Shi, J.; Xie, F.; Liu, Z.; Yu, J.; Chen, W.; Zhang, Z.; Xu, Q. Proteolytic Release of the p75NTR Intracellular Domain by ADAM10 Promotes Metastasis and Resistance to Anoikis. Cancer Res. 2018, 78, 2262-2276. [CrossRef]

95. Xu, J.; Song, J.; Yang, X.; Guo, J.; Wang, T.; Zhuo, W. ProNGF siRNA inhibits cell proliferation and invasion of pancreatic cancer cells and promotes anoikis. Biomed Pharmacother 2019, 111, 1066-1073. [CrossRef]

96. Ashrafizadeh, M.; Zarrabi, A.; Orouei, S.; Hushmandi, K.; Hakimi, A.; Zabolian, A.; Daneshi, S.; Samarghandian, S.; Baradaran, B.; Najafi, M. MicroRNA-Mediated Autophagy Regulation in Cancer Therapy: The Role in Chemoresistance/Chemosensitivity. Eur. J. Pharmacol. 2021, 892, 173660. [CrossRef] [PubMed]

97. Ashrafizadeh, M.; Ahmadi, Z.; Farkhondeh, T.; Samarghandian, S. Autophagy Regulation Using Luteolin: New Insight into Its Anti-Tumor Activity. Cancer Cell Int. 2020, 20, 537. [CrossRef]

98. Patra, S.; Mishra, S.R.; Behera, B.P.; Mahapatra, K.K.; Panigrahi, D.P.; Bhol, C.S.; Praharaj, P.P.; Sethi, G.; Patra, S.K.; Bhutia, S.K. Autophagy-Modulating Phytochemicals in Cancer Therapeutics: Current Evidences and Future Perspectives. Semin. Cancer Biol. 2020, S1044-1579X(1020)30104-30108. [CrossRef] [PubMed]

99. Nabetani, A.; Koujin, T.; Tsutsumi, C.; Haraguchi, T.; Hiraoka, Y. A Conserved Protein, Nuf2, is Implicated in Connecting the Centromere to the Spindle during Chromosome Segregation: A Link between the Kinetochore Function and the Spindle Checkpoint. Chromosoma 2001, 110, 322-334. [CrossRef]

100. DeLuca, J.G.; Moree, B.; Hickey, J.M.; Kilmartin, J.V.; Salmon, E.D. hNuf2 Inhibition Blocks Stable Kinetochore-Microtubule Attachment and Induces Mitotic Cell Death in HeLa Cells. J. Cell Biol. 2002, 159, 549-555. [CrossRef]

101. Hu, P.; Chen, X.; Sun, J.; Bie, P.; Zhang, L.D. siRNA-Mediated Knockdown against NUF2 Suppresses Pancreatic Cancer Proliferation in Vitro and in Vivo. Biosci. Rep. 2015, 35, e00170. [CrossRef] [PubMed]

102. Wang, L.; Liu, H.L.; Li, Y.; Yuan, P. Proteomic Analysis of Pancreatic Intraepithelial Neoplasia and Pancreatic Carcinoma in Rat Models. World J. Gastroenterol. 2011, 17, 1434. [CrossRef]

103. Yan, Z.; Kim, Y.S.; Jetten, A.M. RAP80, a Novel Nuclear Protein That Interacts With the Retinoid-Related Testis-Associated Receptor. J. Biol. Chem. 2002, 277, 32379-32388. [CrossRef]

104. Di Fiore, P.P.; Polo, S.; Hofmann, K. When Ubiquitin Meets Ubiquitin Receptors: A Signalling Connection. Nat. Rev. Mol. Cell Biol. 2003, 4, 491-497. [CrossRef]

105. Hoeller, D.; Crosetto, N.; Blagoev, B.; Raiborg, C.; Tikkanen, R.; Wagner, S.; Kowanetz, K.; Breitling, R.; Mann, M.; Stenmark, H. Regulation of Ubiquitin-Binding Proteins by Monoubiquitination. Nat. Cell Biol. 2006, 8, 163-169. [CrossRef]

106. Yan, J.; Kim, Y.S.; Yang, X.P.; Li, L.P.; Liao, G.; Xia, F.; Jetten, A.M. The Ubiquitin-Interacting Motif-Containing Protein RAP80 Interacts with BRCA1 and Functions in DNA Damage Repair Response. Cancer Res. 2007, 67, 6647-6656. [CrossRef]

107. Wang, B.; Matsuoka, S.; Ballif, B.A.; Zhang, D.; Smogorzewska, A.; Gygi, S.P.; Elledge, S.J. Abraxas and RAP80 Form a BRCA1 Protein Complex Required for the DNA Damage Response. Science 2007, 316, 1194-1198. [CrossRef]

108. Kim, H.; Chen, J.; Yu, X. Ubiquitin-Binding Protein RAP80 Mediates BRCA1-Dependent DNA Damage Response. Science 2007, 316, 1202-1205. [CrossRef] [PubMed]

109. Li, Y.; Gu, W.J.; Liu, H.L. Induction of Pancreatic Cancer Cell Apoptosis and Enhancement of Gemcitabine Sensitivity by RAP80 siRNA. Dig. Dis. Sci. 2012, 57, 2072-2078. [CrossRef] [PubMed]

110. Yang, X.; Lu, Y.; Hang, J.; Zhang, J.; Zhang, T.; Huo, Y.; Liu, J.; Lai, S.; Luo, D.; Wang, L.; et al. Lactate-Modulated Immunosuppression of Myeloid-Derived Suppressor Cells Contributes to the Radioresistance of Pancreatic Cancer. Cancer Immunol. Res. 2020, 8, 1440-1451. [CrossRef]

111. Liu, Y.F.; Luo, D.; Li, X.; Li, Z.Q.; Yu, X.; Zhu, H.W. PVT1 Knockdown Inhibits Autophagy and Improves Gemcitabine Sensitivity by Regulating the MiR-143/HIF-1 $\alpha$ /VMP1 Axis in Pancreatic Cancer. Pancreas 2021, 50, 227-234. [CrossRef] [PubMed]

112. Liu, A.; Xu, J. Circ_03955 Promotes Pancreatic Cancer Tumorigenesis and Warburg Effect by Targeting the miR-3662/HIF-1 $\alpha$ Axis. Clin. Transl. Oncol. 2021, 23, 1905-1914. [CrossRef] [PubMed]

113. Chen, C.; Yu, Z. siRNA Targeting HIF-1alpha Induces Apoptosis of Pancreatic Cancer Cells through NF-kappaB-Independent and-Dependent Pathways under Hypoxic Conditions. Anticancer Res. 2009, 29, 1367-1372.

114. Yan, C.Q.; Zhao, Y.P. The Significance of VEGF siRNA and bFGF siRNA in Invasion and Proliferation of Pancreatic Carcinoma cell. Zhonghua Wai Ke Za Zhi 2010, 48, 610-614. [PubMed]

115. Xu, M.; Gao, J.; Du, Y.Q.; Gao, D.J.; Zhang, Y.Q.; Li, Z.S.; Zhang, Y.L.; Gong, Y.F.; Xu, P. Reduction of Pancreatic Cancer Cell Viability and Induction of Apoptosis Mediated by siRNA Targeting DNMT1 through Suppression of Total DNA Methyltransferase Activity. Mol. Med. Rep. 2010, 3, 699-704. [CrossRef]

116. Boyer, P.L.; Colmenares, C.; Stavnezer, E.; Hughes, S.H. Sequence and Biological Activity of Chicken snoN cDNA Clones. Oncogene 1993, 8, 457-466.

117. Pearson-White, S.; Crittenden, R. Proto-Oncogene Sno Expression, Alternative Isoforms and Immediate Early Serum Response. Nucleic Acids Res. 1997, 25, 2930-2937. [CrossRef] 
118. Imoto, I.; Pimkhaokham, A.; Fukuda, Y.; Yang, Z.Q.; Shimada, Y.; Nomura, N.; Hirai, H.; Imamura, M.; Inazawa, J. SNO is a Probable Target for Gene Amplification at 3q26 in Squamous-Cell Carcinomas of the Esophagus. Biochem. Biophys. Res. Commun. 2001, 286, 559-565. [CrossRef] [PubMed]

119. Bonni, S.; Wang, H.R.; Causing, C.G.; Kavsak, P.; Stroschein, S.L.; Luo, K.; Wrana, J.L. TGF-Beta Induces Assembly of a Smad2-Smurf2 Ubiquitin Ligase Complex that Targets SnoN for Degradation. Nat. Cell Biol. 2001, 3, 587-595. [CrossRef]

120. Stroschein, S.L.; Wang, W.; Zhou, S.; Zhou, Q.; Luo, K. Negative Feedback Regulation of TGF-Beta Signaling by the SnoN Oncoprotein. Science 1999, 286, 771-774. [CrossRef]

121. Liu, C.; Zhang, H.; Zang, X.; Wang, C.; Kong, Y.; Zhang, H. The Influence of SnoN Gene Silencing by siRNA on the Cell Proliferation and Apoptosis of Human Pancreatic Cancer Cells. Diagn. Pathol. 2015, 10, 30. [CrossRef] [PubMed]

122. Ocker, M.; Neureiter, D.; Lueders, M.; Zopf, S.; Ganslmayer, M.; Hahn, E.G.; Herold, C.; Schuppan, D. Variants of bcl-2 Specific siRNA for Silencing Antiapoptotic bcl-2 in Pancreatic Cancer. Gut 2005, 54, 1298-1308. [CrossRef] [PubMed]

123. Fry, A.M.; Meraldi, P.; Nigg, E.A. A Centrosomal Function for the Human Nek2 Protein Kinase, a Member of the NIMA Family of Cell Cycle Regulators. EMBO J. 1998, 17, 470-481. [CrossRef] [PubMed]

124. Hayward, D.G.; Fry, A.M. Nek2 Kinase in Chromosome Instability and Cancer. Cancer Lett. 2006, 237, 155-166. [CrossRef]

125. Zhang, X.; Huang, X.; Xu, J.; Li, E.; Lao, M.; Tang, T.; Zhang, G.; Guo, C.; Zhang, X.; Chen, W.; et al. NEK2 Inhibition Triggers Anti-Pancreatic Cancer Immunity by Targeting PD-L1. Nat. Commun. 2021, 12, 4536. [CrossRef]

126. Kokuryo, T.; Hibino, S.; Suzuki, K.; Watanabe, K.; Yokoyama, Y.; Nagino, M.; Senga, T.; Hamaguchi, M. Nek2 siRNA Therapy Using a Portal Venous Port-Catheter System for Liver Metastasis in Pancreatic Cancer. Cancer Sci. 2016, 107, 1315-1320. [CrossRef]

127. Li, C.; Ge, M.; Chen, D.; Sun, T.; Jiang, H.; Xie, Y.; Lu, H.; Zhang, B.; Han, L.; Chen, J.; et al. RPL21 siRNA blocks proliferation in Pancreatic Cancer Cells by Inhibiting DNA Replication and Inducing G1 Arrest and Apoptosis. Front. Oncol. 2020, 10, 1730. [CrossRef]

128. Yu, Q.; Qiu, Y.; Chen, X.; Wang, X.; Mei, L.; Wu, H.; Liu, K.; Liu, Y.; Li, M.; Zhang, Z.; et al. Chemotherapy Priming of the Pancreatic Tumor Microenvironment Promotes Delivery and Anti-Metastasis Efficacy of Intravenous Low-Molecular-Weight Heparin-Coated lipid-siRNA Complex. Theranostics 2019, 9, 355-368. [CrossRef]

129. Merarchi, M.; Sethi, G.; Shanmugam, M.K.; Fan, L.; Arfuso, F.; Ahn, K.S. Role of Natural Products in Modulating Histone Deacetylases in Cancer. Molecules 2019, 24, 1047. [CrossRef]

130. Wang, L.; Syn, N.L.; Subhash, V.V.; Any, Y.; Thuya, W.L.; Cheow, E.S.H.; Kong, L.; Yu, F.; Peethala, P.C.; Wong, A.L.; et al. PanHDAC Inhibition by Panobinostat Mediates Chemosensitization to Carboplatin in Non-Small Cell Lung Cancer via Attenuation of EGFR Signaling. Cancer Lett. 2018, 417, 152-160. [CrossRef]

131. Zhang, Y.; LeRoy, G.; Seelig, H.P.; Lane, W.S.; Reinberg, D. The Dermatomyositis-Specific Autoantigen Mi2 is a Component of a Complex Containing Histone Deacetylase and Nucleosome Remodeling Activities. Cell 1998, 95, 279-289. [CrossRef]

132. McKinsey, T.A.; Zhang, C.L.; Lu, J.; Olson, E.N. Signal-Dependent Nuclear Export of a Histone Deacetylase Regulates Muscle Differentiation. Nature 2000, 408, 106-111. [CrossRef]

133. Shanmugam, M.K.; Arfuso, F.; Arumugam, S.; Chinnathambi, A.; Jinsong, B.; Warrier, S.; Wang, L.Z.; Kumar, A.P.; Ahn, K.S.; Sethi, G.; et al. Role of Novel Histone Modifications in Cancer. Oncotarget 2018, 9, 11414-11426. [CrossRef]

134. Johnstone, R.W. Histone-Deacetylase Inhibitors: Novel Drugs for the Treatment of Cancer. Nat. Rev. Drug Discov. 2002, 1, 287-299. [CrossRef] [PubMed]

135. Ng, H.H.; Bird, A. Histone Deacetylases: Silencers For hire. Trends Biochem. Sci. 2000, 25, 121-126. [CrossRef]

136. Sixto-López, Y.; Gómez-Vidal, J.A.; de Pedro, N.; Bello, M.; Rosales-Hernández, M.C.; Correa-Basurto, J. Hydroxamic Acid Derivatives as HDAC1, HDAC6 and HDAC8 Inhibitors with Antiproliferative Activity in Cancer Cell Lines. Sci. Rep. 2020, 10, 10462. [CrossRef] [PubMed]

137. Zhu, S.; He, C.; Deng, S.; Li, X.; Cui, S.; Zeng, Z.; Liu, M.; Zhao, S.; Chen, J.; Jin, Y.; et al. MiR-548an, Transcriptionally Downregulated by HIF1 $\alpha /$ HDAC1, Suppresses Tumorigenesis of Pancreatic Cancer by Targeting Vimentin Expression. Mol. Cancer Ther. 2016, 15, 2209-2219. [CrossRef] [PubMed]

138. Aghdassi, A.; Sendler, M.; Guenther, A.; Mayerle, J.; Behn, C.O.; Heidecke, C.D.; Friess, H.; Büchler, M.; Evert, M.; Lerch, M.M.; et al. Recruitment of Histone Deacetylases HDAC1 and HDAC2 by the Transcriptional Repressor ZEB1 Downregulates E-Cadherin Expression in Pancreatic Cancer. Gut 2012, 61, 439-448. [CrossRef]

139. Gao, D.J.; Xu, M.; Zhang, Y.Q.; Du, Y.Q.; Gao, J.; Gong, Y.F.; Man, X.H.; Wu, H.Y.; Jin, J.; Xu, G.M.; et al. Upregulated Histone Deacetylase 1 Expression in Pancreatic Ductal Adenocarcinoma and Specific siRNA Inhibits the Growth of Cancer Cells. Pancreas 2010, 39, 994-1001. [CrossRef]

140. Meng, L.D.; Shi, G.D.; Ge, W.L.; Huang, X.M.; Chen, Q.; Yuan, H.; Wu, P.F.; Lu, Y.C.; Shen, P.; Zhang, Y.H.; et al. Linc01232 Promotes the Metastasis of Pancreatic Cancer by Suppressing the Ubiquitin-Mediated Degradation of HNRNPA2B1 and Activating the A-Raf-induced MAPK/ERK Signaling Pathway. Cancer Lett. 2020, 494, 107-120. [CrossRef] [PubMed]

141. Geng, Y.; Fan, J.; Chen, L.; Zhang, C.; Qu, C.; Qian, L.; Chen, K.; Meng, Z.; Chen, Z.; Wang, P. A Notch-Dependent Inflammatory Feedback Circuit between Macrophages and Cancer Cells Regulates Pancreatic Cancer Metastasis. Cancer Res. 2021, 81, 64-76. [CrossRef]

142. Lee, J.H.; Chiang, S.Y.; Nam, D.; Chung, W.S.; Lee, J.; Na, Y.S.; Sethi, G.; Ahn, K.S. Capillarisin Inhibits Constitutive and Inducible STAT3 Activation through Induction of SHP-1 and SHP-2 Tyrosine Phosphatases. Cancer Lett. 2014, 345, 140-148. [CrossRef] 
143. Kim, S.M.; Lee, J.H.; Sethi, G.; Kim, C.; Baek, S.H.; Nam, D.; Chung, W.S.; Kim, S.H.; Shim, B.S.; Ahn, K.S. Bergamottin, a Natural Furanocoumarin Obtained from Grapefruit Juice Induces Chemosensitization and Apoptosis through the Inhibition of STAT3 Signaling Pathway IN Tumor Cells. Cancer Lett. 2014, 354, 153-163. [CrossRef]

144. Zhang, J.; Ahn, K.S.; Kim, C.; Shanmugam, M.K.; Siveen, K.S.; Arfuso, F.; Samym, R.P.; Deivasigamanim, A.; Lim, L.H.; Wang, L.; et al. Nimbolide-Induced Oxidative Stress Abrogates STAT3 Signaling Cascade and Inhibits Tumor Growth in Transgenic Adenocarcinoma of Mouse Prostate Model. Antioxid. Redox. Signal 2016, 24, 575-589. [CrossRef]

145. Fang, D.; Zhang, C.; Xu, P.; Liu, Y.; Mo, X.; Sun, Q.; Abdelatty, A.; Hu, C.; Xu, H.; Zhou, G.; et al. S100A16 Promotes Metastasis and Progression of Pancreatic Cancer through FGF19-Mediated AKT and ERK1/2 Pathways. Cell Biol. Toxicol. 2021, 37, 555-571. [CrossRef]

146. Wang, C.; Zhang, T.; Liao, Q.; Dai, M.; Guo, J.; Yang, X.; Tan, W.; Lin, D.; Wu, C.; Zhao, Y. Metformin Inhibits Pancreatic Cancer Metastasis Caused by SMAD4 Deficiency and Consequent HNF4G Upregulation. Protein Cell 2021, 12, 128-144. [CrossRef] [PubMed]

147. Xu, S.; Lei, S.L.; Liu, K.J.; Yi, S.G.; Yang, Z.L.; Yao, H.L. circSFMBT1 Promotes Pancreatic Cancer Growth and Metastasis via Targeting miR-330-5p/PAK1 Axis. Cancer Gene Ther. 2021, 28, 234-249. [CrossRef] [PubMed]

148. Yarla, N.S.; Bishayee, A.; Sethi, G.; Reddanna, P.; Kalle, A.M.; Dhananjaya, B.L.; Dowluru, K.S.; Chintala, R.; Duddukuri, G.R. Targeting Arachidonic Acid Pathway by Natural Products for Cancer Prevention and Therapy. Semin. Cancer Biol. 2016, 40-41, 48-81. [CrossRef] [PubMed]

149. Shanmugam, M.K.; Ong, T.H.; Kumar, A.P.; Lun, C.K.; Ho, P.C.; Wong, P.T.; Hui, K.M.; Sethi, G. Ursolic Acid Inhibits the Initiation, Progression of Prostate Cancer and Prolongs the Survival of TRAMP Mice by Modulating Pro-Inflammatory Pathways. PLoS ONE 2012, 7, e32476. [CrossRef] [PubMed]

150. Li, F.; Shanmugam, M.K.; Chen, L.; Chatterjee, S.; Basha, J.; Kumar, A.P.; Kundu, T.K.; Sethi, G. Garcinol, a Polyisoprenylated Benzophenone Modulates Multiple Proinflammatory Signaling Cascades Leading to the Suppression of Growth and Survival of Head and Neck Carcinoma. Cancer Prev. Res. 2013, 6, 843-854. [CrossRef] [PubMed]

151. Hu, H.; Han, T.; Zhuo, M.; Wu, L.L.; Yuan, C.; Wu, L.; Lei, W.; Jiao, F.; Wang, L.W. Elevated COX-2 Expression Promotes Angiogenesis through EGFR/p38-MAPK/Sp1-Dependent Signalling in Pancreatic Cancer. Sci. Rep. 2017, 7, 470. [CrossRef] [PubMed]

152. Matsubayashi, H.; Infante, J.R.; Winter, J.; Klein, A.P.; Schulick, R.; Hruban, R.; Visvanathan, K.; Goggins, M. Tumor COX-2 Expression and Prognosis of Patients with Resectable Pancreatic Cancer. Cancer Biol. Ther. 2007, 6, 1569-1575. [CrossRef]

153. Eibl, G.; Takata, Y.; Boros, L.G.; Liu, J.; Okada, Y.; Reber, H.A.; Hines, O.J. Growth Stimulation of COX-2-Negative Pancreatic Cancer by a Selective COX-2 Inhibitor. Cancer Res. 2005, 65, 982-990.

154. Shanmugam, M.K.; Warrier, S.; Kumar, A.P.; Sethi, G.; Arfuso, F. Potential Role of Natural Compounds as Anti-Angiogenic Agents in Cancer. Curr. Vasc. Pharmacol. 2017, 15, 503-519. [CrossRef] [PubMed]

155. Zhong, Y.; Xia, Z.; Liu, J.; Lin, Y.; Zan, H. The Effects of Cyclooxygenase-2 Gene Silencing by siRNA on Cell Proliferation, Cell Apoptosis, Cell Cycle and Tumorigenicity of Capan-2 Human Pancreatic Cancer Cells. Oncol. Rep. 2012, 27, 1003-1010. [CrossRef]

156. Jung, Y.Y.; Lee, J.H.; Nam, D.; Narula, A.S.; Namjoshi, O.A.; Blough, B.E.; Um, J.Y.; Sethi, G.; Ahn, K.S. Anti-Myeloma Effects of Icariin are Mediated through the Attenuation of JAK/STAT3-Dependent Signaling Cascade. Front. Pharmacol. 2018,9 , 531. [CrossRef]

157. Arora, L.; Kumar, A.P.; Arfuso, F.; Chng, W.J.; Sethi, G. The Role of Signal Transducer and Activator of Transcription 3 (Stat3) and Its Targeted Inhibition in Hematological Malignancies. Cancers (Basel) 2018, 10, 327. [CrossRef]

158. Kim, C.; Lee, S.G.; Yang, W.M.; Arfuso, F.; Um, J.Y.; Kumar, A.P.; Bian, J.; Sethi, G.; Ahn, K.S. Formononetin-induced Oxidative Stress Abrogates the Activation of STAT3/5 Signaling Axis and Suppresses the Tumor Growth in Multiple Myeloma Preclinical Model. Cancer Lett. 2018, 431, 123-141. [CrossRef] [PubMed]

159. Ma, H.; Zhang, J.; Zhou, L.; Wen, S.; Tang, H.Y.; Jiang, B.; Zhang, F.; Suleman, M.; Sun, D.; Chen, A.; et al. c-Src Promotes Tumorigenesis and Tumor Progression by Activating PFKFB3. Cell Rep. 2020, 30, 4235-4249.e6. [CrossRef] [PubMed]

160. Tsuboi, Y.; Oyama, M.; Kozuka-Hata, H.; Ito, A.; Matsubara, D.; Murakami, Y. CADM1 Suppresses c-Src Activation by Binding with Cbp on Membrane Lipid Rafts and Intervenes Colon Carcinogenesis. Biochem. Biophys. Res. Commun. 2020, 529, 854-860. [CrossRef]

161. Mayoral-Varo, V.; Calcabrini, A.; Sánchez-Bailón, M.P.; Martínez-Costa, Ó.H.; González-Páramos, C.; Ciordia, S.; Hardisson, D.; Aragón, J.J.; Fernández-Moreno, M.; Martín-Pérez, J. c-Src Functionality Controls self-Renewal and Glucose Metabolism in MCF7 Breast Cancer Stem Cells. PLoS ONE 2020, 15, e0235850. [CrossRef] [PubMed]

162. Zhang, S.; Li, G.; Liu, C.; Lu, S.; Jing, Q.; Chen, X.; Zheng, H.; Ma, H.; Zhang, D.; Ren, S.; et al. miR-30e-5p Represses Angiogenesis and Metastasis by Directly Targeting AEG-1 in Squamous Cell Carcinoma of the Head and Neck. Cancer Sci. 2020, 111, 356-368. [CrossRef] [PubMed]

163. Chen, R.Y.; Yen, C.J.; Liu, Y.W.; Guo, C.G.; Weng, C.Y.; Lai, C.H.; Wang, J.M.; Lin, Y.J.; Hung, L.Y. CPAP Promotes Angiogenesis and Metastasis by Enhancing STAT3 Activity. Cell Death Differ. 2020, 27, 1259-1273. [CrossRef] [PubMed]

164. Shanmugam, M.K.; Ahn, K.S.; Hsu, A.; Woo, C.C.; Yuan, Y.; Tan, K.H.B.; Chinnathambi, A.; Alahmadi, T.A.; Alharbi, S.A.; Koh, A.P.F.; et al. Thymoquinone Inhibits Bone Metastasis of Breast Cancer Cells through Abrogation of the CXCR4 Signaling Axis. Front. Pharmacol. 2018, 9, 1294. [CrossRef] 
165. Zhao, X.; Li, D.C.; Zhao, H.; Li, Z.; Wang, J.X.; Zhu, D.M.; Zhou, J.; Cen, J.N. A Study of the Suppressive Effect on Human Pancreatic Adenocarcinoma Cell Proliferation and Angiogenesis by Stable Plasmid-Based siRNA Silencing of c-Src Gene Expression. Oncol. Rep. 2012, 27, 628-636. [CrossRef] [PubMed]

166. Ashrafizadeh, M.; Najafi, M.; Orouei, S.; Zabolian, A.; Saleki, H.; Azami, N.; Sharifi, N.; Hushmandi, K.; Zarrabi, A.; Ahn, K.S. Resveratrol Modulates Transforming Growth Factor-Beta (tgf- $\beta$ ) Signaling Pathway for Disease Therapy: A New Insight into Its Pharmacological Activities. Biomedicines 2020, 8, 261. [CrossRef] [PubMed]

167. Ashrafizadeh, M.; Zarrabi, A.; Hushmandi, K.; Zarrin, V.; Moghadam, E.R.; Hashemi, F.; Makvandi, P.; Samarghandian, S.; Khan, H.; Hashemi, F. Toward Regulatory Effects of Curcumin on Transforming Growth Factor-Beta across Different Diseases: A Review. Front. Pharmacol. 2020, 11, 1785. [CrossRef]

168. Yoshimoto, S.; Tanaka, F.; Morita, H.; Hiraki, A.; Hashimoto, S. Hypoxia-Induced HIF-1 $\alpha$ and ZEB1 Are Critical for the Malignant Transformation of Ameloblastoma via TGF- $\beta$-Dependent EMT. Cancer Med. 2019, 8, 7822-7832. [CrossRef]

169. Cheng, J.T.; Wang, L.; Wang, H.; Tang, F.R.; Cai, W.Q.; Sethi, G.; Xin, H.W.; Ma, Z. Insights into Biological Role of LncRNAs in Epithelial-Mesenchymal Transition. Cells 2019, 8, 1178. [CrossRef] [PubMed]

170. Lee, J.H.; Chinnathambi, A.; Alharbi, S.A.; Shair, O.H.M.; Sethi, G.; Ahn, K.S. Farnesol Abrogates Epithelial to Mesenchymal Transition Process through Regulating Akt/mTOR Pathway. Pharmacol. Res. 2019, 150, 104504. [CrossRef] [PubMed]

171. Yoneyama, M.; Fujita, T. RNA Recognition and Signal Transduction by RIG-I-like Receptors. Immunol. Rev. 2009, 227, 54-65. [CrossRef]

172. Besch, R.; Poeck, H.; Hohenauer, T.; Senft, D.; Häcker, G.; Berking, C.; Hornung, V.; Endres, S.; Ruzicka, T.; Rothenfusser, S.; et al. Proapoptotic Signaling Induced by RIG-I and MDA-5 Results in Type I Interferon-Independent Apoptosis in Human Melanoma Cells. J. Clin. Investig. 2009, 119, 2399-2411. [CrossRef] [PubMed]

173. Poeck, H.; Besch, R.; Maihoefer, C.; Renn, M.; Tormo, D.; Morskaya, S.S.; Kirschnek, S.; Gaffal, E.; Landsberg, J.; Hellmuth, J. 5'-Triphosphate-siRNA: Turning Gene Silencing and Rig-I Activation against Melanoma. Nat. Med. 2008, 14, 1256-1263. [CrossRef] [PubMed]

174. Ellermeier, J.; Wei, J.; Duewell, P.; Hoves, S.; Stieg, M.R.; Adunka, T.; Noerenberg, D.; Anders, H.J.; Mayr, D.; Poeck, H.; et al. Therapeutic Efficacy of Bifunctional siRNA Combining TGF- $\beta 1$ Silencing with RIG-I Activation in Pancreatic Cancer. Cancer Res. 2013, 73, 1709-1720. [CrossRef] [PubMed]

175. Schnurr, M.; Duewell, P. Breaking Tumor-Induced Immunosuppression with $5^{\prime}$-Triphosphate siRNA Silencing TGF $\beta$ and Activating RIG-I. Oncoimmunology 2013, 2, e24170. [CrossRef] [PubMed]

176. Ruan, Z.; Liang, M.; Shang, L.; Lai, M.; Deng, X.; Su, X. Shikonin-Mediated PD-L1 Degradation Suppresses Immune Evasion in Pancreatic Cancer by Inhibiting NF-кB/STAT3 and NF-кB/CSN5 Signaling Pathways. Pancreatology 2021, 21, 630-664. [CrossRef] [PubMed]

177. Ashrafizadeh, M.; Zarrabi, A.; Hushmandi, K.; Zarrin, V.; Moghadam, E.R.; Zabolian, A.; Tavakol, S.; Samarghandian, S.; Najafi, M. PD-1/PD-L1 axis regulation in cancer therapy: The role of long non-coding RNAs and microRNAs. Life Sci. 2020, $256,117899$. [CrossRef] [PubMed]

178. Manu, K.A.; Shanmugam, M.K.; Ramachandran, L.; Li, F.; Siveen, K.S.; Chinnathambi, A.; Zayed, M.E.; Alharbi, S.A.; Arfuso, F.; Kumar, A.P.; et al. Isorhamnetin Augments the Anti-Tumor Effect of Capecitabine through the Negative Regulation of NF- $\mathrm{kB}$ Signaling Cascade in Gastric Cancer. Cancer Lett. 2015, 363, 28-36. [CrossRef] [PubMed]

179. Manu, K.A.; Shanmugam, M.K.; Li, F.; Chen, L.; Siveen, K.S.; Ahn, K.S.; Kumar, A.P.; Sethi, G. Simvastatin Sensitizes Human Gastric Cancer Xenograft in Nude Mice to Capecitabine by Suppressing Nuclear Factor-Kappa B-Regulated Gene Products. J. Mol. Med. (Berl) 2014, 92, 267-276. [CrossRef] [PubMed]

180. Chen, C.; Tang, P.; Yue, J.; Ren, P.; Liu, X.; Zhao, X.; Yu, Z. Effect of siRNA Targeting HIF-1alpha Combined L-Ascorbate on Biological Behavior of Hypoxic MiaPaCa2 Cells. Technol. Cancer Res. Treat 2009, 8, 235-240. [CrossRef]

181. Xie, W.; Chu, M.; Song, G.; Zuo, Z.; Han, Z.; Chen, C.; Li, Y.; Wang, Z.W. Emerging Roles of Long Noncoding RNAs in Chemoresistance of Pancreatic Cancer. Semin. Cancer Biol. 2020, S1044-1579X(1020)30222-30224. [CrossRef] [PubMed]

182. Gao, Z.; Wu, J.; Wu, X.; Zheng, J.; Ou, Y. SRPX2 Boosts Pancreatic Cancer Chemoresistance by Activating PI3K/AKT Axis. Open Med. (Wars) 2020, 15, 1072-1082. [CrossRef] [PubMed]

183. Chen, H.; Zhu, X.; Sun, R.; Ma, P.; Zhang, E.; Wang, Z.; Fan, Y.; Zhou, G.; Mao, R. Ubiquitin-Specific Protease 7 Is a Druggable Target That Is Essential for Pancreatic Cancer Growth And Chemoresistance. Investig. New Drugs 2020, 38, 1707-1716. [CrossRef] [PubMed]

184. Elledge, S.J.; Zhou, Z.; Allen, J.B. Ribonucleotide Reductase: Regulation, Regulation, Regulation. Trends Biochem. Sci. 1992, 17, 119-123. [CrossRef]

185. Youns, M.; Askoura, M.; Abbas, H.A.; Attia, G.H.; Khayyat, A.N.; Goda, R.M.; Almalki, A.J.; Khafagy, E.S.; Hegazy, W.A.H. Celastrol Modulates Multiple Signaling Pathways to Inhibit Proliferation of Pancreatic Cancer via DDIT3 and ATF3 up-Regulation and RRM2 and MCM4 Down-Regulation. Onco Targets Ther. 2021, 14, 3849-3860. [CrossRef]

186. Zheng, S.; Wang, X.; Weng, Y.H.; Jin, X.; Ji, J.L.; Guo, L.; Hu, B.; Liu, N.; Cheng, Q.; Zhang, J.; et al. siRNA Knockdown of RRM2 Effectively Suppressed Pancreatic Tumor Growth Alone or Synergistically with Doxorubicin. Mol. Ther. Nucleic Acids 2018, 12, 805-816. [CrossRef]

187. Guo, H.; Liu, F.; Yang, S.; Xue, T. Emodin Alleviates Gemcitabine Resistance in Pancreatic Cancer by Inhibiting MDR1/PGlycoprotein and MRPs Expression. Oncol Lett. 2020, 20, 167. [CrossRef] 
188. Tan, J.; Zhou, X.; Zhu, H. hTERT-siRNA Could Potentiate the Cytotoxic Effect of Gemcitabine to Pancreatic Cancer cells Bxpc-3. Exp. Clin. Transplant. 2012, 10, 386-393. [CrossRef] [PubMed]

189. Zhong, Y.Q.; Xia, Z.S.; Fu, Y.R.; Zhu, Z.H. Knockdown of hTERT by SiRNA Suppresses Growth of Capan-2 Human Pancreatic Cancer Cell via the Inhibition of Expressions of Bcl-2 and COX-2. J. Dig. Dis. 2010, 11, 176-184. [CrossRef]

190. Ashrafizadeh, M.; Zarrabi, A.; Hushmandi, K.; Kalantari, M.; Mohammadinejad, R.; Javaheri, T.; Sethi, G. Association of the Epithelial-Mesenchymal Transition (EMT) with Cisplatin Resistance. Int. J. Mol. Sci. 2020, 21, 4002. [CrossRef]

191. Mirzaei, S.; Gholami, M.H.; Hashemi, F.; Zabolian, A.; Farahani, M.V.; Hushmandi, K.; Zarrabi, A.; Goldman, A.; Ashrafizadeh, M.; Orive, G. Advances in Understanding the Role of P-gp in Doxorubicin Resistance: Molecular Pathways, Therapeutic Strategies, and Prospects. Drug Discov. Today 2021, S1359-6446(21)00428-1. [CrossRef]

192. Paskeh, M.D.A.; Mirzaei, S.; Orouei, S.; Zabolian, A.; Saleki, H.; Azami, N.; Hushmandi, K.; Baradaran, B.; Hashmi, M.; Aref, A.R. Revealing the Role of miRNA-489 as a New Onco-Suppressor Factor in Different Cancers Based on Pre-Clinical and Clinical Evidence. Int. J. Biol. Macromol. 2021, 191, 727-737. [CrossRef] [PubMed]

193. Ashrafizadeh, M.; Mirzaei, S.; Gholami, M.H.; Hashemi, F.; Zabolian, A.; Raei, M.; Hushmandi, K.; Zarrabi, A.; Voelcker, N.H.; Aref, A.R. Hyaluronic acid-Based Nanoplatforms for Doxorubicin: A Review of Stimuli-Responsive Carriers, Co-Delivery And Resistance Suppression. Carbohydr. Polym. 2021, 272, 118491. [CrossRef] [PubMed]

194. Mirzaei, S.; Gholami, M.H.; Zabolian, A.; Saleki, H.; Farahani, M.V.; Hamzehlou, S.; Far, F.B.; Sharifzadeh, S.O.; Samarghandian, S.; Khan, H. Caffeic Acid and Its Derivatives as Potential Modulators of Oncogenic Molecular Pathways: New Hope in the Fight against Cancer. Pharmacol. Res. 2021, 171, 105759. [CrossRef]

195. Chopra, P.; Sethi, G.; Dastidar, S.G.; Ray, A. Polo-like Kinase Inhibitors: An Emerging Opportunity for Cancer Therapeutics. Expert Opin. Investig. Drugs 2010, 19, 27-43. [CrossRef]

196. Mishra, S.; Verma, S.S.; Rai, V.; Awasthee, N.; Chava, S.; Hui, K.M.; Kumar, A.P.; Challagundla, K.B.; Sethi, G.; Gupta, S.C. Long Non-Coding RNAs Are Emerging Targets of Phytochemicals for Cancer and Other Chronic Diseases. Cell Mol. Life Sci. 2019, 76, 1947-1966. [CrossRef] [PubMed]

197. Ashrafizaveh, S.; Ashrafizadeh, M.; Zarrabi, A.; Husmandi, K.; Zabolian, A.; Shahinozzaman, M.; Aref, A.R.; Hamblin, M.R.; Nabavi, N.; Crea, F. Long Non-Coding RNA in the Doxorubicin Resistance of Cancer Cells. Cancer Lett. 2021, 508, 104-114. [CrossRef] [PubMed]

198. Martinez-Contreras, R.; Cloutier, P.; Shkreta, L.; Fisette, J.F.; Revil, T.; Chabot, B. hnRNP Proteins and Splicing Control. Adv. Exp. Med. Biol. 2007, 623, 123-147. [CrossRef]

199. Gu, W.; Liu, W.; Shen, X.; Shi, Y.; Wang, L.; Liu, H. Emergence of Heterogeneous Nuclear Ribonucleoprotein A2/B1 vs. Loss of E-Cadherin: Their Reciprocal Immunoexpression Profiles in Human Pancreatic Cancer. Ann. Diagn. Pathol. 2013, 17, 14-17. [CrossRef]

200. Begines, P.; Sevilla-Horrillo, L.; Puerta, A.; Puckett, R.; Bayort, S.; Lagunes, I.; Maya, I.; Padrón, J.M.; López, Ó.; FernándezBolaños, J.G. Masked Phenolic-Selenium Conjugates: Potent and Selective Antiproliferative Agents Overcoming P-gp Resistance. Pharmaceuticals 2020, 13, 358. [CrossRef]

201. Gu, W.J.; Liu, H.L. Induction of Pancreatic Cancer Cell Apoptosis, Invasion, Migration, and Enhancement of Chemotherapy Sensitivity of Gemcitabine, 5-FU, and Oxaliplatin by hnRNP A2/B1 siRNA. Anticancer Drugs 2013, 24, 566-576. [CrossRef] [PubMed]

202. Goan, Y.G.; Zhou, B.; Hu, E.; Mi, S.; Yen, Y. Overexpression of Ribonucleotide Reductase as a Mechanism of Resistance to 2,2-Difluorodeoxycytidine in the Human KB Cancer Cell Line. Cancer Res. 1999, 59, 4204-4207. [PubMed]

203. Eriksson, S.; Martin, D.W.J. Ribonucleotide Reductase in Cultured Mouse Lymphoma Cells. Cell Cycle-Dependent Variation in the Activity of Subunit Protein M2. J. Biol. Chem. 1981, 256, 9436-9440. [CrossRef]

204. Duxbury, M.S.; Ito, H.; Zinner, M.J.; Ashley, S.W.; Whang, E.E. RNA Interference Targeting the M2 Subunit of Ribonucleotide Reductase Enhances Pancreatic Adenocarcinoma Chemosensitivity to Gemcitabine. Oncogene 2004, 23, 1539-1548. [CrossRef] [PubMed]

205. Réjiba, S.; Bigand, C.; Parmentier, C.; Hajri, A. Gemcitabine-Based Chemogene Therapy for Pancreatic Cancer Using AddCK::UMK GDEPT and TS/RR siRNA Strategies. Neoplasia 2009, 11, 637-650. [CrossRef] [PubMed]

206. Yang, L.; Kang, W.K. The Effect of HIF-1alpha siRNA on Growth and Chemosensitivity of MIA-Paca Cell Line. Yonsei Med. J. 2008, 49, 295-300. [CrossRef] [PubMed]

207. Al Hanjori, A.S.; Alshaer, W.; Anati, B.; Wehaibi, S.; Zihlif, M. Studying Antitumor Effects of siRNA Gene Silencing of Some Metabolic Genes in Pancreatic Ductal Adenocarcinoma. Curr.Mol. Pharmacol. 2020, 14, 604-619. [CrossRef]

208. Kami, K.; Doi, R.; Koizumi, M.; Toyoda, E.; Mori, T.; Ito, D.; Kawaguchi, Y.; Fujimoto, K.; Wada, M.; Miyatake, S.; et al. Downregulation of Survivin by siRNA Diminishes Radioresistance of Pancreatic Cancer Cells. Surgery 2005, 138, 299-305. [CrossRef]

209. Liu, W.S.; Yan, H.J.; Qin, R.Y.; Tian, R.; Wang, M.; Jiang, J.X.; Shen, M.; Shi, C.J. siRNA Directed against Survivin Enhances Pancreatic Cancer Cell Gemcitabine Chemosensitivity. Dig. Dis. Sci. 2009, 54, 89-96. [CrossRef]

210. Li, N.; Song, M.M.; Chen, X.H.; Liu, L.H.; Li, F.S. S100A4 siRNA Inhibits Human Pancreatic Cancer Cell Invasion in Vitro. Biomed. Environ. Sci. 2012, 25, 465-470. [CrossRef] 
211. Liu, D.; Zhang, Y.; Dang, C.; Ma, Q.; Lee, W.; Chen, W. siRNA Directed against TrkA Sensitizes Human Pancreatic Cancer Cells to Apoptosis Induced by Gemcitabine through an Inactivation of PI3K/Akt-Dependent Pathway. Oncol. Rep. 2007, 18, 673-677. [CrossRef]

212. Wang, W.; Wang, C.Y.; Dong, J.H.; Chen, X.; Zhang, M.; Zhao, G. Identification of Effective siRNA against K-Ras in Human Pancreatic Cancer Cell Line MiaPaCa-2 by siRNA Expression Cassette. World J. Gastroenterol. 2005, 11, 2026-2031. [CrossRef]

213. Chiu, Y.L.; Rana, T.M. RNAi in Human Cells: Basic Structural and Functional Features of Small Interfering RNA. Mol. Cell 2002, 10, 549-561. [CrossRef]

214. Chiu, Y.L.; Rana, T.M. siRNA Function in RNAi: A Chemical Modification Analysis. RNA 2003, 9, 1034-1048. [CrossRef] [PubMed]

215. Rana, T.M. Illuminating the Silence: Understanding the Structure and Function of Small RNAs. Nat. Rev. Mol. Cell Biol. 2007, 8, 23-36. [CrossRef]

216. Wang, Y.; Juranek, S.; Li, H.; Sheng, G.; Wardle, G.S.; Tuschl, T.; Patel, D.J. Nucleation, Propagation and Cleavage of Target RNAs in Ago Silencing Complexes. Nature 2009, 461, 754-761. [CrossRef] [PubMed]

217. Egli, M.; Manoharan, M. Re-Engineering RNA Molecules into Therapeutic Agents. Acc. Chem. Res. 2019, 52, 1036-1047. [CrossRef] [PubMed]

218. Setten, R.L.; Rossi, J.J.; Han, S. The Current State and Future Directions of RNAi-Based Therapeutics. Nat. Rev. Drug Discov. 2019, 18, 421-446. [CrossRef] [PubMed]

219. Khvorova, A.; Watts, J.K. The Chemical Evolution of Oligonucleotide Therapies of Clinical utility. Nat. Biotechnol. 2017, 35, 238-248. [CrossRef] [PubMed]

220. Ge, Q.; Dallas, A.; Ilves, H.; Shorenstein, J.; Behlke, M.A.; Johnston, B.H. Effects of Chemical Modification on the Potency, Serum Stability, and Immunostimulatory Properties of Short shRNAs. RNA 2010, 16, 118-130. [CrossRef]

221. Meade, B.R.; Gogoi, K.; Hamil, A.S.; Palm-Apergi, C.; Van Den Berg, A.; Hagopian, J.C.; Springer, A.D.; Eguchi, A.; Kacsinta, A.D.; Dowdy, C.F. Efficient Delivery of RNAi Prodrugs Containing Reversible Charge-Neutralizing Phosphotriester Backbone Modifications. Nat. Biotechnol. 2014, 32, 1256-1261. [CrossRef] [PubMed]

222. Bollu, A.; Hassan, M.K.; Dixit, M.; Sharma, N.K. The 2'-Caged-Tethered-siRNA Shows Light-Dependent Temporal Controlled RNAi Activity for GFP Gene into HEK293T Cells. Bioorg. Med. Chem. 2021, 30, 115932. [CrossRef] [PubMed]

223. Qiu, Y.; Lo, J.C.K.; Kwok, K.C.W.; Mason, A.J.; Lam, J.K.W. Modification of KL4 Peptide Revealed the Importance of Alpha-Helical Structure for Efficient siRNA Delivery. Nucleic Acid Ther. 2021, 31, 220-228. [CrossRef]

224. Irie, A.; Sato, K.; Hara, R.I.; Wada, T.; Shibasaki, F. An Artificial Cationic Oligosaccharide Combined with Phosphorothioate Linkages Strongly Improves siRNA Stability. Sci. Rep. 2020, 10, 14845. [CrossRef]

225. Davis, S.M.; Sousa, J.; Vangjeli, L.; Hassler, M.R.; Echeverria, D.; Knox, E.; Turanov, A.A.; Alterman, J.F.; Khvorova, A. 2'-O-Methyl at 20-Mer Guide Strand 3' Termini May Negatively Affect Target Silencing Activity of Fully Chemically Modified siRNA. Mol. Ther. Nucleic Acids 2020, 21, 266-277. [CrossRef]

226. Shinohara, F.; Oashi, T.; Harumoto, T.; Nishikawa, T.; Takayama, Y.; Miyagi, H.; Takahashi, Y.; Nakajima, T.; Sawada, T.; Koda, Y.; et al. siRNA Potency Enhancement via Chemical Modifications of Nucleotide Bases at the 5'-End of the siRNA Guide Strand. RNA 2021, 27, 163-173. [CrossRef] [PubMed]

227. Brechin, V.; Shinohara, F.; Saito, J.I.; Seitz, H.; Tomari, Y. Mechanistic Analysis of the Enhanced RNAi Activity by 6-mCEPh-Purine at the 5' End of the siRNA Guide Strand. RNA 2021, 27, 151-162. [CrossRef] [PubMed]

228. Rydzik, A.M.; Gottschling, D.; Simon, E.; Skronska-Wasek, W.; Rippmann, J.F.; Riether, D. Epigenetic Modification 6Methyladenosine Can Impact the Potency and Specificity of siRNA. Chembiochem 2021, 22, 491-495. [CrossRef]

229. Strand, M.S.; Krasnick, B.A.; Pan, H.; Zhang, X.; Bi, Y.; Brooks, C.; Wetzel, C.; Sankpal, N.; Fleming, T.; Goedegebuure, S.P.; et al. Precision Delivery of RAS-Inhibiting siRNA to KRAS Driven Cancer via Peptide-Based Nanoparticles. Oncotarget 2019, 10, 4761-4775. [CrossRef] [PubMed]

230. Wang, J.; Lu, Z.; Wang, J.; Cui, M.; Yeung, B.Z.; Cole, D.J.; Wientjes, M.G.; Au, J.L. Paclitaxel Tumor Priming Promotes Delivery and Transfection of Intravenous lipid-siRNA in Pancreatic Tumors. J. Control. Release 2015, 216, 103-110. [CrossRef]

231. Wang, J.; Lu, Z.; Yeung, B.Z.; Wientjes, M.G.; Cole, D.J.; Au, J.L. Tumor Priming Enhances siRNA Delivery and Transfection in Intraperitoneal Tumors. J. Control. Release 2014, 178, 79-85. [CrossRef] [PubMed]

232. McCarroll, J.A.; Sharbeen, G.; Kavallaris, M.; Phillips, P.A. The Use of Star Polymer Nanoparticles for the Delivery of siRNA to Mouse Orthotopic Pancreatic Tumor Models. Methods Mol. Biol. 2019, 1974, 329-353. [CrossRef] [PubMed]

233. Norouzi, P.; Amini, M.; Dinarvand, R.; Arefian, E.; Seyedjafari, E.; Atyabi, F. Co-Delivery of Gemcitabine Prodrug along with Anti NF-kB siRNA by Tri-Layer Micelles Can Increase Cytotoxicity, Uptake and Accumulation of the System in the Cancers. Mater. Sci. Eng. C Mater. Biol. Appl. 2020, 116, 111161. [CrossRef] [PubMed]

234. Wang, Z.; Wu, H.; Shi, H.; Wang, M.; Huang, C.; Jia, N. A Novel Multifunctional Biomimetic Au@ BSA Nanocarrier as a Potential siRNA Theranostic Nanoplatform. J. Mater. Chem. B 2016, 4, 2519-2526. [CrossRef] [PubMed]

235. Wang, Y.; Yang, C.; Hu, R.; Toh, H.T.; Liu, X.; Lin, G.; Yin, F.; Yoon, H.S.; Yong, K.T. Assembling Mn: ZnSe Quantum Dots-siRNA Nanoplexes for Gene Silencing in Tumor Cells. Biomater. Sci. 2015, 3, 192-202. [CrossRef]

236. Ramasamy, T.; Haidar, Z.S.; Tran, T.H.; Choi, J.Y.; Jeong, J.H.; Shin, B.S.; Choi, H.G.; Yong, C.S.; Kim, J.O. Layer-by-Layer Assembly of Liposomal Nanoparticles with PEGylated Polyelectrolytes Enhances Systemic Delivery of Multiple Anticancer Drugs. Acta Biomater. 2014, 10, 5116-5127. [CrossRef] 
237. Tran, T.H.; Ramasamy, T.; Choi, J.Y.; Nguyen, H.T.; Pham, T.T.; Jeong, J.H.; Ku, S.K.; Choi, H.G.; Yong, C.S.; Kim, J.O. TumorTargeting, pH-Sensitive Nanoparticles for Docetaxel Delivery to Drug-Resistant Cancer Cells. Int. J. Nanomed. 2015, 10, 5249. [CrossRef]

238. Moballegh Nasery, M.; Abadi, B.; Poormoghadam, D.; Zarrabi, A.; Keyhanvar, P.; Khanbabaei, H.; Ashrafizadeh, M.; Mohammadinejad, R.; Tavakol, S.; Sethi, G. Curcumin Delivery Mediated by Bio-Based Nanoparticles: A Review. Molecules 2020, 25, 689. [CrossRef]

239. Ashrafizadeh, M.; Ahmadi, Z.; Kotla, N.G.; Afshar, E.G.; Samarghandian, S.; Mandegary, A.; Pardakhty, A.; Mohammadinejad, R.; Sethi, G. Nanoparticles Targeting STATs in Cancer Therapy. Cells 2019, 8, 1158. [CrossRef]

240. Brand, T.M.; Iida, M.; Li, C.; Wheeler, D.L. The Nuclear Epidermal Growth Factor Receptor Signaling Network and Its Role in Cancer. Discov. Med. 2011, 12, 419.

241. Masuda, H.; Zhang, D.; Bartholomeusz, C.; Doihara, H.; Hortobagyi, G.N.; Ueno, N.T. Role of Epidermal Growth Factor Receptor in Breast Cancer. Breast Cancer Res. Treat 2012, 136, 331-345. [CrossRef]

242. Li, Z.; Zhao, R.; Wu, X.; Sun, Y.; Yao, M.; Li, J.; Xu, Y.; Gu, J. Identification and Characterization of a Novel Peptide Ligand of Epidermal Growth Factor Receptor for Targeted Delivery of Therapeutics. FASEB J. 2005, 19, 1978-1985. [CrossRef] [PubMed]

243. Schäfer, A.; Pahnke, A.; Schaffert, D.; Van Weerden, W.M.; De Ridder, C.M.A.; Rödl, W.; Vetter, A.; Spitzweg, C.; Kraaij, R.; Wagner, E. Disconnecting the Yin and Yang Relation of Epidermal Growth Factor Receptor (EGFR)-Mediated Delivery: A Fully Synthetic, EGFR-Targeted Gene Transfer System Avoiding Receptor Activation. Hum. Gene Ther. 2011, 22, 1463-1473. [CrossRef] [PubMed]

244. Zhu, Y.; Wu, F.; Gui, W.; Zhang, N.; Matro, E.; Zhu, L.; Eserberg, D.T.; Lin, X. A Positive Feedback Regulatory Loop Involving the lncRNA PVT1 and HIF-1 $\alpha$ in Pancreatic Cancer. J. Mol. Cell Biol. 2021, mjab042. [CrossRef] [PubMed]

245. Kang, G.; Hu, M.; Ren, H.; Wang, J.; Cheng, X.; Li, R.; Yuan, B.; Balan, Y.; Bai, Z.; Huang, H. VHH212 Nanobody Targeting the Hypoxia-Inducible Factor $1 \alpha$ Suppresses Angiogenesis and Potentiates Gemcitabine Therapy in Pancreatic Cancer in Vivo. Cancer Biol. Med. 2021, 18, 772-787. [CrossRef] [PubMed]

246. Lin, C.; Hu, Z.; Yuan, G.; Su, H.; Zeng, Y.; Guo, Z.; Zhong, F.; Jiang, K.; He, S. HIF1 $\alpha$-siRNA and Gemcitabine Combination-Based GE-11 Peptide Antibody-Targeted Nanomedicine for Enhanced Therapeutic Efficacy in Pancreatic Cancers. J. Drug Target 2019, 27, 797-805. [CrossRef] [PubMed]

247. Wang, Y.; Gao, F.; Jiang, X.; Zhao, X.; Wang, Y.; Kuai, Q.; Nie, G.; He, M.; Pan, Y.; Shi, W.; et al. Co-Delivery of Gemcitabine and Mcl-1 SiRNA via Cationic Liposome-Based System Enhances the Efficacy of Chemotherapy in Pancreatic Cancer. J. Biomed. Nanotechnol. 2019, 15, 966-978. [CrossRef]

248. Kanasty, R.; Dorkin, J.R.; Vegas, A.; Anderson, D. Delivery Materials for siRNA Therapeutics. Nat. Mater. 2013, 12, 967-977. [CrossRef]

249. Oh, Y.K.; Park, T.G. siRNA Delivery Systems for Cancer Treatment. Adv. Drug Deliv. Rev. 2009, 61, 850-862. [CrossRef]

250. Li, J.; Huang, L. Targeted Delivery of RNAi Therapeutics for Cancer Therapy. Nanomedicine 2010, 5, 1483-1486. [CrossRef]

251. Wang, H.; Wu, Y.; Zhao, R.; Nie, G. Engineering the Assemblies of Biomaterial Nanocarriers for Delivery of Multiple Theranostic Agents with Enhanced Antitumor Efficacy. Adv. Mater. 2013, 25, 1616-1622. [CrossRef] [PubMed]

252. Aigner, A. Nonviral in Vivo Delivery of Therapeutic Small Interfering RNAs. Curr. Opin. Mol. Ther. $2007,9,345-352$.

253. Mandal, B.; Bhattacharjee, H.; Mittal, N.; Sah, H.; Balabathula, P.; Thoma, L.A.; Wood, G.C. Core-Shell-Type Lipid-Polymer Hybrid Nanoparticles as a Drug Delivery Platform. Nanomedicine 2013, 9, 474-491. [CrossRef]

254. Raemdonck, K.; Braeckmans, K.; Demeester, J.; De Smedt, S.C. Merging the Best of Both Worlds: Hybrid Lipid-Enveloped Matrix Nanocomposites in Drug Delivery. Chem. Soc. Rev. 2014, 43, 444-472. [CrossRef] [PubMed]

255. Zhao, X.; Li, F.; Li, Y.; Wang, H.; Ren, H.; Chen, J.; Nie, G.; Hao, J. Co-Delivery of HIF1 $\alpha$ siRNA and Gemcitabine via Biocompatible Lipid-Polymer Hybrid Nanoparticles for Effective Treatment of Pancreatic Cancer. Biomaterials 2015, 46, 13-25. [CrossRef]

256. Matsumura, Y.; Maeda, H. A New Concept for Macromolecular Therapeutics in Cancer Chemotherapy: Mechanism of Tumoritropic Accumulation of Proteins and the Antitumor Agent Smancs. Cancer Res. 1986, 46, 6387-6392.

257. Cabral, H.; Matsumoto, Y.; Mizuno, K.; Chen, Q.; Murakami, M.; Kimura, M.; Terada, Y.; Kano, M.R.; Miyazono, K.; Uesaka, M. Accumulation of Sub-100 nm Polymeric Micelles in Poorly Permeable Tumours Depends on Size. Nat. Nanotechnol. 2011, 6 , 815-823. [CrossRef] [PubMed]

258. Kataoka, K.; Harada, A.; Nagasaki, Y. Block Copolymer Micelles for Drug Delivery: Design, Characterization and Biological Significance. Adv. Drug Deliv. Rev. 2012, 64, 37-48. [CrossRef]

259. Wagner, E. Polymers for siRNA Delivery: Inspired by Viruses to be Targeted, Dynamic, and Precise. Acc. Chem. Res. 2012, 45, 1005-1013. [CrossRef]

260. Bertrand, N.; Wu, J.; Xu, X.; Kamaly, N.; Farokhzad, O.C. Cancer Nanotechnology: The Impact of Passive and Active Targeting in the Era of Modern Cancer Biology. Adv. Drug Deliv. Rev. 2014, 66, 2-25. [CrossRef]

261. Min, H.S.; Kim, H.J.; Ahn, J.; Naito, M.; Hayashi, K.; Toh, K.; Kim, B.S.; Matsumura, Y.; Kwon, I.C.; Miyata, K.; et al. Tuned Density of Anti-Tissue Factor Antibody Fragment onto siRNA-Loaded Polyion Complex Micelles for Optimizing Targetability into Pancreatic Cancer Cells. Biomacromolecules 2018, 19, 2320-2329. [CrossRef]

262. Kashyap, D.; Tuli, H.S.; Yerer, M.B.; Sharma, A.; Sak, K.; Srivastava, S.; Pandey, A.; Garg, V.K.; Sethi, G.; Bishayee, A. Natural Product-Based Nanoformulations for Cancer Therapy: Opportunities and Challenges. Semin. Cancer Biol. 2021, 69, 5-23. [CrossRef] 
263. Chen, C.K.; Law, W.C.; Aalinkeel, R.; Nair, B.; Kopwitthaya, A.; Mahajan, S.D.; Reynolds, J.L.; Zou, J.; Schwartz, S.A.; Prasad, P.N. Well-Defined Degradable Cationic Polylactide as Nanocarrier for the Delivery of siRNA to Silence Angiogenesis in Prostate Cancer. Adv. Healthc. Mater. 2012, 1, 751-761. [CrossRef]

264. Repasky, G.A.; Chenette, E.J.; Der, C.J. Renewing the Conspiracy Theory Debate: Does Raf Function Alone to Mediate Ras Oncogenesis? Trends Cell Biol. 2004, 14, 639-647. [CrossRef] [PubMed]

265. Campbell, S.L.; Khosravi-Far, R.; Rossman, K.L.; Clark, G.J.; Der, C.J. Increasing Complexity of Ras Signaling. Oncogene 1998, 17, 1395-1413. [CrossRef]

266. Barbacid, M.M.M.; Barbacid, M. Ras Oncogenes: The First 30 Years. Nat. Rev. Cancer 2003, 3, 459-465. [CrossRef]

267. Hanahan, D.; Weinberg, R.A. The Hallmarks of Cancer. Cell 2000, 100, 57-70. [CrossRef]

268. Lin, G.; Chen, C.K.; Yin, F.; Yang, C.; Tian, J.; Chen, T.; Xu, G.; He, C.; Lin, M.C.; Wang, J.; et al. Biodegradable Nanoparticles as siRNA Carriers for in Vivo Gene Silencing and Pancreatic Cancer Therapy. J. Mater. Chem. B 2017, 5, 3327-3337. [CrossRef]

269. Sugahara, K.N.; Teesalu, T.; Karmali, P.P.; Kotamraju, V.R.; Agemy, L.; Girard, O.M.; Hanahan, D.; Mattrey, R.F.; Ruoslahti, E. Tissue-Penetrating Delivery of Compounds and Nanoparticles into Tumors. Cancer Cell 2009, 16, 510-520. [CrossRef] [PubMed]

270. Yang, D.; Wang, H.; Sun, C.; Zhao, H.; Hu, K.; Qin, W.; Ma, R.; Yin, F.; Qin, X.; Zhang, Q.; et al. Development of a High Quantum Yield Dye for Tumour Imaging. Chem. Sci. 2017, 8, 6322-6326. [CrossRef] [PubMed]

271. Huang, Y.; Li, X.; Sha, H.; Zhang, L.; Bian, X.; Han, X.; Liu, B. sTRAIL-iRGD is a Promising Therapeutic Agent for Gastric Cancer Treatment. Sci. Rep. 2017, 7, 579. [CrossRef]

272. Lo, J.H.; Hao, L.; Muzumdar, M.D.; Raghavan, S.; Kwon, E.J.; Pulver, E.M.; Hsu, F.; Aguirre, A.J.; Wolpin, B.M.; Fuchs, C.S.; et al. iRGD-Guided Tumor-Penetrating Nanocomplexes for Therapeutic siRNA Delivery to Pancreatic Cancer. Mol. Cancer Ther. 2018, 17, 2377-2388. [CrossRef]

273. Kim, H.A.; Nam, K.; Kim, S.W. Tumor Targeting RGD Conjugated Bio-Reducible Polymer for VEGF siRNA Expressing Plasmid Delivery. Biomaterials 2014, 35, 7543-7552. [CrossRef] [PubMed]

274. Xie, Y.; Hang, Y.; Wang, Y.; Sleightholm, R.; Prajapati, D.R.; Bader, J.; Yu, A.; Tang, W.; Jaramillo, L.; Li, J.; et al. Stromal Modulation and Treatment of Metastatic Pancreatic Cancer with Local Intraperitoneal Triple miRNA/siRNA Nanotherapy. ACS Nano 2020, 14, 255-271. [CrossRef] [PubMed]

275. Ma, Z.; Wang, L.Z.; Cheng, J.T.; Lam, W.S.T.; Ma, X.; Xiang, X.; Wong, A.L.; Goh, B.C.; Gong, Q.; Sethi, G.; et al. Targeting Hypoxia-Inducible Factor-1-Mediated Metastasis for Cancer Therapy. Antioxid. Redox. Signal 2021, 34, 1484-1497. [CrossRef] [PubMed]

276. Zhen, Q.; Zhang, Y.; Gao, L.; Wang, R.; Chu, W.; Zhao, X.; Li, Z.; Li, H.; Zhang, B.; Lv, B.; et al. EPAS1 Promotes Peritoneal Carcinomatosis of Non-Small-Cell Lung Cancer by Enhancing Mesothelial-Mesenchymal Transition. Strahlenther. Onkol. 2020, 197, 141-149. [CrossRef]

277. Islam, F.; Gopalan, V.; Law, S.; Lam, A.K.; Pillai, S. Molecular Deregulation of EPAS1 in the Pathogenesis of Esophageal Squamous Cell Carcinoma. Front. Oncol. 2020, 10, 1534. [CrossRef] [PubMed]

278. Pan, X.; Zhu, Q.; Sun, Y.; Li, L.; Zhu, Y.; Zhao, Z.; Zuo, J.; Fang, W.; Li, K. PLGA/Poloxamer Nanoparticles Loaded with EPAS1 siRNA for the Treatment of Pancreatic Cancer in Vitro and in Vivo. Int. J. Mol. Med. 2015, 35, 995-1002. [CrossRef] [PubMed]

279. Wittenberger, T.; Schaller, H.C.; Hellebrand, S. An Expressed Sequence Tag (EST) Data Mining Strategy Succeeding in the Discovery of New G-Protein Coupled Receptors. J. Mol. Biol. 2001, 307, 799-813. [CrossRef]

280. Wang, L.; Zhou, W.; Zhong, Y.; Huo, Y.; Fan, P.; Zhan, S.; Xiao, J.; Jin, X.; Gou, S.; Yin, T. Overexpression of G Protein-Coupled Receptor GPR87 Promotes Pancreatic Cancer Aggressiveness and Activates NF-kB Signaling Pathway. Mol. Cancer. 2017, 16, 61. [CrossRef] [PubMed]

281. Zhang, Y.; Scoumanne, A.; Chen, X. G Protein-Coupled Receptor 87: A Promising Opportunity for Cancer Drug Discovery. Mol. Cell. Pharmacol. 2010, 2, 111.

282. Glatt, S.; Halbauer, D.; Heindl, S.; Wernitznig, A.; Kozina, D.; Su, K.C.; Puri, C.; Garin-Chesa, P.; Sommergruber, W. hGPR87 Contributes to Viability of Human Tumor Cells. Int. J. Cancer 2008, 122, 2008-2016. [CrossRef] [PubMed]

283. Dauer, P.; Sharma, N.S.; Gupta, V.K.; Nomura, A.; Dudeja, V.; Saluja, A.; Banerjee, S. GRP78-Mediated Antioxidant Response and ABC Transporter Activity Confers Chemoresistance to Pancreatic Cancer Cells. Mol. Oncol. 2018, 12, 1498-1512. [CrossRef] [PubMed]

284. Gopal, U.; Mowery, Y.; Young, K.; Pizzo, S.V. Targeting Cell Surface GRP78 Enhances Pancreatic Cancer Radiosensitivity through YAP/TAZ Protein Signaling. J. Biol. Chem. 2019, 294, 13939-13952. [CrossRef]

285. Ceylan, S.; Bahadori, F.; Akbas, F. Engineering of siRNA Loaded PLGA Nano-Particles for Highly Efficient Silencing of GPR87 Gene as a Target for Pancreatic Cancer Treatment. Pharm. Dev. Technol. 2020, 25, 855-864. [CrossRef] [PubMed]

286. Zeng, L.; Li, J.; Wang, Y.; Qian, C.; Chen, Y.; Zhang, Q.; Wu, W.; Lin, Z.; Liang, J.; Shuai, X.; et al. Combination of siRNA-Directed Kras Oncogene Silencing and Arsenic-Induced Apoptosis Using a Nanomedicine Strategy for the Effective Treatment of Pancreatic Cancer. Nanomedicine 2014, 10, 463-472. [CrossRef] [PubMed]

287. Ramot, Y.; Rotkopf, S.; Gabai, R.M.; Zorde Khvalevsky, E.; Muravnik, S.; Marzoli, G.A.; Domb, A.J.; Shemi, A.; Nyska, A. Preclinical Safety Evaluation in Rats of a Polymeric Matrix Containing an siRNA Drug Used as a Local and Prolonged Delivery System for Pancreatic Cancer Therapy. Toxicol. Pathol. 2016, 44, 856-865. [CrossRef] 
288. Pittella, F.; Zhang, M.; Lee, Y.; Kim, H.J.; Tockary, T.; Osada, K.; Ishii, T.; Miyata, K.; Nishiyama, N.; Kataoka, K. Enhanced Endosomal Escape of siRNA-Incorporating Hybrid Nanoparticles from Calcium Phosphate and PEG-Block Charge-Conversional Polymer for Efficient Gene Knockdown with Negligible Cytotoxicity. Biomaterials 2011, 32, 3106-3114. [CrossRef]

289. Lin, G.; Hu, R.; Law, W.C.; Chen, C.K.; Wang, Y.; Li Chin, H.; Nguyen, Q.T.; Lai, C.K.; Yoon, H.S.; Wang, X.; et al. Biodegradable Nanocapsules as siRNA Carriers for Mutant K-Ras gene Silencing of Human Pancreatic Carcinoma Cells. Small 2013, 9, $2757-2763$. [CrossRef]

290. Kim, H.J.; Oba, M.; Pittella, F.; Nomoto, T.; Cabral, H.; Matsumoto, Y.; Miyata, K.; Nishiyama, N.; Kataoka, K. PEG-Detachable Cationic Polyaspartamide Derivatives Bearing Stearoyl Moieties for Systemic siRNA Delivery toward Subcutaneous BxPC3 Pancreatic Tumor. J. Drug Target 2012, 20, 33-42. [CrossRef]

291. Yin, F.; Lan, R.; Zhang, X.; Zhu, L.; Chen, F.; Xu, Z.; Liu, Y.; Ye, T.; Sun, H.; Lu, F.; et al. LSD1 Regulates Pluripotency of Embryonic Stem/Carcinoma Cells through Histone Deacetylase 1-Mediated Deacetylation of Histone H4 at Lysine 16. Mol. Cell Biol. 2014, 34, 158-179. [CrossRef] [PubMed]

292. Chen, Y.; Wang, L.; Shi, J. Two-Dimensional Non-Carbonaceous Materials-Enabled Efficient Photothermal Cancer Therapy. Nano Today 2016, 11, 292-308. [CrossRef]

293. Izadi, S.; Moslehi, A.; Kheiry, H.; Karoon Kiani, F.; Ahmadi, A.; Masjedi, A.; Ghani, S.; Rafiee, B.; Karpisheh, V.; Hajizadeh, F.; et al. Codelivery of HIF-1 $\alpha$ siRNA and Dinaciclib by Carboxylated Graphene Oxide-Trimethyl Chitosan-Hyaluronate Nanoparticles Significantly Suppresses Cancer Cell progression. Pharm. Res. 2020, 37, 196. [CrossRef] [PubMed]

294. Liu, J.; Cui, L.; Losic, D. Graphene and Graphene Oxide as New Nanocarriers for Drug Delivery Applications. Acta Biomater. 2013, 9, 9243-9257. [CrossRef]

295. Yin, F.; Hu, K.; Chen, Y.; Yu, M.; Wang, D.; Wang, Q.; Yong, K.T.; Lu, F.; Liang, Y.; Li, Z. SiRNA Delivery with PEGylated Graphene Oxide Nanosheets for Combined Photothermal and Genetherapy for Pancreatic Cancer. Theranostics 2017, 7, 1133-1148. [CrossRef]

296. Zhang, X.; Zhang, Z.; Xu, X.; Li, Y.; Li, Y.; Jian, Y.; Gu, Z. Bioinspired Therapeutic Dendrimers as Efficient Peptide Drugs Based on Supramolecular Interactions for Tumor Inhibition. Angew. Chem. Int. Ed. Engl. 2015, 127, 4363-4368. [CrossRef]

297. Zhang, Z.; Zhang, X.; Xu, X.; Li, Y.; Li, Y.; Zhong, D.; He, Y.; Gu, Z. Virus-Inspired Mimics Based on Dendritic Lipopeptides for Efficient Tumor-Specific Infection and Systemic Drug Delivery. Adv. Funct. Mater. 2015, 25, 5250-5260. [CrossRef]

298. Dong, Y.; Chen, Y.; Zhu, D.; Shi, K.; Ma, C.; Zhang, W.; Rocchi, P.; Jiang, L.; Liu, X. Self-Assembly of Amphiphilic Phospholipid Peptide Dendrimer-Based Nanovectors for Effective Delivery of siRNA Therapeutics in Prostate Cancer Therapy. J. Control. Release 2020, 322, 416-425. [CrossRef]

299. Amreddy, N.; Ahmed, R.A.; Munshi, A.; Ramesh, R. Tumor-Targeted Dendrimer Nanoparticles for Combinatorial Delivery of siRNA and Chemotherapy for Cancer Treatment. Methods Mol. Biol. 2020, 2059, 167-189. [CrossRef]

300. Li, Y.; Wang, H.; Wang, K.; Hu, Q.; Yao, Q.; Shen, Y.; Yu, G.; Tang, G. Targeted Co-Delivery of PTX and TR3 siRNA by PTP Peptide Modified Dendrimer for the Treatment of Pancreatic Cancer. Small 2017, 13, 1602697. [CrossRef]

301. Vyas, D.; Lopez-Hisijos, N.; Gandhi, S.; El-Dakdouki, M.; Basson, M.D.; Walsh, M.F.; Huang, X.; Vyas, A.K.; Chaturvedi, L.S. Doxorubicin-Hyaluronan Conjugated Super-Paramagnetic Iron Oxide Nanoparticles (DOX-HA-SPION) Enhanced Cytoplasmic Uptake of Doxorubicin and Modulated Apoptosis, IL-6 Release and NF-kappaB Activity in Human MDA-MB-231 Breast Cancer Cells. J Nanosci. Nanotechnol. 2015, 15, 6413-6422. [CrossRef] [PubMed]

302. Hamzian, N.; Hashemi, M.; Ghorbani, M.; Aledavood, S.A.; Ramezani, M.; Bahreyni Toosi, M.H. In-Vitro Study of Multifunctional PLGA-SPION Nanoparticles Loaded with Gemcitabine as Radiosensitizer Used in Radiotherapy. Iran J. Pharm. Res. 2019, 18, 1694-1703. [CrossRef] [PubMed]

303. Hajizadeh, F.; Moghadaszadeh Ardebili, S.; Baghi Moornani, M.; Masjedi, A.; Atyabi, F.; Kiani, M.; Namdar, A.; Karpisheh, V.; Izadi, S.; Baradaran, B.; et al. Silencing of HIF-1 $\alpha /$ CD73 Axis by siRNA-Loaded TAT-Chitosan-Spion Nanoparticles Robustly Blocks Cancer Cell Progression. Eur. J. Pharmacol. 2020, 882, 173235. [CrossRef] [PubMed]

304. Li, J.; Wang, R.; Schweickert, P.G.; Karki, A.; Yang, Y.; Kong, Y.; Ahmad, N.; Konieczny, S.F.; Liu, X. Plk1 Inhibition Enhances the Efficacy of Gemcitabine in Human Pancreatic Cancer. Cell Cycle 2016, 15, 711-719. [CrossRef]

305. Song, B.; Liu, X.S.; Rice, S.J.; Kuang, S.; Elzey, B.D.; Konieczny, S.F.; Ratliff, T.L.; Hazbun, T.; Chiorean, E.G.; Liu, X. Plk1 Phosphorylation of orc2 and hbo1 Contributes to Gemcitabine Resistance in Pancreatic Cancer. Mol. Cancer Ther. 2013, 12, 58-68. [CrossRef]

306. Chen, B.; Zhu, A.; Tian, L.; Xin, Y.; Liu, X.; Peng, Y.; Zhang, J.; Miao, Y.; Wei, J. miR-23a Suppresses Pancreatic Cancer Cell Progression by Inhibiting PLK-1 Expression. Mol. Med. Rep. 2018, 18, 105-112. [CrossRef]

307. Mahajan, U.M.; Teller, S.; Sendler, M.; Palankar, R.; van den Brandt, C.; Schwaiger, T.; Kühn, J.P.; Ribback, S.; Glöckl, G.; Evert, M.; et al. Tumour-Specific Delivery of siRNA-Coupled Superparamagnetic Iron Oxide Nanoparticles, Targeted against PLK1, Stops Progression of Pancreatic Cancer. Gut 2016, 65, 1838-1849. [CrossRef]

308. Ghosh, P.; Han, G.; De, M.; Kim, C.K.; Rotello, V.M. Gold Nanoparticles in Delivery Applications. Adv. Drug Deliv. Rev. 2008, 60, 1307-1315. [CrossRef]

309. Ding, Y.; Jiang, Z.; Saha, K.; Kim, C.S.; Kim, S.T.; Landis, R.F.; Rotello, V.M. Gold Nanoparticles for Nucleic Acid Delivery. Mol. Ther. 2014, 22, 1075-1083. [CrossRef] [PubMed]

310. Zhao, Y.; Chen, Z.; Chen, Y.; Xu, J.; Li, J.; Jiang, X. Synergy of Non-Antibiotic Drugs and Pyrimidinethiol on Gold Nanoparticles against Superbugs. J. Am. Chem. Soc. 2013, 135, 12940-12943. [CrossRef] 
311. Zhao, Y.; Ye, C.; Liu, W.; Chen, R.; Jiang, X. Tuning the Composition of AuPt Bimetallic Nanoparticles for Antibacterial Application. Angew. Chem. Int. Ed. Engl. 2014, 53, 8127-8131. [CrossRef] [PubMed]

312. Xianyu, Y.; Wang, Z.; Jiang, X. A Plasmonic Nanosensor for Immunoassay via Enzyme-Triggered Click Chemistry. ACS Nano 2014, 8, 12741-12747. [CrossRef] [PubMed]

313. Xianyu, Y.; Xie, Y.; Wang, N.; Wang, Z.; Jiang, X. A Dispersion-Dominated Chromogenic Strategy for Colorimetric Sensing of Glutathione at the Nanomolar Level Using Gold Nanoparticles. Small 2015, 11, 5510-5514. [CrossRef]

314. Cutler, J.I.; Auyeung, E.; Mirkin, C.A. Spherical Nucleic Acids. J. Am. Chem. Soc. 2012, 134, 1376-1391. [CrossRef] [PubMed]

315. Jensen, S.A.; Day, E.S.; Ko, C.H.; Hurley, L.A.; Luciano, J.P.; Kouri, F.M.; Merkel, T.J.; Luthi, A.J.; Patel, P.C.; Cutler, J.I.; et al. Spherical Nucleic Acid Nanoparticle Conjugates as an RNAi-Based Therapy for Glioblastoma. Sci. Transl. Med. 2013, 5, 209 ra152. [CrossRef] [PubMed]

316. Randeria, P.S.; Seeger, M.A.; Wang, X.Q.; Wilson, H.; Shipp, D.; Mirkin, C.A.; Paller, A.S. siRNA-Based Spherical Nucleic Acids Reverse Impaired Wound Healing in Diabetic Mice by Ganglioside GM3 Synthase Knockdown. Proc. Natl. Acad. Sci. USA 2015, 112, 5573-5578. [CrossRef] [PubMed]

317. Pierucci, D.; Cicconi, S.; Bonini, P.; Ferrelli, F.; Pastore, D.; Matteucci, C.; Marselli, L.; Marchetti, P.; Ris, F.; Halban, P.; et al. NGF-Withdrawal Induces Apoptosis in Pancreatic Beta Cells in Vitro. Diabetologia 2001, 44, 1281-1295. [CrossRef]

318. Jiang, J.; Bai, J.; Qin, T.; Wang, Z.; Han, L. NGF from Pancreatic Stellate Cells Induces Pancreatic Cancer Proliferation and Invasion by PI3K/AKT/GSK Signal Pathway. J. Cell Mol. Med. 2020, 24, 5901-5910. [CrossRef]

319. Lei, Y.; Tang, L.; Xie, Y.; Xianyu, Y.; Zhang, L.; Wang, P.; Hamada, Y.; Jiang, K.; Zheng, W.; Jiang, X. Gold Nanoclusters-Assisted Delivery of NGF siRNA for Effective Treatment of Pancreatic Cancer. Nat. Commun. 2017, 8, 15130. [CrossRef] [PubMed]

320. Vallet-Regí, M.; Balas, F.; Arcos, D. Mesoporous Materials for Drug Delivery. Angew. Chem. Int. Ed. Engl. 2007, 46, 7548-7558. [CrossRef]

321. Slowing, I.I.; Vivero-Escoto, J.L.; Wu, C.W.; Lin, V.S. Mesoporous Silica Nanoparticles as Controlled Release Drug Delivery and Gene Transfection Carriers. Adv. Drug Deliv. Rev. 2008, 60, 1278-1288. [CrossRef]

322. Borm, P.; Klaessig, F.C.; Landry, T.D.; Moudgil, B.; Pauluhn, J.; Thomas, K.; Trottier, R.; Wood, S. Research Strategies for Safety Evaluation of Nanomaterials, Part V: Role of Dissolution in Biological Fate and Effects of Nanoscale Particles. Toxicol. Sci. 2006, 90, 23-32. [CrossRef]

323. Finnie, K.S.; Waller, D.J.; Perret, F.L.; Krause-Heuer, A.M.; Lin, H.Q.; Hanna, J.V.; Barbé, C.J. Biodegradability of Sol-Gel Silica Microparticles for Drug Delivery. J. Sol-Gel Sci. Technol. 2009, 49, 12-18. [CrossRef]

324. Wang, Y.; Xie, Y.; Kilchrist, K.V.; Li, J.; Duvall, C.L.; Oupický, D. Endosomolytic and Tumor-Penetrating Mesoporous Silica Nanoparticles for siRNA/miRNA Combination Cancer Therapy. ACS Appl. Mater. Interfaces 2020, 12, 4308-4322. [CrossRef]

325. Hanafi-Bojd, M.Y.; Ansari, L.; Malaekeh-Nikouei, B. Codelivery of Anticancer Drugs and siRNA by Mesoporous Silica Nanoparticles. Ther. Deliv. 2016, 7, 649-655. [CrossRef] [PubMed]

326. Bhattarai, S.R.; Muthuswamy, E.; Wani, A.; Brichacek, M.; Castañeda, A.L.; Brock, S.L.; Oupicky, D. Enhanced Gene and siRNA Delivery by Polycation-Modified Mesoporous Silica Nanoparticles Loaded with Chloroquine. Pharm. Res. 2010, 27, $2556-2568$. [CrossRef] [PubMed]

327. Xia, T.; Kovochich, M.; Liong, M.; Meng, H.; Kabehie, S.; George, S.; Zink, J.I.; Nel, A.E. Polyethyleneimine Coating Enhances the Cellular Uptake of Mesoporous Silica Nanoparticles and Allows Safe Delivery of siRNA and DNA Constructs. ACS Nano 2009, 3 , 3273-3286. [CrossRef]

328. Devroe, E.; Silver, P.A. Retrovirus-Delivered siRNA. BMC Biotechnol. 2002, 2, 15. [CrossRef]

329. Barton, G.M.; Medzhitov, R. Retroviral Delivery of Small Interfering RNA into Primary Cells. Proc. Natl. Acad. Sci. USA 2002, 99, 14943-14945. [CrossRef]

330. Xia, H.; Mao, Q.; Paulson, H.L.; Davidson, B.L. siRNA-Mediated Gene Silencing in Vitro and in Vivo. Nat. Biotechnol. 2002, 20, 1006-1010. [CrossRef] [PubMed]

331. Miller, A.D. Human Gene Therapy Comes of Age. Nature 1992, 357, 455-460. [CrossRef] [PubMed]

332. Berkner, K.L. Development of Adenovirus Vectors for the Expression of Heterologous Genes. Biotechniques 1988, 6, 616-629. [PubMed]

333. He, T.C.; Da Costa, L.T.; Yu, J.; Kinzler, K.W.; Vogelstein, B. A Simplified System for Generating Recombinant Adenoviruses. Proc. Natl. Acad. Sci. USA 1998, 95, 2509-2514. [CrossRef] [PubMed]

334. Chen, L.M.; Le, H.Y.; Qin, R.Y.; Kumar, M.; Du, Z.Y.; Xia, R.J.; Deng, J. Reversal of the Phenotype by K-rasval12 Silencing Mediated by Adenovirus-Delivered siRNA in Human Pancreatic Cancer Cell Line Panc-1. World J. Gastroenterol. 2005, 11, 831. [CrossRef]

335. Akgul, C.; Turner, P.; White, M.; Edwards, S. Functional Analysis of the Human MCL-1 Gene. Cell Mol. Life Sci. $2000,57,684-691$. [CrossRef] [PubMed]

336. Miyamoto, Y.; Hosotani, R.; Wada, M.; Lee, J.U.; Koshiba, T.; Fujimoto, K.; Tsuji, S.; Nakajima, S.; Doi, R.; Kato, M. Immunohistochemical Analysis of Bcl-2, Bax, Bcl-X, and Mcl-1 Expression in Pancreatic Cancers. Oncology 1999, 56, 73-82. [CrossRef] [PubMed]

337. Boucher, M.J.; Morisset, J.; Vachon, P.H.; Reed, J.C.; Lainé, J.; Rivard, N. MEK/ERK Signaling Pathway Regulates the Expression of Bcl-2, Bcl-XL, and Mcl-1 and Promotes Survival of Human Pancreatic Cancer Cells. J. Cell Biochem. 2000, 79, 355-369. [CrossRef]

338. Guoan, X.; Hanning, W.; Kaiyun, C.; Hao, L. Adenovirus-Mediated siRNA Targeting Mcl-1 Gene Increases Radiosensitivity of Pancreatic Carcinoma Cells in Vitro and in Vivo. Surgery 2010, 147, 553-561. [CrossRef] 
339. Guo, J.; Gao, J.; Li, Z.; Gong, Y.; Man, X.; Jin, J.; Wu, H. Adenovirus Vector-Mediated Gli1 siRNA Induces Growth Inhibition and Apoptosis in Human Pancreatic Cancer with Smo-Dependent or Smo-Independent Hh Pathway Activation in Vitro and in Vivo. Cancer Lett. 2013, 339, 185-194. [CrossRef] [PubMed]

340. Anderson, T.; Hu, R.; Yang, C.; Yoon, H.S.; Yong, K.T. Pancreatic Cancer Gene Therapy Using an siRNA-Functionalized Single Walled Carbon Nanotubes (SWNTs) Nanoplex. Biomater. Sci. 2014, 2, 1244-1253. [CrossRef] 